\title{
Sôbre algumas Tubificidae do Brasil
}

\author{
POR \\ Ernesto Marcus
}

(Com 12 estampas)

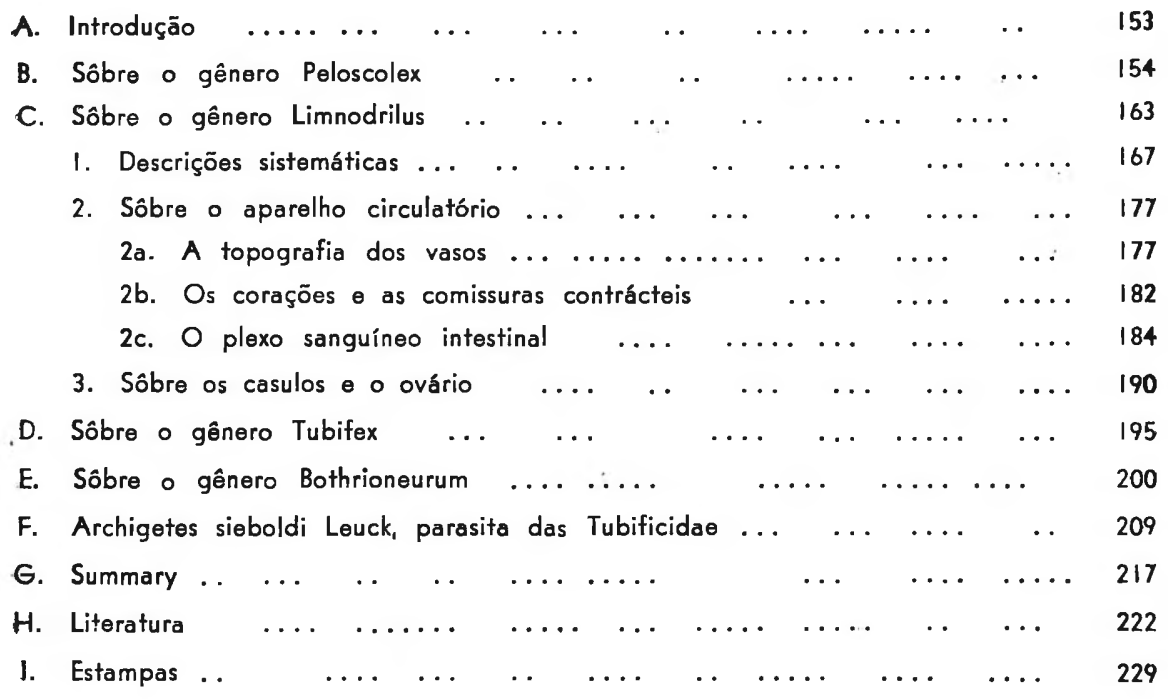

\section{A. Introdução}

Estudando juntamente com a minha esposa, Exma. Sra. D. EVELINE DU BOIS-REYMOND MARCUS, os Oligochaeta límnicos (Limicola) brasileiros، principalmente os de São Paulo, apresento aqui os primeiros resultados relativos a algumas espécies das Tubificidae. Vermes dessa família, p. e., reoresentantes dos gêneros $T u b i f e x$ e Limnodrilus, servem como objetos próprios para a observação da circulação e respiração nos exercícios práticos do curso de fisiologia comparativa, de modo que, sendo êles assim utilizados pelo meu colega, Prof. Dr. Paulo Sawaya, era de desejar-se a sua classificação. Ao Sr. Dr. Michel Pedro Sawaya, Licenciado em Ciên- 
cias Naturais, agradeço a revisão linguística do manuscrito, assim como o auxilio nas provas.

A última resenha dos Oligoquetos brasileiros (Michaelsen 1927) não contem nenhuma espécie das Tubificidas. Tal fato demonstra apenas que o grupo ainda não foi estudado no país, visto que a família abrange, pelo menos, I20 espécies, das quais várias foram encontradas nas Indias Orientais, o que revela serem adatadas às temperaturas elevadas.

A ausência de estudos precedentes sôbre Tubificidae brasileiras obrigava a recorrer, em cada caso, às monografias de Beddard (1895) e de Michaelsen (1900). Embora muito pobre em figuras a primeira e quasi destituida de tais a segunda, são essas obras indispensáveis para a determinação dos Limicola e, graças ao grande pioneiro da Zoologia em São Paulo, Hermann von thering, figuram na biblioteca do Museu Paulista de Zoologia (da Secretaria de Agricultura), a cujo Diretor atual, Dr. Olivério Mário de Oliveira Pinto, agradeço por nô-las ter emprestado.

Por outro lado, faltava-nos o "Sistema e Morfologia dos Oligoquetos" de F. Vejdovsky (1884), obra cuja beleza lembro da minha atividade anterior na Europa. Essa e outras lacunas bibliográficas, que os especialistas hão de notar no trabalho presente, pudemos, pelo menos em parte, preencher pela monografia de J. Stephenson (1930), que prima na segurança das informações, clarissimamente comunicadas.

Com respeito aos Terricola brasileiros, já existem vários trabalhos, p. e., os de Michaelsen (1918; 1925; 1927, etc.), de Cernosvitov (1935) e outros. Das duas famílias dos Limicola, cuja literatura estudámos por enquanto, das Naididae e Tubificidae, conhecem-se do Brasil apenas duas Naididas, A u lophorus borellii (Michaelsen 1900, p. 522; Moreira 1903, p. 129) e Schmardaella lutzi (Michaelsen 1926, p. 100; 1926a, p. 232, 241; Lutz 1927). Sôbre Limicola. sulamericanos, em geral, informam, entre outros: Beddard (1896, Chile, Argentina); Cernosvitov (1936; 1937. Argentina); Cordero (1931, Uruguay); Michaelsen (1905, Paraguay); Stephenson (1931, Paraguay); Piguet (1928, Perú): Cernosvitov (1939, Bolívia e Perú); Michaelsen (1914, Colômbia); Michaelsen (1912, América Central); Michaelsen (1933. ithas caraibas neerlandezas).

\section{B. Sôbre o gênero Peloscolex}

(Fig. 1-3, 21)

Encontrando em fontes ferruginosas da Pennsylvania, nos arredores de Philadelphia, um verme, em cada segmento provido dum círculo de tubérculos cuticulares, Leidy o descreveu como representante dum novo gênero, 
Peloscolex (1852, p. 124). A espécie típica, $P$ variegatus cujo material original não se acha mais disponivel (Smith 1900, p. 456), dificilmente poderia ser reconhecida com certeza. Desde Vejdovsky (1884, p. 45), - gênero Peloscolex Leidy tem o seu lugar nas Tubificidae, e, assim, representado apenas pela espécie com que foi introduzido na ciência, aparece na monografia de Beddard (1895, p. 258-259). A discussão dêle pondera as relações com a espécie, hoje chamada de Peloscolex ferox (Eisen), inclusive um sinônimo dêste, $\mathrm{Na}$ is $\mathrm{papillosa}$ Kessler, e com as duas espécies de Embolocephalus Randolph (1892, p. 147; 1892a, p. 463, 472), a saber, E velutinus (Grube 1879) e E. plicatus Randolph 1892 .

Todas essas espécies de cuticula espessada $e$, além disso, o verme marinho Tubifex benedii Udekem (1855; corrigido: benedeni). foram por Michaelsen (1900, p. 49-53) reunidas com espécies lisas sob a denominação genérica de $\mathrm{Psammoryctes}$ Vejdovsky. Esse último gênero tinha sido introduzido por Vejdovsky (1876, p. 137) para acentuar particularidades das cerdas e da forma do átrio de Tubifex u mbellifer Lankester (187I, p. 181). Embora seja a espécie de Lankester idêntica a outra (veja Beddard 1895, p. 260), o gênero Ps a m moryctes foi reivindicado por Hrabe (193I p. 21), por enquanto como sub-gênero de Tubifex No apêndice da resenha sistemática de Michaelsen (1900, p. 522, nota 2; p. 524-525) Psammoryctes e, com êste, Peloscolex desaparece na sinonimia de Tubifex Lm.

Quanto ao gênero Ps a m moryctes, já foi mencionada a revalidação por Hrabe (1931). O gênero Peloscolex foi re-introduzido pelo próprio Michaelsen, um ano depois da publicação do "Tierreich" na primeira ocasião em que recebia um $T u b$ ifex papiloso e de cutícula espessada para a determinação. Descreveu-o como Tubifex (Peloscolex) infiatus (Michaelsen 1901, p. 141), justificando, mais tarde (Michaelsen 1903, p. 197 e seg.), o uso do nome Peloscolex, que manteve, como subgênero, tambêm na sua resenha dos Oligoquetos dágua doce (Michaelsen 1909. p. 29). Por fim, $\mathrm{Pel}$ os cole $x$ reaparece como gênero independente na "Fauna do Mar do Norte e do Mar Báltico" (Michaelsen 1927a, p. 18) e, desde então, na literatura em geral, p. e., em Ude (1929, p. 94), Stephenson (1930, p. 745 ) e Hrabe (1931 p. 33).

A diagnose dada por Stephenson (I. c.) diz o seguinte: "Superfície do corpo, do $2 .^{\circ}$ segmento para trás, coberta por papilas cuticulares que tornam opaco o integumento. Ocorrem, além disso, papilas sensoriais, não retrácteis, dispostas em aneis. Feixes dorsais de cerdas compostos por cerdas 
capilares e, geralmente, por agulhas de "crochet" consideravelmente diferentes das agulhas de "crochet" dos feixes ventrais, sendo as últimas unicuspidatas ou bicuspidatas. Duto eferente bem desenvolvido; o átrio contraido no meio, ectalmente dilatado e aí formando câmara distinta. Próstata volumosa, sólida e penis verdadeiro, presentes. Nas espermatecas encontram-se os espermatóforos enroscados em espiral"

Realmente reside na cutícula papilosa ou uniformemente espessada, como no tempo de Leidy, o único critério que permite seguramente reunir as espécies de $\mathrm{Peloscolex}$, visto como não se conhecem os órgãos reprodutivos de todas, nem diferem essencialmente dos de Tubifex.

Em ordem cronológica são as seguintes as espécies atualmente conhecidas de Peloscolex:

1) Peloscolex variegatus Leidy 1852, p. 124. Beddard 1895, p. 258; Michaelsen 1900, p. 53.

2) Preloscolex benedeni (d'Udekem 1855). Beddard 1895, p. 261; Michaelsen 1900. p. 51; 1927a, p. 18; Ude 1929, p. 96; Knöllner 1935, p. 480.

3) Peloscolex velutinus (Grube 1879). Beddard 1895, p. 272; Michaelsen 1900, p. 50; 1909, p. 39; Ude 1929, p. 95.

4) Peloscolex ferox (Eisen 1879). Sinônimo: Embolocephalus plicatus Randolph 1892a, p. 469. Beddard 1895, p. 263, 273; Michaelsen 1900, p. 50, 51; 1909, p. 40; Ude 1929, p. 94.

5) Preloscolex multisetosus (Frank Smith 1900, p. 452). Michaelsen 1900, p. 525.

6) Peloscolex inflatus Michaelsen 1901, p. 141.

7) Peloscolex marinus (Ditlevsen 1904, p. 421).

8) Peloscolex insularis Stephenson 1922, p. 290.

9) Peloscolex stankovici Hrabe 1931, p. 33 (formas: typica sublitoralis e (itoralis)

10) Peloscolex tenuis Hrabe 1931, p. 40.

II) Peloscolex wereschtschagini Michaelsen 1933a, p. 327.

12) Peloscolex pigueti Michaelsen 1933a, p. 327 (Tachydrilus plicatus Piguet 1928, p. 93).

Nessa lista não foi incluida a espécie Peloscolex heterochaetus (Mich.) descrita como Limnodrilus (Michaelsen 1926b, o. 22) e, assim, mencionada várias vezes na literatura (Michaelsen 1927a, p. 17; Ude 1929, p. 83; Stephenson 1930, p. 632, 747; id. 1931, p. 312). Como a cutícula dessa espécie é lisa, não se compreende porque A. de Vos (1936, F. 86), pelo que se pode depreender do "Zoological Record" escreve Peloscolex heterochaetus. Por outro lado, constitue novidade da nossa lista a incorporação de Tubifex marinus Ditlevsen (1904. p. 4I5, 421) no gênero $\mathrm{Peloscolex}$ como espécie independente. A descrição das papilas escuras (p. 422) não deixa dúvida de tratar-se dum 
Peloscolex. A procedência de Tubifex marinus das profundidades do Sund, entre a ilha dinamarqueza Själland e a costa sueca, faria supor ter Ditlevsen tido em mãos Peloscolex benedeni (Udek.). mas, essa espécie encontrou tambêm (1904, p. 421), de maneira que já porisso não se impõe, sem delongas, tal suposição. A descrição de $P$. $m$ a rinus alude, várias vezes, a $E m b o l o c e p h a l u s$ plicatus (Randolph 1892a, p. 46I), espécie idêntica a $P$ ferox Essas alusões significam ser a chetotaxia diferente em $P$ eloscolex benedeni e Tubifex marinus, depreendendo-se isso tambêm da diagnose do último. As cerdas gancheadas bifurcadas de $P$. be nedeni mostram em figuras velhas (Claparède 1863, t. 13 f. 15) e novas (Knöllner 1935, f. 42 p. 481) sempre a ponta superior (ou anterior) menor que a inferior (posterior), ao passo que a espécie nova de Ditlevsen tem o ramo superior um pouco maior (veja Ditlevsen 1904, t. 16 f. II B, i. é, o primeiro " $B$ " constituindo o segundo "B" erro tipográfico, que deveria ser substituido por D). Tubifex ma rinus possue 1-3 cerdas capilares ao lado de 2-3 agulhas gancheadas nos feixes dorsais e $3-5$ cerdas gancheadas nos feixes ventrais; a bainha do penis é nítida e muito comprida. Peloscolex benedeni não tem tubo rígido do penis, e os feixes dorsais, como tambêm os ventrais, são geralmente compostos por duas cerdas gancheadas, raramente por mais, sendo estas unicuspidatas ou indistintamente bicuspidatas. Às vezes, ocorrem, nos feixes dorsais, além das agulhas gancheadas, tambêm cerdas capilares. Cabe, sem dúvida, às autoridades europeias re-examinarem $\mathrm{Tu}$ b ife $x$ marinus e, então, aceitárem essa espécie como independente ou incorporárem-na na sinonimia de $\mathrm{P}$ be nedeni. Como não encontrámos na literatura ao nosso alcance alusão alguma a $T u b i f e x m$ a rinus, que por certo, é um P.eloscolex, tivemos de comparar as diagnoses relativas a êle e a P benedeni. Depois de ter feito isso, não nos sentimos autorizados a reunir P. marinus com qualquer outra espécie do gênero.

\section{Peloscolex evelinae, spec. nov.}

Os vermes teem comprimento de $3 \mathrm{~cm}$., e mais ainda, sendo a espessura (o diâmetro do corpo) de 200-300 $\mu$. As regiões anterior e posterior, frequentemente em grande extensão regeneradas, adquirem o seu diâmetro normal somente certo tempo depois da regeneração completa. $O$ número dos segmentos é muito grande, variando de 150 a 180, exclusive longa zona caudal de acréscimo. Do comprimento, ácima indicado, e do número dos segmentos resulta a brevidade de cada segmento. A côr dos animais é acastanhada e azeitonada, transluzindo o sângue vermelho. O prostômio é incolor, obtuso e provido de cerdas sensoriais. 
As cerdas do corpo começam dorsalmente no $6 .^{\circ}$ segmento, ventralmente no 2..$^{\circ}$ Os feixes dorsais (Fig. 2 A) contem uma única cerda capilar, que á lisa e tem $170 \mu$ de comprimento, $3 \mu$ de espessura. Na base dessa cerda capilar ocorre minúscula cerda acicular, curvada (comprimento: 35-40 $\mu$ ). A terminação da pequena cerda não pode, nem mesmo com imersão, ser reconhecida distintamente; ao que parece, é indivisa e um pouco espessada. Os feixes ventrais (Fig. 2 B,C) são menos fortes nos segmentos 2-5 (comprimento: $108 \mu_{i}$ espessura: $3 \mu$ ) que nos seguintes. Do $6 .^{\circ}$ segmento para trás, onde as cerdas ventrais são relativamente grossas, (comprimento: $120 \mu$; espessura: $5 \mu$ ) elas revelam-se como ôcas. As cerdas ventrais são gancheadas e bifurcadas, com o ramo inferior mais grosso que o superior. São reunidas de 2-4 num feixe, havendo, geralmente, nos feixes posteriores somente 2-3.

Estruturas cuticulares especiais ocorrem do $2 .^{\circ}$ segmento para trás. Apresentam-se como papilas cuticulares em forma de tubérculos escabrosos, até $20 \mu$ de altura e papilas sensoriais, hialinas, 15-30 $\mu$ de altura. Os tubérculos da primeira categoria são desiguais e de côr castanha, em parte mais clara, em parte mais escura. Na região anterior do $2 .^{\circ}-5 .^{\circ}$ segmento, as pequenas verruguinhas acastanhadas, que formam muitos aneis regulares, são menores $e$, entre si, mais uniformes que no corpo restante, onde a sua disposição é menos ordenada. Aí são os tubérculos maiores, de dimensões irregulares e menos numerosos que na região anterior (Fig. 1). $O$ aspeto do animal é hirsuto, porque as papilas cuticulares se prolongam, formando fios ramificados ou compridos pêlos incolores, muito mais longos que as cerdas dorsais capilares e ultrapassando ainda o diâmetro do corpo. Nas regiōes regeneradas são os tubérculos escabrosos menores que nas partes velhas do corpo.

As papilas hialinas, piriformes ou cilíndricas, distalmente providas de curtas cerdas sensoriais, são especialmente numerosas na região anterior; no corpo restante formam, geralmente, um anel segmentar, situado imediatamente antes da cerda dorsal, e outro anel, intersegmentar, equidistante dos aneis precedente e seguinte.

No material dísponivel não se acharam desenvolvidos os órgãos reprodutivos.

Procedência: 1) A espécie foi descoberta pori minha esposa, Exma. Sra. D. EVELINE DU BOIS-REYMOND MARCUS, no tanque cimentado, sito no terrêno da Secção de Ciências Naturais da Faculdade de Filosofia, Ciências e Letras da Universidade des São Paulo. Esse tanque tem de altura dágua $40 \mathrm{~cm}$., vivendo os vermes no fundo, entre as folhas caidas e podres de Ficus elastica. 
2) Mais tarde encontrámos 12 exemplares, já conservados, num tufo de Briozoos Phylactolaemata ( $\mathrm{Stolella}$ agilis forma iheringi veja p. 83 dêsto Boletim) proveniente do Ceará (nordeste do Brasil).

\section{Discussão sôbre a nova espécie}

A separação de Peloscolex evelinae das outras espécies do gênero, acima mencionadas (veja p. 156), não oferece dificuldades. Em $P$ wereschtschagini formam as papilas cuticulares couraça uniforme. Em $P$ pigueti coalescem, na parte papilosa do corpo, i. é, na região entre as cerdas do $4 .^{\circ}$ segmento até o $18^{\circ}$ segmento lo único exemplar conhecido tem 24 segmentos), as papilas em forma de aneis largos. Em $P$ inflatus tal união das papilas ocorre na extremidade posterior do corpo, onde aparecem aneis estreitos em sucessão cerrada. As papilas de $P$ insularis começam no terço caudal do $3 .^{\circ}$ segmento. Nas três formas de $P$ stankovici são as cerdas ventrais, com exceção das externas dos segmentos mais rostrais, unicuspidatas. Cerdas gancheadas flabeliformes na região anterior do dorso caracterizam P. ferox e P. tenuis. O número dos segmentos de P. velutinus varia de 40 a 70 , e os feixes dorsais conteem, além de $1-4$ cerdas capilares, até 4 pequenas cerdas gancheadas. P. multisetosus e P. variegatus possuem 3-14 e 6-10 cerdas capilares, respetivamente. Nos feixes dorsais de $P$ benedeni encontram-se duas, raramente, mais cerdas gancheadas $e$, às vezes, cerdas capilares. em oposição a $P$ evelina e onde a única cerda acicular é extremamente pequena e a cerda capilar sempre presente. $P$. be nedeni é, além disso, espécie marinha ou dágua salobra. A transição ao tipo unicuspidato das cerdas bifurcadas, tão característica de $P$. benedeni, falta em $P$ evelinae Em $P$ marinus são os feixes dorsais formados por 1-3 cerdas capilares e 2-3 gancheadas.

\section{Observações biológicas}

Os vermes lucífugos enovelam-se, quando atingidos pela luz do dia no pequeno vidro de observação ou irritados mecẩnicamente, de tal modo que - animal, de $3 \mathrm{~cm}$. de comprimento, se torna uma bolinha de $3 \mathrm{~mm}$. de diâmetro. No escuro, ou mesmo no claro, quando se teem acostumado ao novo ambiente, desenredam-se pouco a pouco, estendendo-se mais ou menos completamente. Stephenson (1930, p. 64I) cita a "Sistematização das associações no reino animal" de P Deegener ("Die Formen der Vergesellschaftung im Tierreiche" Leipzig 1918), livro êste atualmente não à nossa disposição, mas, cujos traços fundamentais conhecemos, tanto pelas aulas do autor, 
quanto por vários trabalhos zoosociológicos dêle nas nossas mãos. Deegener denomina de "synaporium" sinapório, na ortografia oficial, a associação animal causada por condições desfavoráveis. Tais podem residir no meio externo ou no estado fisiológico, p. e., numa doença. No caso atual tratar-se-ia dum sinapório homotípico, visto se compôr de organismos pertencentes à mesma espécie. No capítulo sôbre a tigmotaxia positiva menciona Herter (1925, p. 5I) o fenômeno como reação agregativa ("Aggregationsreaktion"), citando várias observações a respeito. Dessas parece mais interessante a das aglomerações de Rhynchelmis limosella Hoffm. (Lumbriculidae), unidas durante o dia e dissociadas cada noite, independentemente da iluminação, obedecendo, assim, o sinal da tigmotaxia a um rítmo cronológico. As cerdas sensoriais dos Limnodrili, numerosas e morfologicamente não sem delongas analisáveis, deveriam tornar bastante dificil o trabalho experimental sôbre os tangoreceptores $e_{1}$ mais ainda, sôbre a condução do estímulo. Além da reação agregativa, Peloscolex evelinae não mostra tigmotaxia positiva mais pronunciada do que se. pode esperar dum animal rastejante.

$\mathrm{Na}$ descrição da espécie já aludimos às regenerações frequentemente observadas no nosso material, sujeito a mutilações pela manipulação necessária para isolar os vermes das folhas, sedimentos e algas. Nas zonas regeneradas desenvolvem-se ventralmente em cada segmento, no início, somente duas cerdas bifurcadas, relativamente fracas (Fig. 2 D). No folículo, vizinho à base dessas cerdas pequenas, origina-se a cerda de substituição, de dimensões normais.

O número dos segmentos regenerados, esboçados simultaneamente, pode ser muito grande, num caso, p. e., 100 segmentos, mas, todos, no início da regeneração, de comprimento menor que os velhos. No material atual, tambêm as cabeças foram regeneradas. Os tubérculos escabrosos da região regenerada são menores que os das partes já antes existentes, evidenciando-se, assim, como produtos cuticulares das células da epiderme (hipoderme ou camada matriz, de vários autores).

\section{Notas histológicas}

O integumento de Peloscolex evelina e compõe-se de células epiteliais poligonais (Fig. 3, e), volumosas, mas, chatas, cujos limites são nítidos. A cutícula (t), secretada pela epiderme, cobre a superfície das células tão rente, que forma capa imediatamente aposta ao epitélio. Em consequência da fixação, ou como fenômeno natural, solta-se a cutícula, às vezes, um pouco, notando-se, justamente nêsses casos, o modo da formação das 
papilas. Veem-se então finos fios protoplasmáticos que saem das células epidérmicas e entram na cutícula geral. Os processos protoplasmáticos emanam da célula epitelial, por via de regra, exatamente por cima do núcleo. No ponto em que o fio saido da epiderme toca na superfície externa da cutícula, cresce um tubérculo, cujo centro é constituido por densa aglomeração de secreção. Ao redor da massa central depõe-se substância menos densa, que se tinge do mesmo modo que a cutícula geral. A cutícula do tubérculo ramifica-se na superfície e cobre-se, sôbre as ramificações e entre elas, por grande número de condensações negrejantes. Nessas, trata-se, evidentemente, menos de partículas alheias, mas, na espécie atual, principalmente, de enduramentos irregulares da própria cutícula. Entre os vários tubérculos é a cutícula lisa, podendo, em cutículas velhas, dois ou três tubérculos concrescerem, como se reconhece pelo número dos centros de secreção densos e pelas dimensões de tais gibas. Em zonas jovens, regeneradas, são as células epidérmicas caracterizadas pela sua pequenez e o número, consequentemente, maior. A cutícula recem-formada começa plana, crescendo depois os tubérculos sucessivamente (Fig. 3 B).

As papilas sensoriais ( $n$ ) são igualmente cobertas pela cutícula, embora muito mais tênue, que forma, na cúpola da papila, uma orla de bastonetes, e, além disso, 1-3 pêlos sensoriais, provavelmente tácteis. As células sensoriais, pertencentes a uma papila, formam pequeno grupo ou botão intraepitelial, colocando-se, frequentemente, um núcleo dessas células por cima dos outros. Limites entre as células sensoriais não se veem, como tambêm não se destacam em preparações coradas pelos métodos usuais as fibras nervosas basais, por certo, muito finas. Por outro lado, nota-se diferenciação fibrosa no protoplasma da papila, e isso, com grande regularidade, tanto nos cortes longitudinais, quanto nos transversais, cujo centro pontilhado revela a presença de elementos especiais. Nêles trata-se, evidentemente, das neurofibrilas, que transmitem a irritação recebida pelas terminações cuticulares às células sensoriais.

A literatura a respeito das papilas dermáticas nas espécies do gênero Peloscolex foi reunida por Stephenson (1930, p. 25, 312), havendo, além disso, vários cortes da pele no trabalho de Hrabe (1931). Além do fato de ocorrerem sempre dois tipos de papilas, as cuticulares ("Sekretpapillen" de Hrabe), e as sensoriais, revestidas por fina camada cuticular, não ha muitos pontos em que concordam os achados anteriormente publicados com os aquí apresentados. Evidentemente varia muito, de uma espécie para outra, - tamanho das papilas cuticulares, como tambêm a incorporação de partículas alheias na secreção da epiderme. Foi, ao que parece, o centro de 
secreção das papilas cuticulares que levou Delphy (1921, citado segundo Stephenson 1922, p. 289; 1930, p. 26) à opinião de se tratar nelas de células eliminadas do conjunto epitelial. As papilas das zonas regeneradas são bastante uniformes em $P$. evelina $e_{1} e_{1}$ assim, distinguem-se durante muito tempo das papilas do corpo restante que apresentam, na espécie atual, certa variação das dimensões dentro da mesma região. Tal achado parece indicar que as papilas velhas se desintegram e são substituidas por papilas novamente secretadas. Stephenson pensa na possibilidade de função excretora das papilas. Simultânea ou exclusivamente, poderiam tambêm funcionar no sentido de proporcionar ao verme contato mais íntimo com a vasa, em que vive, ou simplesmente proteger a epiderme, podendo a separação das papilas velhas ser causada mecanicamente. Somente experiências com vermes vivos, mantidos em meios diferentes, poderiam esclarecer a função das papilas cuticulares das espécies de $\mathrm{Pelos}$ colex.

As referências a respeito das papilas sensoriais são muito escassas (Stephenson 1930, p. 312). Hrabe (1931 p. 36) diz: "as células sensoriais são providas de bastonetes sensoriais" (figura $6 \mathrm{k}$ no texto, papila esquerda), mas, a ilustração indicada mostra apenas o plasma no ápice da papila indistintamente estriado, e na base aproximadamente da papila, três núcleos, eventualmente combináveis com a papila. A ausência de musculatura circular e dos limites entre as células da epiderme nessa figura e nas outras (1. c., f. $6 i, 7 \mathrm{~g})$ fazem crêr ter Hrabe, aliás grande autoridade na sistemática dos Oligochaeta, disposto apenas de material fixado para fins taxonômicos, realmente os únicos visados no trabalho citado.

Em várias Naididae conhecem-se papilas sensoriais, por princípio, semethantes às ocorrentes em Peloscolex evelinae. Reproduziu, p. e., Stephenson (1930, f. 132) uma figura, dada por Vejdovsky, do órgão sensorial epitelial de Slavina appendiculata (Udek.), e Brode (1898, t. 14, f. 16) desenhou o órgão sensorial de Aulophorus vagus Leidy. justamente nas duas espécies mencionadas, cujos órgãos sensoriais cutâneos despertaram a nossa atenção, quando folheámos a literatura, trata-se de vermes, cuja pele se acha coberta por capa de partículas alheias. Em correlação com isso são os órgãos sensoriais dermáticos especialmente desenvolvidos, dispostos em aneis ao redor do corpo, e em Slavina appendiculata, além disso, elevados em papilas. Impõe-se, sem delongas, a comparação com Peloscolex evelinae, cujas papilas cuticulares, senão fossem acompanhadas por papilas sensoriais, diminuiriam a possibilidade do verme em se orientar sôbre as qualidades do seu ambiente. 


\section{Sôbre o gênero Limnodrilus}

(Fig. 4-20, 22)

Dentro dos gêneros das Tubificidae com órgão copulador (penis) verdadeiro e com glândula acompanhadora sólida (próstata) do átrio, i. é, a dilatação do duto eferente, o gênero Limnodrilus Claparède 1862 caracteriza-se pela igualdade dos feixes dorsais e ventrais de cerdas bifurcadas. Um caso excepcional, mencionado por Michaelsen (1928, p. 88), passamos deliberadamente em claro. A bainha chitínica, rígida, do órgão copulador, que figura ainda nas diagnoses genéricas de Beddard (1895, p. 248) e Michaelsen (1900, p. 42-43), não se apresenta invariavelmente em todas as espécies (Stephenson 1931, p. 312). Visto que o gênero, espalhado no mundo inteiro, abrange 44 espécies, nem todas válidas, é verdade, a presença ou ausência da bainha chitínica parece possibilitar divisão ulterior dessa entidade sistemática complexa. Mas, em certas espécies pertencentes ao grupo das desprovidas de bainha penial propriamente dita, ocorre o revestimento do penis por cutícula algo espessada, às vezes, extensiva à câmara de alojamento do órgão. Tal estrutura intermediária entre a da bainha típica e a outra, do órgão copulador mole, recomenda manter o gênero indiviso.

O número das espécies mais que triplicou desde a última resenha sistemática dos Oligoquetos (Michaelsen 1900, p. 42-46). A necessidade de classificar o material colhido em São Paulo obrigava-nos a reunir quanto possivel do inventário do gênero. O resumo do estado atual da taxonomia de Limnodrilus pode ser util para orientar os que futuramente encontrarem espécies do gênero no país, embora não seja possivel determiná-las com as indicações, aquí publicadas, que informam apenas de maneira muito sumária. As diagnoses curtas, como ainda figuram na dita sinopse do sistema dos Oligochaeta, cairam, no gênero em questão, em desuso. Pensamos que talvez o caminho entre os extremos, a saber, a enumeração dos nomes e a cópia das descrições extensas, fosse o mais próprio para a primeira orientação.
A. Espécies providas de bainha do penis chitínica e rígida.

1. ${ }^{\circ}$ Grupo. Bainha curta, 2-6 vezes tão comprida quão larga ou menos longa ainda.

I. L. alpestris Eisen 1879 (Michaelsen 1900, p. 44). Bainha 1:6. Comprimento dos vermes: $25 \mathrm{~mm}$., diâmetro: $750 \mu$, portanto, pequenos e relativamente grossos.

2. L. gracilis Moore (1906, p. 169-170). Comprimento: 75 mm.; 140-175 segmentos. As espermatecas dirigem-se, do orifício sito na linha das cerdas ventrais, ver- 
ticalmente para cima, até quasi atingirem a parede dorsal do corpo. Duto e ampôla das espermatecas não claramente distintos. Bainha I:5-6.

3. L. grandisetosus Nomura (1932, p. 511). Bainha muito curta, 1:2. Cerdas ventrais dos segmentos IV-X muito grossas. Os vermes são, provavelmente, proterogínicos.

4. L. helveticus Piguet 1913 (Ude 1929, p. 84). Bainha I:5i comprimento 25-40 mm.i número dos segmentos 50-65; duto das espermatecas entalmente estreito, ectalmente dilatado.

5. L. neotropicus Cernosvitov (1939, p. 106). A bainha $(1: 4-5,5)$ termina com dilatação globosa.

6. L. ornatus Eisen 1879 (Michaelsen 1900, p. 43). A bainha (1:5) possue coroa de corpúsculos chitínicos na circunferência ental.

7. L. silvani Eisen 1879 (Michaelsen 1900, p. 44-45). A bainha $(1: 3-4)$ é lateralmente achatada.

8. L. steigerwaldi Eisen 1879 (Michaelsen 1900, p. 46). Comprimento: ca. de 80 mm.; diâmetro: 0,75-1 mm. Apesar das indicações a respeito da bainha com $1: 5$ (Beddard 1895, p. 253) e I:6 (Michaelsen, I. c.), pensa Cernosvitov (1939) p. 105) na probabilidade de ser a espécie idêntica a $L$. hoffmeisteri. Friend $(1912$, p. 271$)$ indica a proporção da bainha com 1:8 e considera a espécie como variedade de L. hoffmeisteri

9. L. udekemianus Claparède 1862 (Ude 1929, p. 82). O genótipo. Tiem de comprimento $30-40 \mathrm{~mm}$., ca. de 160 segmentos e a bainha $1: 4$. Friend (1912, p. 272) descreveu a var. wordsworthianus com o prostomio, e ।.: segmento papilosos e com duto da espermateca muito comprido.

10. L. willeyi Nomura (1913, p. 1,34), semelhante a L. udekemianus, mas, com número dos segmentos igual, a saber, 100-180, tem $80-100 \mathrm{~mm}$. de comprimento. Bainha 1:3-4.

II. L. spec. (Stephenson 1929, p. 227). Até $\circ 8 .^{\circ}$ ou 11.9 segmento ocorrem 2-3 cerdas ventrais; daí para trás somente I. $\bigcirc$ verme é muito delgado, tendo na região anterior, que é a mais grossa, diâmetro de $500 \mu$, sendo o comprimento de $120 \mathrm{~mm}$. Bainha $1: 2$. Distingue-se de L. grandisetosus pela falta das cerdas grossas e poderia ser denominada, pois difere de todas as espécies restantes do gênero.

11. Grupo. Bainha de comprimento médio, pelo menos 8, geralmente 9-13 vezes tão longa quão larga.

12. L. aurantiacus Friend $\left(1911\right.$, p. $414 ; 1912$, p. 274). Células intestinais do $8 .^{\circ}$ segmento para trás alaranjadas em vários ("several") segmentos. Bainha $1: 13$.

13. L. aurostriatus Southern (1909, p. 136). Nos segmentos anteriores de viva côr vermelha; para trás mais pálido. Cada segmento com dois aneis aúreos. Espermatecas com ampôla espaçosa e duto largo, ligados por passagem estreita. Átrio comprido e delgado; bainha $1: 8-9$.

14. L. corallinus (Eisen 1879) (Michaelsen 1900, p. 46). Vermes relativamente grossos; diâmetro de 1-1,5 mm.i comprimento de 25-70 mm. Bainha 1:8 (Beddard 1895, p. 254); $1: 9$ (Michaelsen, 1. c.). Segundo Cernosvitov (1939, p. 105). provavelmente um sinônimo de $L$. hoffmeisteri. 
15. L. dugèsi Rybka 1898 (Michaelsen 1900, p. 45). Bainha fortemente curva, I: 12. Comprimento do corpo de 40-70 mm.; diâmetro de ca. de $1 \mathrm{~mm}$.

16. L. galeritus Friend (19/2, p. 278). Orifícios das espermatecas cobertos por saliências mamilares. Bainha $1: 15$.

17. L. gotoi Hatai $(1899$, p. 5$)$. Comprimento de $70 \mathrm{~mm}$. diâmetro de $2 \mathrm{~mm}$.; $100-150$ segmentos. Bainha $1: 4$ (na f. 8), 1:9-11 (nas f. 1,3, 10). Por causa dessa desharmonia pensou Nomura (1913) ter Hatai trabalhado com material heterogêneo e chamou espécimes de Tókio, com bainha de $1: 3-4$, de L. willeyi, outros, de procedência igual, mas, com bainha de $1: 10-11$, de L. goto $i$ Hatai. Cernosvitov (1939, p. 105) inclue L. gotoi Hatai na sinonimia de L. hoffmeisteri. Seja notado que o saco espermático anterior duplo e a falta de espermatóforos, caracteres de L. gotoi Nomura, não foram veerificados em L. gotoi Hatai.

18. L. gotoi Nomura (1913, p. 3). Além da identidade incerta dessa espécie a L. go o Hatai, é ela, seguramente, um sinônimo de L. socialis Stephenson 1912 (Nomura 1913, p. 46; id. 1929, p. 131; Stephenson 1923, p. 98).

19. L. hoffmeisteri Claparède 1862 (Ude 1929, p. 82). Material europeu típico tem de comprimento 20-50 mm., 55-95 segmentos, e bainha de $1: 11-12$. Friend (1912, p. 27I) descreveu a var. tenellus com a bainha de $1: 4-6$, evidentemente não pertencente a $L$. hoffmeisteri, mas, descrita tão sumariamente que não pode ser julgada.

20. L. igneus (Eisen 1879) (Michaelsen 1900, p. 45). Quando vivente, tem côr de fogo: comprimento de $30 \mathrm{~mm}$. i diâmetro de $750 \mu$. A bainha reta, tem proporção de $1: 12$.

21 L. lucasi Benham (1903, p. 216). Segundo o autor, semelhante a L. dug èsi. A bifurcação das cerdas com ramos de comprimento igual, sendo o proximal mais grosso que o distal. Comprimento do corpo de $15-35 \mathrm{~mm}$.; diâmetro de 250 $500 \mu_{i}$ número dos segmentos, 60-80. Não ha vasos cutâneos. Bainha ca. de $1: 10$.

22. L. monticola Eisen 1879 (Michaelsen 1900, p. 46). Comprimento e diâmetro como em L. igneus. Ramo distal das cerdas algo mais comprido que o proximal. Bainha ca. de I:8, muito fracamente encurvada. Segundo Cernosvitov (1939. p. 105), provavelmente idêntico a $L$. hoff $m$ eisteri.

23. L. parvus Southern (1909, p. 137-138) com a var. biannulatus Lastochkin (1927, p. 18). Bainha de 1:9-13. E' menor que L. hoffmeisteri e, nas cerdas anteriores, é o ramo proximal maior que o distal. Por Cernosvitov (1939, p. 104-105) incorporado na sinonimia de L. hoffmeisteri foi aquí considerado (veja p. 167) como forma do mesmo.

24. L. socialis Stephenson $(1912 ; 1917$, p. 93; 1923, p. 96). Comprimento de 70-100 mm.; diâmetro menor que I mm.i bainha I: 10-1I. Por Michaelsen (1935, p. 100-102) e Cernosvitov (1939, p. 105) incluido na sinonimia de L. h off. meisteri (veja p. 173).

25. L. subsalsus Moore (1905, p. 392). Comprimento de $40 \mathrm{~mm}$., no máximo; diâmetro máximo, $600 \mu_{i} 120$ segmentos. Bainha I:12-13. Ciernosvitov (1939, p. 105) considera a espécie idêntica a $L$. hoffmeisteri

26. L. vejdovskyanus Benham (1903, p. 213). Comprimento de 20-25 mm.; diâmetro de $750 \mu$ até I mm., portanto, relativamentie grosso. Segmentos, 66-75, mais 33-40 muito curtos, regenerados. Bainha ca. de $1: 10$. 
III. Grupo. Bainha comprida, 20 e mais vezes tão longa quão larga.

27. L. claparèdeanus Ratzel, (1868, p. 590). Comprimento $40-80$ mm.; 78-160 segmentos; bainha 1:23-31. Sinônimos, segundo Michaelsen (1900, p. 45): L. cali fornicus (Eisen 1879), L. spiralis (Eisen 1879); segundo Ude (1929, p. 82): L. I ongus -Bnetscher 1901. Southern (1909, p. 136) e Friend (1912, p. 273-274) manteem a última espécie separadamente.

28. L. motomurai Nomura (1929, p. 131, 137). Comprimento de $50-80$ mm.; 100-150 segmentos; proporção da bainha $1: 30-33$.

B. Espécies sem tubo chitínico, rígido, ao redor do penis inteiro.

29. L. arenarius Michaelsen (1926c, p. 155) e var. in a equalis Michaelsen \& Verescagin 1930. A cutícula que reveste o penis é tênuei a da câmara, um pouco mais espessada. Cerdas genitais, I por feixe, no $10^{\circ}$ segmento. O nome da variedade deveria ser modificado, pois já ocorre, como nome específico no gênero (veja n.ं40).

30. L. baicalensis Michaelsen (1901, p. 140). Penis sem revestimento chitínico; cerdas genitais, unicuspidatas, I por feixe, no $10^{\circ}$ segmento.

31. L. chacoensis Stephenson (1931, p. 309). O penis, que é curto e dobrado quando retraido, e a câmara são cobertos por cutícula contínua com a da superfície do corpo e de tenuidade igual.

32. L. dybowskii (Grube 1873) (Michaelsen 1900, p. 65). Geralmente, não mais de 2 cerdas por feixe. $O$ penis e a câmara revestidos por cutícula muito grossa.

33. L. heterochaetus Michaelsen (1926b, p. 22). As cerdas das regiōes média e postorior do corpo são unicuspidatas.

34. L. michaelseni Lastochkin (1937, p. 233). As cerdas ventrais dos segmentos IX-XII (uma por feixe) são maiores $(125-145 \mu)$ que as outras $(72-118 \mu)$ e possuem ramo distal comprido e afiado (reduzido rias cerdas restantes), sendo o ramo proximal disposto perpendicularmente sôbre o eixo da cerda.

35. L. newaensis Michaelsen (1903a, p. 3; 1923, p. 42). Corpo, até 10. segmento, amplamente provido de vasos serpenteantes. As linhas laterais, verificáveis à luz direta, conteem os póros das espermatecas. Somente o saco espermático anterior existe. A cutícula do penis espessada forma um anel, tão longo quão largo, especialmente grosso e comparavel à bainha das espécies da secção A.

36. L. papillosus Friend (1912, p. 276). Coberto de pequenas papilas. Espermatecas estriadas, sem duto distinto. No lugar da bainha, um saco, munido, no centro, de processo chitínico, segundo a figura, uma cerda penial.

37. L. trisetosus Friend (1912, p. 277). Nos segmentos anteriores e posteriores uniformemente 3 cerdas por feixe. Espermateca sem duto. Duto eferente dilatado em forma de saco.

38. L. virulentus (Pointner 1911, p. 637). O penis tão curto e a cutícula dêle e da câmara tão fina quão em L. chacoensis. O átrio é tubiforme, quasi não dilatado em comparação com o duto masculino. A próstata é exígua.

C. Espécies cujo órgão copulador e, com isso, a bainha, se ignora.

39. L. (2) aequatorialis Michaelsen (1935a, p. 34). A espécie possue, do $3 .^{\circ}$ segmento para tras, poros dorsais. 
40. L. inaequalis friend $(19 \mid 2$, p. 277$\}$. Sem bainha penial. Ramo distal da bifurcação da cerda muito curto, seguido por 2-3 pontas proximais.

41. L. nervosus Friend (19/2, p. 279). Os gânglios ventrais dos segmentos 1-5 são dilatados para os dois lados; a comissura faringea é muito forte.

D. Espécies, cujas diagnoses ainda não foram vistas por nós.

42. L. crassus L. Andrusoff (19/4, Kiev Zapiski obsc. jest. v. 32 n. 4, p. 92 f. 1-3). A posição genérica é duvidosa, segundo o próprio autor.

43. L. pacificus Chen (1935, Abstr. Papers Scient. Conference Nanking, p. 49).

44. L. phreodriloides Michaelsen. Possue, segundo Michaelsen (1928, p. 88), cerdas do tipo da família Phreodrilidae, i.é, cerdas dorsais unicuspidatas, pêlos ou agulhas $e_{1}$ nos feixes ventrais, dois ganchos, uni ou bi-cuspidatos.

\section{Descrições sistemáticas}

\section{Limnodrilus hoffmeisteri forma parva Southern}

(Fig. 4-5)

Limnodrilus parvus Southern 1909, p. 137 t. 8 f. 5.

Limnodrilus hoffmeisteri Cernosvitov 1939, p. 104-106 f. 76-85.

Os vermes viventes teem $20-30 \mathrm{~mm}$. de comprimento e ca. de $500 \mu$ de diâmetro. O número dos segmentos importa, aproximadamente, em 120. Os segmentos são, em vermes viventes, um pouco mais compridos que largos. A espessura do revestimento do corpo, i. é, cutícula, epiderme, tubo músculo-dermático e somatopleura em conjunto, é de $11-16 \mu$ nos cortes. A côr é vermelha, tirando à carmim.

O prostômio, examinado em vermes conservados, e assim, algo contraidos, é obtuso e um pouco mais largo que comprido. Os segmentos II-VI são bi-anulados, sendo o anel anterior mais estreito que o posterior.

Nos segmentos anteriores ocorrem 3-6 cerdas bifurcadas por feixe, de comprimento de $64 \mu_{i}$ atrás do clitelo há primeiramente 4 , mais para trás, 2 ou 3; nos últimos segmentos, existem apenas 2 . As cerdas da metade posterior não ultrapassam $45 \mu$ de comprimento. Em todas as cerdas do material aquí em mãos é o ramo proximal da bifurcação mais grosso que o distal (Fig. 4): nas cerdas anteriores, quer dizer, até os segmentos VI-IX, 。 ramo proximaí é tambêm mais longo que o distal (Fig. 4 A). As cerdas são sólidas e incolores. Nas cerdas do $200^{\circ}$ segmento, aproximadamente, para trás (Fig. 4-B) é a parte ectal, i. é, a situada distalmente ao nódulo, sempre muito mais fina que a ental, e por isso, dobra-se frequentemente. Indivíduos sexualmente maduros carecem de cerdas ventrais no $11 .^{\circ}$ segmento. 
A faringe atinge o septo $3 / 4 ;$ o esôfago ocupa $\circ 4 .^{\circ}$ segmento. As células cloragógenas começam atrás do dissepimento 4/5. Existe somente um único par de corações (Fig. $5, c$ ), sito no $8 .^{\circ}$ segmento. $O$ vaso dorsal (Fig. 5, g) faz no 9. segmento uma curva para o lado direito, antes de descer no lado esquerdo. Os vasos cutâneos, desenvolvidos na metade posterior do verme são do mesmo tipo dos descritos da forma seguinte (p. 180), sendo apenas as duas alças principais de cada, segmento (Fig. 14) um pouco menos onduladas. São igualmente as comissuras anteriores, as chamadas comissuras celomáticas, presentes nos segmentos IV-VII, menos tortuosas que naquela forma (Fig. 11,0 ). Nos segmentos VII e VIII são os nefrídios (Fig. 5, n) revestidos por células vesiculosas.

O clitelo (Fig. 5, i), pouco saliente, ocupa os segmentos XI e XII. Os testículos são, no material à nossa disposição, proeminências curtas $(t)$ do dissepimento 9/10. Os ovários (o), em forma de $S$, são volumosos e situados no $11 .^{\circ}$ segmento; empurram o septo $11 / 12$ de tal modo para trás que êste não se mantem nítido no auge da maturidade dos órgãos reprodutivos. A zona do crescimento dos ovócitos acha-se localizada no bordo interno do ovário. Os ovidutos teem a mesma posição como na forma seguinte (Fig. 8, f). O ovisaco extende-se da sua origem no dissepimento $11 / 12$ até - 17. segmento ou mais para trás ainda, conforme o gráu de enchimento pelos ovócitos. Os gonócitos masculinos são armazenados em três sacos espermáticos (Fig. 5, e), dois anteriores, sitos no 9. segmento, e um posterior, inserido no dissepimento $10 / 11$ e extendido até o $14 .^{\circ}$ segmento. Os funís masculinos veem-se no $10^{\circ}$ segmento (Fig. 5, f); o duto masculino (d) é, no trecho anterior ao átrio, enroscado e tem $20 \mu$ de diâmetro. $O$ átrio (a) é grande, com $200-276 \mu$ de longo e $62 \mu$ de largo. A próstata (p) tem de comprimento $180 \mu$ e de largura $100 \mu$ i é externamente lisa, não lobulada, e comunica-se com o átrio por duto pedunculiforme. $O$ átrio e a glândula acompanhadora pertencem ao $12 .^{\circ}$ segmento e foram apenas pela compressão da lâmina, em que se baseia a Fig. 5, deslocados, para o segmento seguinte. O duto masculino atrás do átrio é curto e possue de diâmetro $27 \mu$. O órgão copulador inclusive a sua bainha chitínica (Fig. 5, b) corresponde com $\circ$ infundíbulo terminal e o corte transversal orbicular ao penis de $L$. hoffmeisteri, mas, é muito pequeno, pois possue de comprimento 230-300 $\mu$ e de largura 23-27 $\mu_{1}$ na extremidade interna (ental). Resulta disso que a proporção entre a largura ental e o comprimento é de 1:10 a 1:11. A parede do penis é relativamente grossa $(2-3 \mu)$ : a musculatura circumda a bainha em espiral, cruzando-se as fibras de dois músculos, dos quais um se insere entalmente, o outro, antes da dilatação ectal. 
Procedência: I) Tanque no terrêno da Secção de Ciências Naturais da Faculdade de Filosofia, Ciências e Letras da Universidade de São Paulo. 2) Córrego num bairro periférico ("Jardim Europa") da cidade de São Paulo. 3) Em águas pertencentes ao Tieté, cidade de São Paulo (bairro da Lapa).

Entre a separação específica de Limnodrilus parvus, baseada, principalmente, na predominância do ramo proximal da bifurcação das cerdas anteriores sôbre o distal, e a incorporação completa da espécie em $L$ hoffmeisteri, proposta por Cennosvitov (l. c.), recomendamos a manutenção do nome original, aplicando-o a uma forma de L. hoffmeisteri Como foi exposto por Cernosvitov, a longura maior do ramo inferior pode restringir-se às cerdas dos feixes mais anteriores, ou mesmo, às cerdas do 2.' segmento, quer dizer, ao primeiro provido de cerdas. Segundo Cernosvitov, ha até espécimes em que a "diferença apenas pode ser verificada" Mas, como o autor escreve: "os exemplares com os caracteres de Limnodrilus parvus são usualmente menores que os representantes indubitáveis de L. hoffmeisteri" acentua-se mais nitidamente o quadro de L. parvus. O material atual, embora proveniente de localidades diferentes, é bastante uniforme quanto ao caracter das cerdas acima mencionado. Além disso, são os limites inferiores das medidas da bainha do penis dos espécimes presentes, a saber, $230 \mu$ de comprimento e $23 \mu$ de diâmetro ental, menores que os limites inferiores da tabela de Cernosvitov (1939, p. 105), i. é, $300 \mu$, e $25 \mu$, respetivamente. Os máximos das medidas aqui verificadas, $300 \mu$ e $27 \mu$, avizinham-se a êsses mínimos. Cernosvitov indica a procedência do material que ostenta caracteres de $\downarrow$. parvus separadamente e não diz que haja transições sucessivas entre tais populações e outras de $L$ hoffmeisteri forma typica Trata-se, portanto, de diferenças, sem dúvida, pequenas, mas verificáveis, como se objetivam ao nosso vêr, da melhor maneira pela introdução da "forma parva Southern 1909" de L hoffmeisteri

Distribuição geográfica: A forma parva foi assinalada do Lago de Titicaca, da Inglaterra e Irlanda, do Congo Belga e das Índias Orientais.

Limnodrilus hoffmeisteri Claparède forma divergens, $\mathrm{f}$. nov. (Fig. 6-9)

O comprimento de animais viventes é de $50-70 \mathrm{~mm}$., ao passo que conservados não ultrapassam $40 \mathrm{~mm}$. O diâmetro, em geral, é de $600 \mu_{1}$ 
alcançando no clitelo $800 \mu_{i}$ os animais fixados e contraidos teem de diâ. metro 800-1000 $\mu$. A espessura da parede do corpo, i. é, epiderme + musculatura e somatopleura, medida fora da região do clitelo, é de 25-46 $\underline{\mu}$ nos cortes. O corpo turgescente locomove-se vivamente, tendendo, quando manipulado, a enroscar-se em espirat. O número dos segmentos importa em 90-170 e mais ainda, tendo sido contados até 210 segmentos. A côr dos vermes é vermelha pelo transluzimento do sângue. Intersegmentarmente ocorrem, nomeadamente nos segmentos posteriores, faixas alaranjadas. Tambem os nefrídios dos segmentos posteriores são, parcialmente, de côr alaranjada viva.

O prostômio de vermes conservados é pouco mais curto que largo; em vermes viventes é tão comprido quão largo ou, segundo a contração, mais curto ou mais longo. Os segmentos II-VI são bi-anulados, sendo o anel anterior mais estreito que $\circ$ posterior. Nos segmentos post-clitelares formam células glandulares cutâneas uma cintura, sita ao nivel das cerdas. 0 comprimento dos segmentos, quer dizer, a distância antero-posterior, é um pouco menor que o diâmetro dos vermes.

Os feixes das cerdas bifurcadas encontram-se, nos segmentos II-VI, no meio do segmento; na região seguinte, ainda ante-clitelar, no terço posterior do segmento; na zona post-clitelar, no quinto posterior. As cerdas, ligeiramente curvas e bifurcadas, são ôcas e providas de nódulo situado externamente (ectalmente) ao centro da cerda; na cavidade da cerda apresenta-se, várias vezes, conteúdo preto. O número das cerdas dos segmentos anteriores é de 7-11 por feixe, havendo mais 1-2 cerdas de substituição. Para trás diminue o número das cerdas sucessivamente, de maneira que os últimos segmentos possuem apenas 2 cerdas. O comprimento das cerdas anteriores é de 160 . $\mu$. declinando daí a longura, até importar em $105 \mu$ nas cerdas posteriores. Em animais sexualmente maduros faltam cerdas ventrais no $11^{\circ}$ segmento, cujas cerdas dorsais são regularmente desenvolvidas. Nas cerdas dos segmentos anteriores (Fig. 6B) é o ramo distal da bifurcação mais comprido e fino que o proximal; na região caudat apresenta-se o ramo proximal como mais robusto (Fig. $6 \mathrm{~A}$ ): na parte média do corpo forma-se uma zona de transição, sendo aí iguais os dois ramos. Nas cerdas dorsais dos segmentos II-V houve num terço, aproximadamente, do material estudado uma ponta accessória (Fig. 6 C). 
Chetotaxia dos segmentos II-X de Limnodrilus hoffmeisteri f. divergens.

\begin{tabular}{|c|c|c|c|c|}
\hline Segmento & $\begin{array}{c}\text { número das cer- } \\
\text { das dorsais }\end{array}$ & $\begin{array}{c}\text { comprimento das } \\
\text { cerdas dorsais } \\
\text { (em micra) }\end{array}$ & $\begin{array}{c}\text { número das cer- } \\
\text { das ventrais }\end{array}$ & $\begin{array}{c}\text { comprimento das } \\
\text { cerdas ventrais } \\
\text { (em micra) }\end{array}$ \\
\hline III & 7 & 109 & 7 & 105 \\
IV & 9 & 125 & 9 & 118 \\
V & 11 & 152 & 10 & 135 \\
VI & 6 & 145 & 10 & 145 \\
VII & 8 & 150 & 9 & 150 \\
VIII & 8 & 160 & 8 & 160 \\
IX & 8 & 155 & 8 & 158 \\
X & 7 & 153 & 8 & 150 \\
\hline
\end{tabular}

O cérebro (gânglio suprafaringeo) (Fig. 7) ostenta nostralmente concavidade oval e, caudalmente, outra, menos profunda. A faringe extende-se, para trás, até o fim do $3 .^{\circ}$ segmento. Células cromófilas parecem ausentes. O esôfago é curto e ocupa somente o $4 .^{\circ}$ segmento, ocorrendo células cloragógenas (cloragócitos) do $5 .^{\circ}$ segmento para trás. Os dissepimentos $3 / 4 \mathrm{e}$ seguintes, até o 9/10, são algo espessados. Vasos cutâneos são desenvolvidos na metade posterior. Corações existem apenas no $8 .^{\circ}$ segmento, portanto, um único par. Nefrídios com células vesiculosas mostram-se no $7 .^{\circ}$ e no $8 .^{\circ} \mathrm{seg}$ mento.

O clitelo abrange os segmentos 11 e 12, salientando-se nos vermes viventes por ser grosso e esbranquiçado. Os testículos (Fig. 8, t), muito grandes, são situados no $10^{\circ}$ segmento. Os ovários (Fig. 8, 이 são enormes e podem, do seu segmento original, o $11 .^{\circ}$, extender-se ao 12 . O oviduto (f). sito posteriormente no $11 .^{\circ}$ segmento, desemboca externamente com orifício transversal, fendiforme, dificilmente perceptivel. $O$ ovisaco (i) sai do dissepimento $11 / 12$ e atinge o 19. segmento. Os sacos espermáticos (e) anteriores são pares e originam-se do septo 9/10; o posterior, impar, do dissepimento 10/11. Os sacos anteriores encontram-se no 9. segmento; o posterior extende-se até o 17. segmento. Os funís masculinos (m) começam ventralmente no $10^{\circ}$ segmento; são muito grandes e lobados. O duto masculino (d) pre-atrial (o "vas deferens" da litenatura) é estreito (36 $\mu$ de diâmetro), ciliado e enroscado. O átrio (a) tem $210-460 \mu$ de comprimento e 60-100 $\mu$ de diâmetro. A próstata (p), fracamente lobada no bordo externo, tem ca. de $160 \mu$ de comprimento e ca. de $80 \mu$ de largura. O duto masculino post-atrial (o "ductus efferens" da literatura) tem de diâmetro $40-45 \mu$ e ca. de $400 \mu$ de comprimento. O penis, cuja cứricula não é especialmente espessada, acha-se circumdado por bainha chitínica (b). incolor e tênue. A bainha do penis (Fig. 9) apresenta-se como cir- 
cular no corte transversal, estreita-se da extremidade interna (ental) paro fora, mas. dilata-se na terminação externa (ectal) infundibuliformemente. Tanto na extremidade ental, quanto pouco antes da ectal, insere-se um músculo na bainha do penis. As fibras dêsses músculos envolvem a bainha em disposição espirai, cruzando-se.

Medidas do comprimento e do diâmetro (medido na extremidade interna ou ental), em micra, da bainha do penis de Limnodrilus hoffmeisteri forma divergens.

\begin{tabular}{|c|c|c|c|}
\hline $\begin{array}{c}\text { Número do } \\
\text { exemplar }\end{array}$ & Comprimento & $\begin{array}{c}\text { Diâmetro, entalmente } \\
\text { medido }\end{array}$ & Proporção \\
\hline 1 & 512 & 64 & $1: 8$ \\
2 & 490 & 46 & $1: 10,6$ \\
3 & 545 & 60 & $1: 9$ \\
4 & 460 & 64 & $1: 7,2$ \\
5 & 470 & 65 & $1: 7,2$ \\
6 & 485 & 70 & $1: 6,9$ \\
7 & 460 & 58 & $1: 7,9$ \\
8 & 530 & 73 & $1: 9,6$ \\
9 & 545 & 57 & $1: 8,4$ \\
10 & 545 & 65 & $1: 8,3$ \\
\hline
\end{tabular}

Para dar uma ideia do estreitamento da bainha do penis em direção ectal, seja mencionado que as bainhas dos exemplares 2 e 3 da tabela acima ostentam 28 e 27 micra, respectivamente, como medidas do ponto mais estreito, sem que exista relação entre o diâmetro na extremidade ental e o estreitamento máximo, como se vê pelos exemplos escolhidos. Os orifícios das espermatecas (Fig. 8, s) aparecem como fendas transversais, situadas antes das cerdas do $10^{\circ}$ segmento. Espermatóforos foram raramente encontrados nos cortes.

Procedência: Tanque no terrêno da Seç̧ão de Ciências Naturais da Faculdade de Filosofia, Ciências e Letras da Universidade de São Paulo.

\section{Discussão}

A forma presente concorda em vários caracteres, não, porém, em todos, com Limnodrilus socialis Stephenson 1912, conhecido das Indias, do Ceylão, de Java (Michaelsen \& Boldt 1932, p. 598) e do Japão. A iden- 
tidade de L. goto $i$ Nomura 1913 com L. socialís Steph. apresenta-se como fato definitivamente estabelecido (Nomura 1913, p. 46; id. 1929, p. 131; Stephenson 1923, p. 98), ao passo que a de L. goto i Nomura mesmo com certos exemplares de L. goto i Hatai 1899 não parece fóra de dúvida. Essa última questão pode aqui ficar de lado, visto como o material presente se aproxima mais a L. go to i Nomura que a L goto $\mathrm{i}$ Hatai. Stephenson mantinha em todos os seus trabathos (p. e. 1923, p. 96, aí literatura; 1930, muitas páginas) L so cialis como espécie independente. Mais tarde, reuniu Michaelsen (1935, p. 100-102), ao comparar material das Índias Neerlandezas com europeu do Elba baixo, L socialis com L. hoffmeisteri e foi seguido, nisso, por Cernosvitov (1939, p. 104- 105).

Algumas das estruturas que levaram Stephenson a separar $L$ socialis de L. hoffmeisteri foram apontadas por Michaelsen (I. c.) como realmente existentes tambêm em $L$ hoffmeisteri mas, descuidadas na diagnose anterior (Michaelsen 1900, p. 43). Restam, porém, vários caracteres, diferentes nas duas espécies, que, embora não discutidos por $\mathrm{Mi}$ chaelsen (1935), constam de descrições recentes. Na base da literatura, não seria admissivel reunir $L$. hoffmeisteri e $L$ socialis Mas, como Michaelsen e Cernosvitov, em oposição a nós, dispuseram de material comparativo, quando reuniram as duas espécies, não conviria aquí, reivindicar a independência de L. socialis Consideramos apenas possivel a sua restituição. Por isso confrontamos a forma atual, que se distingue mais de L. hoffmeisteri que de L. socialis com essas duas espécies, sem embargo de denominarmô-la em conformidade com a sinonimia estabelecida pelas duas autoridades citadas.

Material típico de $L$ h offmeisteri (Ude 1929, p. 82) tem de comprimento 20-50 mm. e 55-95 segmentos; material sulamericano de L. parvus tido por Cernosvitov (I. c.) como idêntico a L. hoffmeisterie publicado sob êste último nome, tem de comprimento $10-20 \mathrm{~mm}$, de diâmetro $450 \mu$ e $50-90$ segmentos. A forma presente é mais comprida, relativamente mais fina e possue mais segmentos, sendo os dados correspondentes: $50-70 \mathrm{~mm}$, $600 \mu$, e 90-210. A diferença entre a nova forma e L. s o c i al i s é menor, embora ainda exista. Reunindo as indicações de Nomura $(1913$, p. 4) e de Stephenson (1923, p. 96) a respeito de L. socialis, obtemos: comprimento 70-100 mm, diâmetro inferior a 1 mm, e 100-150 segmentos.

A julgar por $L$. goto i Hatai, é simples o saco espermático anterior em L. hoffmeisteri; em L. socialis e em forma divergens é duplo. 
As cerdas são em $L$. hoff me isteri 4-8 por feixe (Ude, I. c., material europeu): 4-5 por feixe nos segmentos anteriores e 2-3 nos posteriores ( $p$ arvus $=$ hoffmeisteri material sulamericano de Cernosvitov, I. c.). Em L. socialis chega-se, pela combinação das indicações de Stephenson e Nomura a 6-8 cerdas anteriores, 3-5 médias, e 1-2 posteriores. Na forma aquí em mãos ha pelo menos 7, e até 11 cerdas anteriores, diminuindo o número para trás, até serem 2 nos últimos segmentos. As pontas dos ramos da bifurcação das cerdas são, nos exemplares presentes, algo obtusas, em oposição aos ramos cuspidatos de $L$ hoff $\mathrm{m}$ e is teri As dimensões dos ramos da forma divergens enquadram-se nas variações admitidas para $L$. hoffmeisteri A cerda dum segmento posterior (Fig. 6A) concorda com a figura da cerda de $L$ so cialis (Stephenson 1923, f. 36). A predominância do ramo distal sôbre o proximal nos segmentos anteriores, invertida nos posteriores, foi descrita por Nomura $(1913$, p. 7) do mesmo modo como ocorre na forma presentemente discutida.

Beddard (1895, p. 252) assinalou a bainha do penis de L. hoffme isteri como sendo 6-7 vezes tão comprida quão larga, indicando os outros autores consultados comprimento maior. Dão, p. e., as proporçöes 1 : 8.11 (Michaelsen 1909, p. 41), 1 : 9-13 (Cernosvitov 1939, p. 105), 1 : 10-11 (Nomura 1913, p. 2; Stephenson 1923, p. 97: L. socialis) 1 : 11 (Michaelsen 1900, p. 44), I : 11-12 (Ude 1929, p. 82). Cernosvitov (1. c.) dá $300 \mu$ (parvus) e $580 \mu$ (hoffmeisteri típico) como limites do comprimento, e $25 \mu$ (parvus) e $49 \mu$ (socialis) como extremos do diâmetro. Na forma divergens encontra-se o termo médio da proporção, a saber, $1: 8,3$ muito perto do mínimo verificado anteriormente. máximo da proporção, mencionado pelos autores precedentes, não se acha realizado na nova forma. O diâmetro mínimo da $f$. divergens $46 \mu_{1}$ aproxima-se ao máximo até agora verificado, i. é, $49 \mu_{1}$ em L. socialis $O$ diâmetro máximo de f. divergens $73 \mu_{\text {r é quasi uma }}$ vez e meia tão grande quão o de socialis $(49 \mu)$, alcançando hoffmeisteri típico, segundo a tabela de Cernosvitov (1939, p. 105), apenas $44 \mu$. Em resumo, revela-se a bainha do penis e, com isso, o próprio órgão copulador de L. hoffmeisteri forma divergens como mais grossa que a de $L$ hoffmeisteri típico. Mas, como a bainha é geralmente mais longa, a saber, $400-545 \mu$ contra $300-380 \mu$, permanece a proporção aproximadamente a mesma. 


\section{Limnodrilus udekemianus Claparède 1862}

(Fig. 10, 16)

Limnodrilus udekemianus Beddard 1895, p. 252.

Limnodrilus udekemianus Michaelsen 1900, p. 45.

Limnodrilus udekemianus Ude 1929, p. 82 (literatura), f. 97a.

Comprimento do corpo, em vermes viventes, $30-60 \mathrm{~mm}$, em conservados, $20-30 \mathrm{~mm}$. O diâmetro é de 400-600 $\mu$. O integumento, quer dizer: o tubo músculo-dermático, é relativamente grosso, a saber, de 50-80 $\mu$, nos animais viventes; de 30-60 $\mu_{1}$ nos cortes, referindo-se essas medidas à região não espessada, fóra do clitelo. Na maneira de se enroscarem espiralmente, os vermes comportam-se do mesmo modo como os da espécie precedente. O número dos segmentos varía entre 100 e 160. A côr é, na impressão geral, roxa enegrecida, devendo-se isso às células cloragógenas pretas, combinadas com a pele esbranquiçada e o sângue vermelho. Na região posterior do verme notam-se faixas septais alaranjadas.

O prostômio, mais comprido que largo, apresenta-se como cône de ponta arredondada. Nos primeiros segmentos (II-V), bi-anulados, é o anel anterior mais largo que o posterior. A cintura formada por células glandulares cutâneas, sita ao nivel das cerdas, é menos alta e distinta que na espécie precedente. Na região posterior do corpo dos vermes viventes são os segmentos mais compridos que o diâmetro do verme.

Os feixes das cerdas bifurcadas (Fig. 10 A, B) ocupam, no $2 .^{\circ} \mathrm{seg}$ mento, a zona média do mesmo, deslocando-se, nos segmentos seguintes, pouco a pouco mais para trás. As cerdas são todas incolores, sólidas e bifurcadas, com o nódulo sempre sito ectalmente, mas, nos segmentos anteriores não tanto, quanto nos posteriores. Na zona anterior do corpo contam-se 4-8 cerdas, de comprimento de $120 \mu$, possuindo os feixes dorsais, às vezes, número menor. Do $8 .^{\circ}$ segmento para trás diminue o número das cerdas, ocorrendo do $25 .^{\circ}$ para trás somente $2-3$ por feixe, com $100 \mu$ de longura. Em vermes sexualmente maduros faltam as cerdas ventrais do $11 .^{\circ}$ segmento. Em todas as cerdas é o ramo distal (externo, superior) mais comprido que o proximal (interno, inferior). Nos primeiros segmentos (Fig. IOA) apresenta-se $\circ$ ramo proximal especialmente pequeno; do $8 .^{\circ}$ segmento para trás torna-se algo maior (Fig. $10 \mathrm{~B}$ ) mas, continua sempre menor que o distal.

A faringe extende-se até o fim do $3 .^{\circ}$ segmento; o esôfago, no $4 .^{\circ} \mathrm{e}$ $5 .^{\circ}$ segmento. As células cloragógenas começam no $6 .^{\circ}$ segmento. A rede formada pelos vasos cutâneos não se restringe apenas à metade posterior, mas, torna-se visivel do $30 .^{\circ}$ segmento, aproximadamente, para trás. Cora- 
ções encontram-se somente no $8^{\circ}$ segmento, havendo, portanto, um único par dessas comissuras especialmente dilatadas. Os nefrídios dos segmentos VII e VIII não são providos de células vesiculosas.

O clitelo abrange os segmentos XI e XII, sem que seja muito espessado ou diferenciado do corpo restante pela côr. Os testículos são grandes, formando cada um figura semelhante à letra $S_{i}$ são situados no $10 .^{\circ}$ segmento. Os ovários, maiores ainda e de configuração tambem de $S$, ocupam o 11.0 segmento. Sacos espermáticos no $90^{\circ}$ e do $11 .^{\circ}$ até $\circ 15 .^{\circ}$ segmento são presentes, mas, não foi possivel verificar se o saco anterior é duplo ou impar. O duto masculino pre-atrial, cujo funíl não difere do órgão correspondente da espécie acima descrita, parece mais grosso que em $L$. hoff meisteri forma divergens, por ser mais espessamente revestido pelas células peritoneais. $O$ átrio tem $275 \mu$ de comprimento e $64 \mu$ de diâmetro; a próstata, fortemente lobada, $230 \mu$ de longura e $180 \mu$ de largura. O trecho post-atrial do duto masculino é mais estreito $(25 \mu)$ que o pre-atrial $(28 \mu)$. A bainha do penis (Fig. $10 \mathrm{C})$ é fracamente chitínica, incolor e no corte transversal de forma circular. Na região ental permanece a bainha tubiforme, sem estreitar-se; ectalmente dilata-se rapidamente ao duplo do diâmetro ental, de maneira que termina infundibuliformemente. Com o comprimento de 66-108 $\mu$ e o diâmetro ental de 27-33 $\mu$, revela-se a relação entre a largura e a longura da bainha como sendo de $1: 2,5-4$ As espermatecas são pequenas no material aquí em mãos, claviformes e desembocam com poros circulares no $10^{\circ}$ segmento.

Procedência: 1) Tanque no terrêno da Secção de Ciências Naturais da Faculdade de Filosofia, Ciências e Letras da Universidade de S. Paulo. 2) Em águas pertencentes ao Tieté, cidade de São Paulo (bairro da Lapa).

Embora não se possa esperar concordância absoluta de descrições baseadas em material suląmericano e europeu, e a classificação aquí realizada se ache restrita ao confronto com as diagnoses acompanhadas apenas pela figura da bainha do penis, não consideramos precária a determinação do material presente. Os nossos vermes distinguem-se tanto de $L$ willeyi Nomura (1913, p. I, 34), espécie muito semelhante a $L$ udekemia n us quanto das outras espécies de penis curto. Como carecemos da descrição original e da monografia de Vejdovsky, foi-nos muito util encontrar no trałado de Hayek (1877, f. 369) ilustração da rede circulatória cutânea de L. udekemianus evidentemente copiada de Claparède, que cabe muito bem aos espécimes atuais (Fig. 16). A grossura da pele foi mencionada por Leunis \& Ludwig (1886, p. 772), baseando-se a 3. a edição dêsse livro excelente, no capítulo respetivo, em Claparède e Vejdovsky. A côr. "muito escura" infelizmente não mais indicada por Ude (1929), acha-se as- 
sinalada na resenha de Michaelsen (1909, p. 41). Auto-copulação foi observada nessa espécie.

Distribuição geográfica: Segundo Ude (I.c.) conhece-se L. udekemianus de vários paises européus, tanto de setentrionais (Finlândia, Dinamarca) o centrais, quanto de ocidentais (Irlanda, Inglaterra) e orientais (Rússia). Foi, além disso, encontrado na Sibéria meridional (Altai). Ocorre tambêm nágua salobra.

\section{Sôbre o aparelho circulatório}

\section{2a. A topografia dos vasos}

(Fig. 11-16)

Os vermes da espécie Limnodrilus hoffmeisteri forma divergens possuem, como órgãos circulatórios principais, os seguintes: 1) ○ vaso dorsal; 2) ○ vaso ventral; 3) ○ vaso supra-intestinal; 4) as comissuras laterais, a saber, as anteriores ou celomáticas, as posteriores ou cutâneas e os corações no $8^{\circ}$ segmento; 5) o plexo sanguíneo intestinal. Um vaso subintestinal, indicado por Fuchs (1907, p. 456) como ocorrente normalmente em Limnodrilus p. e., tambêm em $L$ grandiseto sus Nomura (1932, p. 520), falta na forma presente, como em L sociali s (Stephenson 1923, p. 96). Tão pouco podemos confirmar a existência de dois pares de corações, mencionados por Fuchs (1. c.) como característicos de Limnodrilus em oposição a Tubifeix. Tanto Nomura (1913, p. 25) quanto Stephenson (1923, p. 96) descrevem um único par de corações em Limnodrilụs socialis segundo Cernosvitov (1939, p. 105), idêntico a L. hoffmeisteri ocorrendo tambêm um único par em L. motomurai (Nomura 1929, p. 134). Apesar disso, menciona Stephenson, na sua monografia (1930, p. 747). L vejdovskyanus Benham (1903, p. 214) como espécie excepcional no gênero, porque possue apenas no $8 .^{\circ}$ segmento corações. De Limnodrilus hoffmeis teri descreve Cernosvitov (1. c.) dois pares de corações, tendo Claparède, segundo Michaelsen (1935, p. 101), indicado apenas um par no $8 .^{\circ}$ segmento. O material de Cernosvitov tem caracteres de Limnodrilus parvus Southern, espécie incluida por Cernosvitov na sinonimia de $L$ hoff meisteri. Preferindo considerar L. parvus como forma especial de $L$ hoffmeisteri classificamos assim material de S. Paulo (veja p. 167). Este possue corações apenas no 8. segmento, portanto, um único par, existindo no segmento seguinte, no $9 .^{\circ}$, uma alça do vaso dorsal (Fig. 5, g), inconfundivel com os corações grossos do $88^{\bullet}$ segmento. Contrácteis são tam- 
bêm as comissuras finas e serpenteadas nos segmentos $I X$ e $X_{1}$ mas, não são corações.

A dificuldade de verificar a existência ou ausência do segundo par dos corações parece provir do comportamento do vaso dorsal no $9 .^{\circ}$ segmento (Fig. II, d). Aí desce no lado esquerdo, continuando, na forma dive rge n s em posição ventro-lateral, ou, mais para trás, no lado esquerdo, sem voltar para a face dorsal. As descrições de Stephenson (1923, p. 96; 1930, p. 143) relativas a L. socialis são semelhantes, não idênticas, à atual, divergindo a de Nomura $(1913$, p. 21$)$, pois descreve posição ventral do vaso dorsal somente nos segmentos genitais, i. é, IX-XVII. Em L. grandisetosus desce o vaso dorsal nos segmentos IX-X no lado direito (Nomura 1932, p. 519). Na forma aquí em mãos comunica-se o vaso dorsal com o plexo sanguíneo intestinal, tanto nos segmentos anteriores, quanto nos post-clitelares. Na região média e posterior do verme, onde o vaso dorsal (Fig. I $B, d$ ) é situado no lado esquerdo do intestino em $L$ hofffmeis te ri forma divergens veem-se ligamentos musculosos (Fig. $13 \mathrm{~A}, \mathrm{~m}$ ). originados nos septos e inseridos no intestino. Topograficamente correspondem quasi aos músculos septo-dorsovasais de Lumbriculus variegatus (v. Haffner 1927. p. 12), naquela espécie descritos como auxiliadores da obturação do vaso dorsal. Como em Limnodrilus hoffmeis teri forma divergens não se inserem no vaso dorsal, mas, sim, no intestino, não podem exercer a função que thes foi atribuida em $L u m$ briculus variegatus (O. F. Müller).

O vaso supra-intestinal (Fig. $11,12, s$ ) sai do vaso dorsal no $8 .^{\circ}$ segmento, como em L. vejdovskyanus (Benham 1903, p. 214) e L. motomurai (Nomura 1929, p. 134). Em L. gotoi i. é, L. socialis origina-se no $5 .^{\circ}$ segmento (Nomura 1913, p. 22), corre para trás e aí entra novamente no veso dorsal. As figuras acompanhadoras não ilustram êsse curso com toda clareza, descrevendo-o Stephenson (1923, p. 96), na mesma espécie, algo diferente, a saber, presença dum vaso supra-intestinal nos segmentos $\mathrm{V}$ a IX apenas. O capítulo relativo ao vaso supra-intestinal da monografia de Stephenson (1930, p. 143) revela a desconformidade dêsse vaso nos vários gêneros das Tubificidae i havendo, como parece, nem mesmo uniformidade nas diferentes espécies de um gênero. Em todo o caso não está certa a generalização de Fuchs (1907. p. 455) sôbre a existência dum vaso subintestinal em todas as Tubificidae providas de vaso supra-intestinal. Nos dissepimentos anteriores, percorridos na forma presente pelo vaso supra-intestinal, encontram-se, nos septos, os músculos oclusores descritos de Lumbriculus variegatus (v. Haffner 1927, p. 22).

Naturalmente recebe $\circ$ vaso ventral (Fig. $|1-| 3, v)$ todas as comissuras. A origem destas apresenta novamente variações. Em L. hoff $m$ e isteri 
forma divergens saem as comissuras dos segmentos IV-VII (Fig. II. 12,0) do vaso supra-intestinal, do segmento IX para trás (Fig. 13,a), do vaso dorsal. A sua origem é sempre situada na zona caudal do segmento, quasi ao nivel do dissepimento, parecendo tal posição, segundo a literatura, regular nas espécies do gênero em questão. As comissuras dos segmentos anteriores da nossa forma permanecem, no total do seu curso, internamente à somatopleura $e$, por isso, poderiam ser chamadas de comissuras celomáticas. Em L.vejdovskyanus Benham (1903, p. 215 t. 25 f. 12) todas as comissuras ligam os vasos dorsal e ventral. Com isso, corresponde a topografia dos corações, que são comissuras especializadas, em L. ve ¡dovskyanus à de $L$. hoffmeisteri forma divergens pois aquí saem tambêm do vaso dorsal, no meio do 8 . segmento (Fig. $11,12, c)$, um pouco rostralmente à origem do vaso supra-intestinal (s). Em L. socialis e L. motomura i (Nomura 1913, p. 25; 1929, p. 134) saem os coraçōes do vaso supra-intestinal e todas as outras comissuras, do vaso dorsal. Visto como Fuchs [1907, p. 456) atribue às Tubificidae com vaso supra-intestinal sempre corações originados nêste vaso ("supraintestino-pericorda"), examinámos nos cortes a origem dos corações em $L$. h offmeisteri forma divergens antes de afirmarmos que saem do vaso dorsal, não do supra-intestinal.

No material aquí classificado como Limnodrilus hoffmeisteri forma parva Southern constituem os corações (Fig. 5,c) tambêm uma comunicação entre os vasos dorsal e ventral, sem ligação com o vaso supra-intestinal. Trata-se, portanto, na forma divergens e na forma parva de "corações dorso-ventrais" (Stephenson 1930, p. 149), não de "intestinais"

Em animais sexualmente maduros desenvolvem-se as comissuras dos segmentos $|X-X|$ enormemente, enovelando-se e formando alças. Suprem os sacos espermáticos anteriores que se estendem no $9 .^{\circ}$ segmento (Fig. $(1,0)$, os testículos e grupos livres de gonócitos masculinos no $10^{\circ}$ segmento e os ovários do $11 .^{\circ}$ segmento. As comissuras alongadas do $10^{\circ}$ e $11 .^{\circ}$ segmento entram profundamente no saco espermático posterior e no ovisaco, respetivamente. Dessas comissuras são contrácteis as do $9 .^{\circ}$ e $100^{\circ}$ segmento, não aquela que supre o ovisaco, i. é, a do $11 .^{\circ}$ segmento.

Quanto ao suprimento do prostômio (Fig. II) concordam $L$ hoff meisteri forma divergens e L. socialis (Nomura 1913, p. 23). Em ambas as formas bifurca-se o vaso dorsal e os dois ramos, mediocremente sinuosos, entram no vaso ventral. Na forma presente são os vasos celomáticos dos segmentos II e III fornecidos por bifurcação terminal correspondente do vaso supra-intestinal, realizada na zona rostral do $4 .^{\circ}$ segmento. Este segmento é o primeiro com comissuras laterais típicas.

$U_{m}$ vaso unilateral, que liga o vaso dorsal ao ventral, encontra-se naqueles segmentos (Fig. $13, u$ ) cujas comissuras se tornam vasos cutâneos. $O$ 
vaso unilateral possue paralelo no "vaso intestinal ventral" de L. mo tomurai (Nomura 1929, p. 134 f. 2), com a diferença de ligar êsse vaso o plexo sanguíneo intestinal ao vaso ventral.

Os vasos cutâneos (Fig. 13-15,a) participam em Lim nodrilus hoffmeisteri forma divergens da circulação total, como tal foi implicitamente indicado por Nomura (19/3, p. 25 na descrição dos vasos de L. goto $i=L$. socialis). Em oposição a isso, pensa Stephenson (1930. p. 183) que terminam cegamente na pele, tanto em $L$. hoffmeisteri quanto em L. socialis A identidade de L. gotoi e L.socialis está certa; a de L. socialis e de L. hoffmeisteri foi pronunciada por Michaelsen (1935, p. 100). Mesmo abstraindo a questão taxonômica, parece dificil imaginar a terminação cega dos vasos cutâneos em qualquer espécie de Limnodrilus Topograficamente pode sêr, e, evidentemente, é, muito variavel o sistema circulatório das Tubificidae, mas, vasos intra-epiteliais, como o são os capilares cutâneos, sem musculatura própria e situados fóra da musculatura do corpo, não poderiam funcionar, senão comunicassem com a circulação. Na forma presente tal comunicação existe certamente.

Nomura $(1913$, p. 23, 25) separa rigorosamente os vasos celomáticos dos vasos cutâneos. Parece preferivel acentuar que os dois tipos são comissuras laterais reciprocamente vicárias. No objeto de Nomura, em que os vasos celomáticos e os cutâneos saem do vaso dorsal e entram no vaso ventral, revela-se isso mais nitidamente ainda que em $L$. hoffme isteri forms divergens, cujas comissuras 4-7 se originam, como foi dito, no vaso supra-intestinal. Não obstante, pode-se admitir, tambêm na forma aquí presente, a homologia das comissuras anteriores (celomáticas) e posteriores (cutâneas), visto como o vaso supra-intestinal representa apenas uma duplicação do vaso dorsal e a origem, pouco antes do septo, é a mesma, tanto dos vasos celomáticos, quanto dos cutâneos.

Os pormenores do curso das comissuras posteriores (cutânéas) depreendem-se das Figuras 13 e 14. Saem do vaso dorsal, situado no lado esquerdo do intestino, vão aos folículos dos feixes dorsais de cerdas, descem, dentro do celoma, aos feixes ventrais e penetram, através da somatopleura e as camadas musculosas longitudinal e anelar, na epiderme. Percorrem aí onduladamente toda a periferia do segmento, subindo primeiramente no terço posterior do segmento para o lado dorsal, descendo então no terço anterior para - lado ventral, onde continuam para trás. Ainda no lado ventral entram no segmento seguinte, sobem aí novamente, suprindo a pele do terço anterior dêsse segmento, tanto lateral, quanto dorsalmente. Descem perto do dissepimento, mas, ainda no segmento posterior, atravessam o septo ao nivel do vaso dorsal e, continuando a descer até as cerdas ventrais do segmento da 
sua origem, aquí voltam ao celoma, tomando rumo quasi horizontal até desembocarem no vaso ventral.

Em Limnodrilus hoffmeisteri forma divergens é o sistema circulatório cutâneo mais desenvolvido na zona situada rostralmente à região de acrescimo de segmentos, sendo aí o calibre dos capilares a mais amplo de todas as partes do corpo. Em preparações totais de vermes corados com hematoxilina ou carmim são especialmente na dita zona impressionantes as linhas claras serpentinas entre os núcleos epiteliais intensamente corados. Num verme de 170 segmentos começaram no $86 .^{\circ}$ segmento (contagem iniciada no prostômio) os vasos cutâneos como justamente reconheciveis. Na região entre $\circ 86^{\circ}$ segmento e o clitelo perdem as comissuras posteriores com o crescimento progressivo as alças dermáticas, oblitérando-se gradualmente. Como os cortes mostram, o sângue não circula em lacunas epiteliais, mas, sim, em capilares verdadeiros (Fig. 15,a), revestidos por membrana própria, à qual se apõem, internamente, escassas células chatas, provavelmente formadoras dessa túnica íntima.

O plexo circulatório cutâneo de Limnodrilus udekemianus Clap. abrange região mais extensa do corpo que em $L$. hoffmeisteri forma divergens pois já se encontra do $300^{\circ}$ segmento para trás. A saida da comissura cutânea do vaso dorsal e a sua volta para o vaso ventral são em L. udekemianus as mesmas como na forma divergens (Fig. 13). Difere, porém, o curso do vaso no trecho intra-epitelial. Em oposição às duas alças serpenteadas da forma divergens existe em L. udekemianus uma rede de malhas densamente dispostas e formadas por capilares finos, que se anastomosam mutuamente (Fig. 16).

Nos vermes do gênero Limnodrilus o vaso dorsal, provido de musculatura interna, longitudinal, e externa, circular, os dois corações do 8. segmento e as comissuras do $99^{\circ}$ e $10 .^{\circ}$ segmento são responsáveis pela circulação. Esta segue o esquema geral dos Oligochaeta, pois, corre o sângue ventralmente em direção antero-posterior, sobe pelas vias de comunicação entre os vasos ventral e dorsal para êste último, onde corre em direção postero-anterior. O impulso para o movimento no lado ventral é fornecido pelos corações, cuja atuação não somente impele o sângue no vaso ventral do 9.0 segmento para trás, mas, tambêm aspira o sângue no tronco ventral dos segmentos anteriores. Do mesmo modo atuam as comissuras do 9. e $10 .^{\circ}$ segmento. A corrente sanguínea é independente dos movimentos dos septos que se encurvam para diante e para trás, sem influenciar o rítmo das pulsações do vaso dorsal. A questão muito discutida (Stephenson 1930, p. 175) a respeito da participação ativa de outros vasos na circulação poderia ser abordada, em Limnodrilus hoffmeisteri forma diver- 
ge ns da maneira seguinte. Contractibilidade dos vasos maiores existe, visto como ocorrem trechos cheios e vasios em várias partes do aparelho circulatório do animal vivente. As alterações de um dêsses estádios para - outro são, naturalmente, acompanhadas por movimentos do respectivo vaso, que parecem peristálticos. Não se trata, porém, de fenômenos regulares, nem de pulsações rítmicas, mas, antes, de oscilações locais de caracter tônico ou, em certos casos, de movimentos passivos, ocasionados pela musculatura do corpo ou do intestino.

\section{2b. Os corações e as comissuras contrácteis}

(Fig. 17-18)

Tanto as comissuras dilatadas do $8 .^{\circ}$ segmento, os chamados corações, quanto as igualmente contrácteis dos segmentos $\mathrm{IX}$ e $\mathrm{X}$ possuem em Li m nodrilus hoffmeisteri forma divergens estrutura histológica complicada, não descrita, até agora, satisfatoriamente. Os componentes da parede dos corações e das comissuras dos segmentos indicados concordam, de modo que podem ser discutidos simultaneamente. As comissuras tubiformes entendem-se mais facilmente que os corações, cujo curso obliquo (Fig. $12, c$ ) dificuita a orientação dos planos transversal e longitudinal nos cortes.

A preparação total de uma das comissuras mostra um tubo composto de cilindros separados por constriç̧ões (Fig. $17 \mathrm{~A}$ ). Cada cilindro possue na superfície, uma saliência, formando a sucessão dessas saliências uma linha apenas levemente arqueada $e$, por isso, visivel no mesmo lado em certa extensão. Os estudos de Vejdovsky sobre a histologia dos vasos, principalmente das Enchytraeidae e dos Megadrili (1905, 1907), conteem tambêm o coração e as comissuras contrácteis de um representante das Tubificidae, Potamothrix (segundo vários autores llyodrilus) moldaviensis Vejd. \& Mraz. (1905, t. 9 f. 52-55). A figura das "duas alças de vasos laterais" i. é, comissuras (f. $55, a, b$ ), assemelha-se à atual de Limnodrilus e, por princípio, não nos pormenores, explicamos a estrutura da camada externa dos corações e das comissuras contrácteis de Limnodrilus do mesmo modo como foi interpretada por Vejobsky aquela de Potamothrix (I. c., p. 117). Em ambos os vermes trata-se de aneis musculosos, correspondendo cada anel a uma célula. Os pormenores veem-se no corte transversal (Fig. 17 B). Evidencia-se o sarcoplasma de cada célula da musculatura circular formado por colunas, prismáticas pelo achałamento mútuo, granulosas na zona interna $(\mathrm{g})$, vesiculosas $(\mathrm{v})$ perifericamente. Dentro do mioplasma, mas, externamente situado, apresenta-se o grande núcleo (n) da célula musculosa anelar do vaso. As fibrilas (c) ocupam a zona mais interna ou basal da célula. 
Compöe-se, assim, cada célula da musculatura circular das comissuras. contrácteis e dos coraçōes de Limnodrilus hoffmeisteri forma divergens pelos elementos seguintes: 1) Miofibrilas, situadas basalmente: 2) Mioplasma, diferenciado em colunas ou prismas, granulosos na base, vesiculosos na periferia; 3) Núcleo, situado na camada mais periférica. O tipo geral de tal célula musculosa é o nematóide, como se conhece da musculatura do corpo de vários Oligochaeta, nomeadamente de Microdrili, desde as pesquisas de Ratzel (1869, p. 259). Hesse (1893, p. 6; 1894a, p. 395) e outros. Traços especiais residem: a) na diferenciação do sarcoplasma em duas zonas; b) na sub-divisão do sarcoplasma em numerosas colunas. A significação fisiológica dessas duas especializações ignoramos; podemos apenas assinalar a ocorrência de colunas semelhantes na musculatura longitudinal do tubo músculo-dermático e na musculatura das espermatecas da nossa espécie atual. Ao que nos parece, são as pequenas vilosidades ("Zöttchen"h da musculatura do corpo de Tubifex (Ratzel 1869, p. 259, 260 t. 22 f. 16, 17) homólogas às colunas sarcoplasmáticas aquí descritas de L i m nodrilus

De passagem, apenas, seja mencionada a interpretação da estrutura dos corações de Limnodrilus gotoil=hoffmeisteril e de Monopylephorus (=Rhizodrilus) pilosus dada por Nomura (1913. p. 25 f. 17; 1915, p. 22 f. 17). O núcleo da célula musculosa circular considera Nomura como célula possivelmente nervosa; a zona vesiculosa do sarcoplasma, como peritôneo celular; as colunas mioplasmáticas, como "curious layer" de fibrilas contrácteis. As camadas internas, formadas pelas fibrilas. das células da musculatura anelar e pelas da musculatura longitudinal, chama de musculatura circular e longitudinal. Os desenhos são suficientes, faltando, p. e., no "peritôneo celular" todos os núcleos, como realmente não existem, com exceção dos núcleos na periferia do próprio miócito.

O esquema (Fig. $17 \mathrm{C}$ ), que combina cortes longitudinais e transversais, mostra os núcleos $(n)$ da musculatura circular enfileirados, não ao longo do. vaso inteiro, mas, em certa extensão. A camada interna é constituida por fibrilas longitudinais (I), apondo-se a elas amebócitos (Fig. 17 B,a), irregular e escassamente distribuidos. Tão pouco quão em $T u b$ ifex tubifex (Frieda Meyer 1915, p. 593) existe um endotélio vascular ou uma túnica íntima. Sterling (1909, p. 317) pensa que a ausência de endotélio implica na falta de musculatura longitudinal, mas tal opinião mostra apenas que Sterling mal entendeu a exposição de Vejdovsky.

A ausência de núcleos nas fibrilas longitudinais de Limnodrilus discorda dos achados de Vejovsky (1905) em Potamothrix moldaviensis e outras espécies. Como na maioria das suas figuras, desenha Vejdovsky tambêm no corte transversal do coração de Potamothrix 
\{t. 9 f. 52) os "mioblastos intravasais" i. é, as células da musculatura longitudinal dos vasos, providos de núcleos. Segundo v. Haffner (1927. p. 16), que não encontrou tais núcleos em Lumbriculus variegatus, tratar-se-ia nos "mioblastos internos" de Vejdovsky de amebócitos. •Parece-nos dificil admitir essa explicação sem reserva. Figuras como a do coração de Enchytraeus adriaticus (Vejovsky 1905, t. 8 f. 27) provam que o grande mestre distinguia amebócitos e mioblastos, e no corte do coração de Fridericia hegemon (ibid., f. 17), tambêm das Enchytraeidae, - núcleo aparece somente em uma das células da musculatura longitudinal. Por outro lado, existem figuras, como p. e., a da comissura de Rhynchelmis limosella (Lumbriculidae), em que se impõe a explicação de v. Haffner. Poder-se-ia, finalmente, ainda pensar ter Vejovsky cortado, com certa preferência por causa da sua pequenez, animais jovens, talvez no caso do representante das Tubificidae (Potamothrix moldaviensis t. 9 f. 52-54). Os minúsculos núcleos das células musculosas longitudinais dos vasos presentes nos segmentos posteriores $e$, assim, mais jovens, de $\mathrm{Lum}$ bricuius variegatus desaparecem nos anteriores, mais velhos ( $v$. Haffner 1927. p. 15 f. 7 e 8 no texto). No nosso material de Limnodrilus hoffmeisteri forma divergens não existem mais núcleos entre as fibrilas da musculatura longitudinal dos vasos. Isso não quer dizer que não sejam mais frequentes em Potamothrix moldaviensis especialmente em espécimes jovens. Concordância de todos os elementos histológicos dos vasos em diferentes gêneros das Tubificidae não se pode esperar, e, menos ainda, nas várias famílias dos Microdrili.

Do coração estruturado, como foi dito, do mesmo modo como a comissura contractil do 9 . ou $100^{\circ}$ segmento, damos um corte longitudinal (Fig. $18 \mathrm{~A}$ ) e outro para-tangencial (Fig. $(8 \mathrm{~B}$ ), repetindo-se nêles as estruturas descritas. Somente nos corações, não nas comissuras, ocorrem, no ponto em que os mesmos saem do vaso ventral, massas intravasculares de células, provavelmente de função de válvula, como foram por Frieda Meyer (1916, segundo Stephenson 1930, p. 161) encontradas no coração de Tubifex tubifex Os núcleos das células musculares circulares formam no coração de Limnodrilus hoffmeisteri forma divergens uma série ligeiramente ondulada, como foi descrita das comissuras.

\section{2c. O plexo sanguineo intestinal}

(Fig. 19-22)

As lacunas sanguíneas, desenvolvidas ao redor do trato intestinal de muitos Oligochaeta, apresentam, como foi ultimamente realçado por Bhaskaran Nair (1938, p. 57), um dos capítulos mais discutidos da literatura oli- 
goquetológica. Tal interesse poderia causar surpresa, visto que o aparelho circulatório dos Invertebrados não tem, geralmente, atraido os pesquisadores do mesmo modo como outros sistemas, p. e., o celomático e excretório, relacionados com o plano fundamental da estrutura, o nervoso, locomotor e respiratório, fisiologicamente de interesse imediato e o digestivo e reprodutivo, convidativos à análise histológica e citológica. O aparelho de circulação dos Invertebrados é histológica e, mais ainda, fisiologicamente dificil; em animais sistematicamente relacionados mostra grandes diferenças, p. e., dentro das ordens dos Copepoda, Ostracoda e Acarina, possuindo, por outro lado, ordens diferentes, p. e., os Polychaeta e os Oligochaeta, no plexo sanguíneo circum-intestinal, órgão análogo, mas, de estrutura diversa, como se vê pela última descrição do sistema sanguíneo de $\mathrm{S}$ a bella (Ewer 1941, p. 607. f. 9 no texto, p. 609). Se, apesar dos momentos desfavoráveis, a bibliografia a respeito do plexo sanguíneo intestinal dos Oligochaeta possue a extensão aludida, tal não é explicavel apenas pela ocorrência geral dêsse órgão, combinada com variação dos pormenores, tanto nas diversas famílias, quanto nos vários trechos do trato digestivo. Para isso devemos responsabilizar o grande trabalho de Lang (1903), em que completou a teoria do gonorela (Hatschek) pela própria do hemocela, baseada no seio sanguíneo intestinal dos Annelida. Foram, ao nosso vêr, a síntese impressionante de Goodrich (1895) sôbre os celomodutos e as famosas teses de Lang que conseguiram a adesão de muitos zoólogos à teoria do gonocela. Como fonte de informação sôbre o "gonocela" refiro-me às exposições de Heider (1909, p. 307-308; 1914, p. 484-485) e de Stolte (1931, p. 127). A admissão ou rejeição dessa teoria não afeta o conteúdo da teoria do hemocela, se esta fôr restrita à origem das vias sanguíneas dos Coelhelminthes.

O conjunto dos vasos dos Annelida, o trofocela de Lang, origina-se, na opinião dêle, entre o epitélio do intestino, o endoderma ou enteroderma, e - folheto adjacente do saco celomático, i. é, a esplâncnopleura. O sângue circula nêsse espaço, desprovido de epitélio próprio (endotélio ou vasotélio), devido à ação da musculatura, que se desenvolve na face interna do peritôneo visceral. Essa fase inicial dos vasos dos Annelida é representada pelo seio ou plexo sanguíneo no trato digestivo. A discussão das observações relativas à estrutura do seio nos Oligochaeta, aos vasos com êle relacionados e aos elementos intravasais ocupam as páginas 210-218, 235-253 e 268-282, respetivamente, da obra de Lang (1903). A circumcrescência do seio pela esplâncnopleura e, assim, o desenvolvimento dos vasos, como se realiza conforme às ideias de Lang, foi otimamente exposta por Heider (1928, p. 240-24I).

Segundo Lang, seria o sistema sanguíneo dos Annelida um esquizocela no sentido de Huxley (1875, p. 54), originado por delaminação dos epitélios 
intestinal (a parede do gastrocela de Lang) e peritoneal (a parede do gonocela de Lang), inicialmente contíguos. Onde os vasos possuem espécie de endotélio, trata-se de pseudo-epitélio descontínuo, de origem mesenquimática (Lang 1903, p. 196). Hemócitos e outros elementos intra-vasais (válvulas, vasocordão = "Herzkörper", etc.) são projeções celoteliais, quer dizer, evaginações da parede do celoma para dentro do lumen do vaso.

O grande pesquisador dos Oligochaeta, F. Vejdovsky, publicou, logo depois da saida da obra de Lang, dois artigos importantes (1905, 1907). cujos resultados são opostos às conclusões de Lang. Segundo Vejdovsky, existe no lado externo do seio sanguíneo uma membrana vasotelial, formada por células de origem intestinal (endodérmica). Entre o vasotélio e as células endodérmicas de substituição, situadas basalmente no epitélio intestinal existem ligações citoplasmáticas. O hemocela forma-se, destarte, por delaminação intra-endodérmica, e os músculos mesodérmicos circumdam os vasos apenas secundariamente.

As observações embriológicas em Eis en ia (Sterling 1909) e Tubifex (F. Meyer 1915), portanto, em Terricolae e Limicolae, confirmam, nos traços fundamentais, as ideias de Lang, deduzidas da morfologia dos vermes adultos (Stephenson 1930, p. 492-493, 505-506). Não completamente resolvida foi, até agora, a questão: se o seio sanguíneo precede ontogeneticamente sempre aos elementos restantes do aparelho circulatório (Sterling 1909. p. 278; E. B. Wilson 1889, veja v. Haffner 1927, p. 34), como tambêm o problema da origem das formações intravasais.

Cortes de Limnodrilus hoffmeisteri forma divergens (Fig. 19,20) e Peloscolex evelinae (Fig. 21) mostram o plexo sanguíneo (s) atravessado por numerosos pilares ( $p$ ), como foram encontrados em Naididae, p. e., em Chaetogaster diaphanus (L. Dehorne 1916, f. XX no texto) e Stylaria lacustris (Hesse 1893, t. I f. 29; L. Dehorne 1916, t. 2 f. 14, 15), em Enchytraeidae (Vejdovsky 1905, t. I f. I, 15, 25; Freudweiler 1905, t. 12 f. 6) e em Lumbriculidae (v. Haffner 1927. f. 4, 24-26 no texto). Na forma atual de Limnodrilus os pilares são simples, ao passo que em Peloscolex evelina e ocorrem pilares bifurcados ou dois originados separadamente na mesma célula do epitélio intestinal (e). A altura dos pilares varia em indivíduos diferentes de $P$ evelinae, dentro da mesma região do intestino (Fig. 2lA, 2|B), seja devido à idade, seja ao estado fisiológico. Visto que os pilares são. ao nosso vêr, continuações das células intestinais, não parece provavel ser a diferença da altura causada por estados de contração diferentes. Os pilares não são musculosos; a estriação longitudinal, visivel nas figuras atuais, é frequente, mas, não constante. 
Visto passar nos Microdrili o sistema dos canais sanguíneos, formado pelos pilares, presentes somente nos segmentos anteriores, ao seio dos segmentos posteriores, recomenda-se falar com Stephenson (1930, p. 140, 152) em "plexo sanguíneo" Stephenson chama de "intestino" apenas aquela região do trato alimentício que sucede ao esôfago dos Microdrili e à moela dos Megadrili, respetivamente. Por isso chama o plexo de "plexo alimentício" para, destarte, poder incluir o plexo esofágico. Como preferimos o termo "intestino" para designar o tubo digestivo inteiro, e "intestino médio" para o trecho post-esofágico, o "intestino estomacal" de Vejovsky, podemos falar em "plexo intestinal"

Os pilares, assim denominados, pela primeira vez, por v. Haffner (1927, p. 10) foram considerados por Vejovsky (1905, p. 88) como prolongamentos das células intestinais, dando Freudweiler $(1905$, p. 388, 412), aluna de Lang, interpretação idêntica. L. Dehorne (1916, p. 57, 83) fala até em capilares intra-epiteliais, delimitados pelos pedúnculos das células do epitélio intestinal e a membrana basal dêste último (p. 156-157. explicação das figuras 14 e 15 da est. 2). Deixando por enquanto de lado a questão da membrana externa do plexo, realçamos da exposição de L. Dehorne a falta de quaisquer dúvidas acerca da natureza dos pilares; são, para a dita pesquisadora, pedúnculos das células intestinais, ramificados, às vezes (f. $X X$, no texto), e dando, assim, origem a processos tênues. Essa descrição, menos a passagem relativa à membrana externa, podemos confirmar completamente: o sângue penetra entre as células individuais do epitélio do intestino, as quais possuem carater amibóide, emitindo processos compridos. Na região intestinal pesquisada em. $\mathrm{P}$ elos $\mathrm{col}$ e $x$ e $\mathrm{Li} m \mathrm{n} \circ \mathrm{drilus,}$ sita entre $06 .^{\circ}$ e $\circ 15 .^{\circ}$ segmento, atingem os pilares, na sua maioria, a camada limitrofe do intestino, quer dizer, a esplâncnopleura (Fig. 21), caraterizada pelo revestimento de células cloragógenas (c). Onde a musculatura esplâncnica, muito reduzida na zona desenhada de $\mathrm{P}$ e I o s c o I e x e $v$ eli $\mathrm{n}$ a e se acha fortemente desenvolvida (Fig. 19), tocam os pilares (p) nos elementos mais próximos do intestino, i. é, a musculatura intestinal circular (m).

As observações de Sterling (1909) a respeito das membranas basais do plexo sanguíneo intestinal das Enchytraeidae, uma interna, intestinal, e outra, externa, peritoneal (p. 30l, 310), contrastam com as verificações que Vejdovsky realizou na mesma família. Todavia, encontrou tambêm Sterling (I. c., p. 3I5) em Eu e n chytra eus bis e tos us Bretscher (gênero duvidoso; Ude 1929, p. 71) prolongamentos das células intestinais, que atravessam o plexo sanguíneo. 
Sem mencionar as opiniões de Freudweiler, Sterling e L. Dehorne, concordantes com a de Vejdovsky quanto à natureza dos pilares, explicou-os v. Haffner (1927. p. 35) dum modo absolutamente diferente. Vê nêles produtos da esplâncnopleura, cujas células desenhou ao redor do plexo da região posterior de Lumbriculus variegatus (f. 24-27, Mz) de tal modo que cada pilar completo, i. é, atravessador do plexo inteiro, se acha em contato com uma célula situada na circunferência externa do plexo. A f. 25, desenhada com imersão, mostra dois pilares como continuações do citoplasma das células peritoneais respetivas, ao passo que os pilares se demarcam contra as células intestinais. As células da esplâncno. pleura formam, segundo v. Haffner, tanto os pilares, quanto a fina membrana externa do plexo intestinal. Sem material de $L$ u m b r i c u I u s não se pode discutir a interpretação de v. Haffner, unicovamente exposta e ilustrada por boas figuras. Contrasta inteiramente com a opinião de Vejdovsky, Freudweiler e L. Dehorne, que vale, por certo, tambêm para as espécies de $P$ eloscole $x$ e $L i m$ nod $r i l$ u vistas aquí. A continuidade entre células intestinais e pilares é indubitavel (Fig. 19, 21). e células apostas ao lado interno da esplâncnopleura, que poderiam ser responsabilizadas pela formação dos pilares, não existem.

A disposição anelar dos pilares ao redor do intestino corresponde aos aneis da musculatura circular (Fig. 19, m). A concentração do sângue em faixas longitudinais do verme total evidencia-se, nos cortes tangenciais (Fig. 20). pela direção longitudinalmente acentuada das lacunas entre os pilares, de maneira que a região esofágica se apresenta aos quadradinhos, devido às fibras musculosas longitudinais e circulares.

A ontogênese da membrana externa do plexo sanguíneo ignora-se ainda (Stephenson 1930, p. 505). O gráu de nitidez dessa membrana depende do desenvolvimento, muito variado nos vários trechos do intestino, da musculatura esplâncnica. Assim, a membrana externa do plexo é visivel na Fig. 21, onde não ocorre musculatura intestinal no trecho desenhado, ao passo que na Fig. 19, com musculatura esplâncnica grossa (m), nada se vê da membrana externa. O aparecimento variavel da membrana externa do plexo sanguíneo intestinal já indica não se tratar de elemento próprio, duma espécie de túnica íntima, do piexo, mas de estrutura pertencente à camada aposta ao intestino. Essa camada é a esplâncnopleura, diferenciada no lado aposto ao intestino em musculatura intestinal, no outro lado, em determinadas zonas, em células cloragógenas. A membrana basal das células cloragógenas é a membrana externa do plexo sanguíneo intestinal. Assim, não podemos, com Vejobsky, considerar a membrana externa como de origem endodérmica, nem, com L. Dehorne (1916), falar em plexo sanguíneo intra-epitelial. 
membrana externa do plexo pertence, tão bem quão os outros elementos que circumdam o intestino, ao sistema celomático, de origem mesodérmica, mais exatamente, endomesodérmica. Embora nem sempre se destaque nitidamente a membrana basal das células cloragógenas, e, assim, o plexo careça, em certos trechos, de membrana externa, esta é, onde ocorre, sempre contígua às células cloragógenas ou, em outras regiões do intestino, às células simples da esplâncnopleura.

Para que pudesse ser admitida a teoria de Lang (1903) e considerado o plexo sanguíneo intestinal como tipo originário dos vasos dos Annelida, o plexo deveria ser ontogeneticamente o primeiro elemento do aparelho circulatório, e os outros vasos deveriam diferenciar-se dêle. Senão fosse assim. a ideia de Lang valeria apenas no campo filogenético. Na literatura figura, porém, o pensamento de Lang como resumo dos fatos. Essa opinião é tão universal (Heider 1928, p. 240; Stephenson 1930, p. 505), que v. Haffner (1927. p. 34), ao mencionar dois casos de precedência ontogenética do vaso ventral sôbre o plexo, recomenda novo exame dos achados respetivos. Quanto aos Oligochaeta, reside a base principal da doutrina comumente adotada no trabalho de Frieda Meyer $(1915,1916)$, realizado em Tub if ex tubifex (Müll.). Dessa pesquisa dispomos apenas da nota preliminar (1915), de maneira que ignoramos de que região do embrião provem o corte transversal, reproduzido por Stephenson (1930, f. 213). Nêsse corte, é verdade, existe, como único elemento do aparelho circulatório, o plexo. Mostrando, porém, o intestino, nessa figura, já o lume perfeito, o embrião deve ser mais adiantado que o de Limnodrilus hoffmeisteri forma divergens destituido ainda de lume intestinal, da Fig. 22.

A esplâncnopleura acha-se ainda intimamente aposta ao enteroderma, ao longo do embrião inteiro, faltando, assim, a fenda esquizocélica que dá origem ao plexo sanguíneo. Os primórdios do intestino médio são visíveis, de maneira que a fase concorda com a dos cortes transversais dos estádios Q-R de Tubifex tubifex (Penners 1923, t. 14 f. 28, 29). Do mesmo modo como Penners (1. c., p. 285), vimos nessa fase, dorsalmente ao sistema nervoso, na esplâncnopleura, uma acumulação de células que forma um cordão sólido no terço anterior do verme (l. c., fig. Z no texto, p. 282). Esse cordão representa o primórdio do vaso sanguíneo ventral. Embora não disponhamos de fases ulteriores, já podemos notar que a aparição do vaso sanguíneo ventral precede à do plexo sanguíneo. Penners abordou, como êle mesmo disse, só brevemente a ontogenia dos vasos sanguíneos e, assim, não discutiu a discrepância entre a sua observação e o achado da aluna de Lang.

Não obstante, devemos acrescentar Limnodrilus e Tubifex aos casos de origem "atrasada" do plexo sanguíneo, reunidos por v. Haffner 
11. c.). Naturalmente fornece em Limnodrilus como em todos os Oligoquetos, o mesoderma, ou, melhor, o endomesoderma, o material dos vasos. O primeiro órgão circulatório é, em Limnodrilus hoffmeisteri forma divergens, o vaso ventral, não o plexo sanguíneo intestinai. Dando-se o mesmo em Tubifex tubif ex, existe, inegavelmente, certa distância entre a teoria do hemocela e os fatos ontogenéticos. A origem esquizocélica do aparelho circulatório dos Annelida em geral não pode, evidentemente, ser provada em cada caso concreto. Ocorrem vermes, cujo plexo intestinal de natureza esquizocélica se forma depois de outro órgão do sistema circulatório, portanto, não reconduzivel ao plexo. Se o plexo fosse mantido como tipo filogeneticamente mais primitivo dos órgãos circulatórios dos Annelida, opinião ventilada na tese da Dra. Faulkner (1930, p. (64-166), os casos da sua formação "atrasada" deveriam ser considerados como fenômenos cenogenéticos.

\section{Sôbre os casulos e o ovário}

Os casulos de Tubifex tub ifex (Müll.) foram descritos por Dixon (1915, p. 85-86) e Welsh (1921, p. 191-194) e comparados por Penners (1933, p. 93-95) com os de Limnodrilus hoffmeisteri forma typica e L. udekemianus. Na forma divergens (Fig. 23) e em Tubifex tubifex (Fig. 24) é simples a parede dos casulos como na forma típica de L. hoffmeisteri. No material de Penners encontravam-se os casulos envolvidos por capa de muco, que grudava tantas partículas da vasa que os próprios casulos se tornavam intransparentes. Nos casulos recemdepositados da forma divergens e de Tubifex tubifex permanece - manto mucoso nos primeiros dias transparente, permitindo assim, contar os ovos dentro do envólucro. Mais tarde, a capa do casulo da forma divergens incrusta-se com corpúsculos alheios, e o casulo torna-se opaco.

No material presente distinguem-se os casulos de Limnodrilus hoffmeisteri forma divergens (Fíg. 23) dos de Tubifex tu b ife $x$ (Fig. 24) principalmente pela forma. Os primeiros são asimétricos, com uma metade mais grossa que a outra; os segundos teem forma de limão. As figuras de Ditlevsen (1904, p. 473 t. 18 f. 9, 14) dos casulos de Tubifex tubifex e Limnodrilus claparèdeanus mostram o mesmo. O botão obturador, futuro orifício do casulo, é arredondado na forma divergens ligeiramente dilatado para fora em Tubifex tubifex As medidas sāo: comprimento até $1350 \mu$ (forma divergens) $750-(200 \mu$ (tubifex): diâmetro máximo $540 \mu$ (forma divergens), 580-680u (tubifex): os ovos (1-10, divergens; 1-5, tu 
bifex) teem $440 \mu$ de comprimento (forma divergens). $400-440 \mu$ (tubifex); e $390 \mu$ de diâmetro (forma divergens), 280-320 $\mu$ (tu bifex). O número de ovos pode, em $T u b i f e x$ tubifex, alcançar 17 (Welsh 1921, p. 192), mas, na população de São Paulo, composta por indivíduos relativamente pequenos, não houve mais que cinco dentro de um casulo.

Uma vez, foi um casulo de 3 ovos da forma divergens furado durante a manipulação, sem que tivesse sido possivel reconhecer o orifício causado artificialmente, mesmo com aumento de 100 vezes. Quando foi exercida ligeira pressão sôbre êsse casulo, escorreu um ovo, que nágua se tornou novamente esférico e continuou a se desenvolver normalmente. Embora essa plasticidade extraordinária provavelmente não seja a mesma nos ovos de todos os Limicola, p. e., nas Naididae, onde ocorrem, no gênero Dero ovos com glebas vitelinas consideravelmente maiores que em Limnodritus o processo descrito concorda bem com as observações de Vejdovsky (1876a, p. 354-355) sôbre a capacidade de os ovos de Rhynchelmis limosella Hoffm. (Lumbriculidae) passarem entre os vários órgãos do corpo e sairem pelas fendas estreitas que constituem, nessa espécie, os orifícios externos dos ovidutos.

Os ovários (Fig. 26 A) de Limnodrilus hoffmeisteri forma divergens correspondem ao tipo regularmente encontrado em Tubi fex tub ifex (Ratzel 1868, p. 568 t. 42 f. 3) e por Hesse (1894, p. 359; 1894a, p. 425-426) verificado em Tubificidae, Enchytraeidae, Lumbriculidae e outros Oligoquetos, pertencendo às espécies pesquisadas por Hesse tambêm Limnodrilus udekemianus (l. c., p. 426). Os gonócitos femininos ocupam em tais ovários zonas que se sucedem do dissepimento 10/11 para trás. A forma geral do ovário da espécie presente lembra um $S$, más, um $S$ encurvado em vários planos sagitais diferentes, de modo que a sucessão das zonas somente pode ser depreendida da combinação reconstrutiva dos cortes seriados. Dificultam ainda a orientação, nomeadamente na região periférica do ovário, as alças do duto eferente e cordoalhas de tecido mesentérico que atravessam o ovário $e_{1}$ assim, tornam indistinta a sucessão das zonas.

A estrutura do duto eferente oferece, aliás, na região aludida, aspeto tão singular, que não pode ser passada em claro. As células deveriam ser descritas, ou como disciformes e perfuradas pelo lume do dúto, que, nêste caso, seria intracelular, ou como aneis completos. Em Tubifex tubi fex ocorre estrutura igual (Stephenson 1930, p. 346). Somente o desenvolvimento poderia esclarecer sôbre a natureza, intracelular ou intercelular, do duto; a julgar pelo trabalho de Gatenby (1916, p. 320-326) sôbre a 
ontogênese do órgão correspondente de Tubifex tubifex, que começa como corda sólida, seria intracelular na espécie atual. Os núcleos, dos quais apenas um ocorre em cada corte transversal, são semilunares e todos situados no mesmo lado (Fig. 25). No corte longitudinal, os limites entre as células condicionam estriação transversal do duto. A circumferência do lume é provida de cílios; a parede do duto é externamente coberta por escassas células peritoneais. Essa disposição encontra-se nas duas formas de $L i m n \circ d r i l u s h$ of $f m$ e $i s t e r i$ aquí pesquisadas, tanto na forma diverge ns quanto na forma $p$ a $r v a \quad E m ~ L$ u d e k e m i a n u s há 2-3 núcleos por corte transversal; em Tubifex tu b ifex (Gatenby 1916, p. 328 t. 24 f. 17 F.), cinco.

$\mathrm{Na}$ zona germinativa (ou multiplicadora), do ovário (Fig. 26B, I) formam os gonócitos femininos, que consideramos como oogônias (Fig. 26 $B$, o), um sincício ou, pelos menos, são os limites intercelulares muito indistintos. Entre as oogônias penetram, do dissepimento $10 / 11$, que é a base do ovário, algumas poucas células chafas, de caracter peritoneal (Fig. 26 $B$, p.). O número dessas células pode ser avaliado pela contagem seguinte: 2-3 cortes da zona germinativa, com $6 \mu$ de espessura, conteem I célula peritcneal, em 4-5 vêem-se 2, em 6-8 cortes, 3 dessas células. São, assim, escassas demais para poderem constituir "estroma" ovárico.

Como a aparência geral do ovário das Lumbricidae (Heumann 1931, f. I) não concorda com o aspeto do ovário de $L \mathrm{i} m \mathrm{n}$ od $\mathrm{r}$ i $\mathrm{tus}$ assim difere tambêm, citologicamente, a zona germinativa do ovário de $\mathrm{L}$ i m nodrilus da zona inicial do ovário das Lumbricidae. Nos vermes da dita família não se pode falar em zona germinativa, porque os gonócitos da região inicial são oócitos na interfase presindética. As divisões das oogônias devem-se ter realizado já no peritôneo. A ausência de metafases e anafases $e_{1}$ mais ainda, o volume uniforme dos gonócitos nas duas primeiras zonas do ovário das Lumbricidae permitem reconhecê-las como zonas presindética e sináptica. Na figura dada por Hesse (1894 a, t. 25 f. 30) do ovário de $\mathrm{L} \mathrm{u} \mathrm{m} \mathrm{b} \mathrm{r} \mathrm{i} \mathrm{c} \mathrm{u} \mathrm{s} \mathrm{faltam} \mathrm{tambêm} \mathrm{mitoses} \mathrm{unívocas,} \mathrm{e.}$ assim, a ilustração, exata como todos os desenhos de Hesse, não justifica - texto. "Na zona de multiplicação encontra-se uma divisão nuclear ao lado da outra e, pelạ coloração mais escura das figuras de divisão, reconhece-se essa zona dos cortes muito nitidamente" Em conformidade com as ideias daquêle tempo, tem Hesse, evidentemente, considerado como figuras de divisão nuclear os novelos sinápticos.

No ovário de Limnodrilus existe zona de multiplicação ou de divisão das oogônias (Fig. 26 B, 2), sendo absolutamente certas as mitoses, das quais uma metafase foi marcada na Fig. $26 \mathrm{~B}(\mathrm{~m})$. Na zona seguin- 
te (Fig. 26 B, 26 C, 3) vê-se ainda o carater sincicial do conjunto dos gonócitos, cujos citosomas são pequenos e pouco tingíveis. Células peritoneais faltam nessa zona completamente. O núcleo dos oócitos de I. ${ }^{\mathrm{a}}$ ordem. como os produtos da divisão das oogônias devem ser chamados, apresenta-se com o retículo presináptico. Primeiramente (Fig. 26 B, 26 C, 3a) são núcleos protobróquios, em zona mais periférica, mas, endentada com a precedente, núcleos reticulados, que correspondem ao "unravelling stage" de Wilson (1934, p. 539). O desenvolvimento da grande maioria dos oócitos não progride muito além dessa fase, entram apenas no $1 .{ }^{\circ}$ período de crescimento, mas, depois, degeneram (Fig. 26 D, 5).

No primeiro período de crescimento delimitam-se os oócitos e, pelo aumento ainda modesto do seu volume, começam a afastar-se uns dos outros. As modificações da cromatina, a sinapsis (Fig. 26 C, s), agora realizadas, não estudámos nos pormenores, porque os numerosos cromosomas não oferecem figuras citologicamente instrutivas.

Geralmente assumem os oócitos na zona marginal interna (Fig. 26 A), - aspeto típico do $2 .^{\circ}$ período de crescimento, com aumento consideravel do volume do gonócito, com núcleo pálido, vesiculoso e nucléolo grande, acompanhado por 3-4 globos de cromatina menores. Visto que os vasos topograficamente vizinhos do ovário (Fig. $26 \mathrm{~A}$, v). i. é, as comissuras do 11.0 segmento, tocam no bordo externo do ovário, o crescimento dos oócitos no bordo interno não se pode explicar pela posição favorecida, no sentido da interpretação de Stolte (1934, p. 90 e seg.) a respeito do crescimento do oócito no ovisaco de Stylaria lacustris (L.).

Antes de discutirmos a alimentação do oócito, assunto principal do nosso estudo do ovário de Limnodrilus, seja esboçada, rapidamente, a sorte futura do oócito. Durante a sua permanência no conjunto ovárico, o ooplasma é basicromático, começando apenas a mudança para a fase oxicromática pouco antes de se soltar o oócito. No ovisaco, onde ainda cresce, o oócito tem sempre plasma oxicromático. Tambêm no ovisaco começa a l. a divisão de maturação, contando-se ca. de 50 cromosomas, de tamanho algo diferentes.

A respeito do crescimento dos oócitos das Tubificidae não ha unanimidade na literatura. A opinião, infelizmente relatäda por Stephenson (1930, p. 455), interpretou o crescimento do oócito dum modo muito singular. Confluência dos citosomas e núcleos de vários oócitos seria responsavel pelo. volume definitivo do oócito no fim do $2 .^{\circ}$ período de crescimento. Tal processo, incompativel com as ideias citológicas sôbre a constância do número dos cromosomas, sôbre a individualidade dos mesmos, etc., constituiria fenômeno extraordinariamente estranho. No material, em que foi des- 
crito, I I yod rilus b a varicus Oschmann, ainda não foi reexaminado, mas, sim, em Tubifex tubifex (Müll.), cuja oogênese foi estudada por um aluno de Schleip (Loewenthal 1922). Segundo êste autor, parece-se o quadro histológico do ovário de $T$ u b i f e $x$ t u $b$ i f e $x$ de tal maneira com o correspondente de $\mid 1$ yod $r i \mid$ u s b a varicus que a "confluência de núcleos e células" inexistente em $T$ u b if e $x$, pode ser considerada como definitivamente refutada.

Desde o fim do primeiro período de crescimento, quando os ovos futuros, que continuam crescendo, e os outros oócitos, que acabam degenerando, se distinguem nitidamente, chama Loewenthal (1922, p. 232 e seg.) os oócitos supérfluos, repetidamente, de "células alimentícias" (Nährzellen), sem, porém, indicar, como alimentam o futuro ovo durante o segundo período de crescimento. O autor aponta, corretamente, que o crescimento mais intenso dos futuros ovos e a degeneração dos pequenos oócitos não se processam sincrônicamente. Mas, tal simultaneidade seria de se esperar, se os oócitos parados no $1 .^{\circ}$ período de crescimento contribuissem para a acumulação de material das células-irmãs, entradas na 2. ${ }^{a}$ fase de crescimento. Notando Hesse (1894, p. 359) no ovário de $L$ u m b r i c u I u s v a $r$ i e $\mathrm{g}$ a $\mathrm{t}$ u $\mathrm{s}$ algumas células degeneradas na zona de crescimento, supôs tratar-se nelas de oócitos, à custa dos quais os outros se aumentaram; do mesmo modo, parece ter Loewenthal falado em "células alimentícias" porque $\circ$ processo suposto por Hesse ocorre frequentemente no reino animal.

Não há, porém, indícios morfológicos duma contribuição dos oócitos supernumerários para o crescimento dos gonócitos-irmãos, nem no objeto de Loewenthal, $T u b$ if ex $t u b$ if ex nem em $L i m n o d r i l u s$ hof $f m e i s t e r i$ forma divergens Onde quer que os pequenes oócitos se aponham aos grandes, crescentes, p. e., no caso da Fig. $26 \mathrm{D}$, onde um processo (e) dum oócito no 2. período de crescimento penetra no meio de muitos oócitos parados, nunca se percebe alteração no citoplasma ou no núcleo das células menores.

Apesar de faltarem quaisquer sinais de função alimentícia dos oócitos parados, ainda não podemos adotar as palavras de Michaelsen (1928, p. 56): "O desenvolvimento dos ovos processa-se nos Oligoquetos de modo muito diverso. Em parte é solitário, em parte, alimentar. Formação solitária do ovo encontra-se na maioria das Tubificidae e nas Lumbriculidae. Os oócitos, oriundos das oogônias, crescem no conjunto do ovário, sem usar, ao que parece, o auxullio de outras células vizinhas" Ao nosso vêr, vale essa descrição somente para o primeiro período de crescimento, em que a ovogênese é, realmente, solitária. No segundo é alimentar, mais exata- 
mente, na terminologia de Ankel (1933, p. II), auxiliada por células foliculares (Fig. 26 C, 26 D, f). Já falámos acima dos mesentérios que atravessam a região periférica do ovário. Tal tecido de suspensão mantem igualmente as comissuras circulatórias da região genital na sua posição. Das cordoalhas mesentéricas proveem células chatas que cobrem os grandes oócitos no bordo interno do ovário. O crescimento mais intenso dos oócitos no 2. período de crescimento coincide sempre com cordoalhas de tecido mesentérico. Embora sejam inconspícuas as células do próprio folículo, podem conduzir o material necessário para o oócito. Em L u m bri culu s v a r i e g a t us verificou Hesse (1894, p. 360) tambêm tecido peritoneal na região periférica do ovário. Nessa espécie provem do dissepimento que segue àquele em que o ovário se origina. Em Limnodrilus hoffmeisteri forma divergens são cordoalhas de tecido semelhante, mas, são livres, independentes do septo seguinte. Sem aludir na procedência ou na função do envólucro peritoneal, Loewenthal menciona-o no texto (1922, p. 232-233), desenhando-o, corretamente, apenas nas zonas periféricas do ovário (t. 14, f. 4, 5, 6), onde cobre os oócitos no $2 .^{\circ}$ período de crescimento.

No ovisaco volta o oócito da espécie atual ao crescimento solitário, aproveitando-se, sem interferência de células auxiliares do material levado pelas comissuras do $11 .^{\circ}$ segmento à parede do ovisaco. No sistema dos tipos de crescimento ovular (Jörgensen 1913, p. II) pertence $L$ i m $n$ o drilus hoffmeisteri forma divergens ao tipo combinado, caracterizado pela sucessão de duas modalidades diferentes.

\section{Sôbre o gênero Tubifex}

(Estampa VIII)

Quanto ao órgão copulador e à próstata, concordam, por princípio, as espécies do gênero $T$ u b i f e x Lamarck $1816 \mathrm{com}$ as do precedente. As cerdas são, geralmente, diferentes, pois ocorrem, nas espécies de $T$ u $\mathrm{b}$ i $\mathrm{f} \mathrm{e} \mathrm{x}$ nos teixes dorsais, pelo menos nos dos segmentos anteriores, cerdas capilares (pilırormes) ao lado das bifurcadas. Tornam-se, destarte, os feixes dorsais diferentes dos ventrais, em oposição à igualdade dos mesmos nas espécies de $\mathrm{L} \mathrm{i} \mathrm{m} \mathrm{nod} \mathrm{rilus} \mathrm{Ocorrendo} \mathrm{entre} \mathrm{as} \mathrm{cerdas} \mathrm{bifur-}$ cadas dorsais, no gênero $T$ u b i f e $x$ algumas de terminação pectinada, permanece a diversidade aludida mesmo nos casos de ausência das cerdas piliformes em certas espécies de $T$ u $b$ i $f$ e $x$ Foram, porém, nos últimos anos, descritos dois casos excepcionais, a saber, Tubifex 
o chridanus forma variabilis Hrabe (1931, p. 20) e T I a c ustris Cernosvitov (1930, p. 101). A primeira forma passa por exemplares intermediários à forma ty $\mathrm{pica}$ de $\mathrm{T}$ och ridanus, esta última com cerdas capilares e pectinadas. Tu b ife $x$ la custris porém, ainda discutido mais adiante, não pode, pelas cerdas, ser diferenciado genericamente. Resulta disso a necessidade de procurar nova sistematização dos dois principais gêneros da família, ambos carecentes de revisão monográfica.

Gêneros vizinhos, em virtude do penis e da próstata, são: I) $P$ e I o scolex (veja p. 155) com papilas cutâneas; e 2) Ilyodrilus Eisen 1879. O último gênero difere de $\mathrm{T} \mathrm{u} \mathrm{b}$ if ex principalmente, pelo comprimento do duto eferente em relação ao átrio. Em II y o d ril u s o átrio é tubiforme, mas, largo; o duto, mais curto que êste, às vezes, quasi rudimentar. Em $T$ u b if ex iguala ou ultrapassa o comprimento do duto ao do átrio.

Hrabe (1931, p. 21) propôs subdividir o grande gênero Tubifex. reivindicando, como denominação sub-genérica, o nome $\mathrm{Ps}$ a $\mathrm{m} \mathrm{m}$ or y $\mathrm{c}$ t e s Vejdovsky 1875 para as espécies com ampola do átrio esférica ou piriforme, em oposição ao sub-gênero Tubifex, com átrio claviforme ou fusiforme. Entre os pormenores da chetotaxia, auxiliadores da dita subdivisão, parecem ser as cerdas esperrnatecais, acompanhadas por glândulas especiais, os mais significativos. Novamente, porém, impossibilita $T u b$ if ex I a c u s $+\mathrm{r}$ i s Cernosv. a separação rigorosa, pois possue cerdas espermatecais com glândulas e átrio, sem dúvida, descrito como alongadamente piriforme, mas, na figura (1. c., f. 75) nitidamente mais semelhante ao tipo comum de $T u b$ ifex que ao de Psam moryctes

As cerdas de T. lacustris do lago Titicaca, como foi dito. não distinguem a espécie de qualquer outra do gênero $L i m n \circ d r i l$ u s $O$ aparelho masculino justifica, todavia, a classificação em $T$ u b i f ex mas, a espécie ocupa aquí posição "rather anomalous" (Cernosvitov 1939, p. 103). Sumariando os vários caracteres morfológicos de $T$ l a c u s tris podemos chamar a espécie de "tipo coletivo" Muito mais que os "tipos primitivos" quasi sempre considerados por outros autores como "tipos secundariamente simplificados" apresentam os "tipos coletivos" sinais de antiguidade. Tal interpretação de $T$ u b i f e $x$ l a c u stris concorda com a isolação do planalto do Lago Titicaca desde o Miocêno (Moon 1939).

Ao achado da primeira espécie sulamericana do gênero $T$ u b i $f$ e $x$ encontrada nas zonas sub-litoral e profunda do Lago Titicaca, opõe-se a verificação da segunda, Tubifex tubifex (Müll.), nos subúrbios da cidade de São Paulo. Alị, espécie endêmica, morfologicamente de caracte- 
res evidentemente antigos, de distribuição possivelmente restrita; aquí, espécie típica do sub-gênero $T$ u $b$ i $f$ e $x$ e de distribuição muito vasta. $\mathrm{Em}$ águas do sistema fluvial platense foram até agora realizadas duas coTheitas de Oligoquetos (Cordero 1931: Cernosvitov 1937), sem que T u b i $f$ e $x+u b i f$ e $x$ tenha sido encontrado. Isso, naturalmente, não quer dizer que a espécie ocorre apenas nos dois pontos, em que agora foi constatada. Explorámos, por enquanto, somente poucas das águas em São Paulo e arredores. $T u b$ if ex $t u b$ if e $x$ poderia ser comum em todo o sistema do Tieté. Provas avulsas, mesmo numerosas, não proporcionam alguma afirmação negativa, porque distribuição homogênea dum verme límnico não se pode esperar na área urbana, em parte pobre em tais animais, devido aos "lambarís" e "guarús espalhados pelo Serviço Sanitário. Somente busca sistemática poderia demonstrar se a ocorrência de $T u$ b if ex t u b i f e x em São Paulo é realmente rara.

Se assim fosse, tratar-se-ia talvez de importação acidental. As oportunidades para tal não faltam. Peixes economicamente interessantes, como a carpa, e outros, ornamentais, foram introduzidos da Europa e America do Norte, ambas habitadas por $T$ u b i f e $x$ t u b i f e $x$ assim como "fango" da Itália foi importado para fins terapéuticos. Seja espécie autóctone ou introduzida, constitue $T u b$ i $f$ e $x+u b$ i f e $x$ elemento faunístico valioso para vários campos do nosso ensino e estudo zoológicos, em virtude de ser animal "estandardizado", monograficamente descrito (Dixon 1915) e pesquisado tanto fisiologicamente (Alsterberg 1922; 1924; Dausend 1931), quanto embriologicamente (Welsh 1921; Penners, desde 1922 , muitas publicações), para somente mencionar alguns dos trabalhos principais. A única dificuldade da manipulação reside na classificação certa. Se o registro das Tubificidae de São Paulo estiver, uma vez completo, a espécie poderá ser determinada pelas cerdas. Nas condições atuais, porém, o fisiólogo ou farmacólogo não poderia trabalhar seguramente com material, em que não houvesse alguns exemplares sexualmente maduros. A resenha dos Oligochaeta do Lago Titicaca contem exemplo significativo da indispensabilidade dos órgãos reprodutivos para a classificação das Tubificidae, quando proveem de localidade, cujo inventário oligoquetológico se ignora: além das 6 espécies determinadas da dita família, restaram, pelo menos 5, não classificáveis, porque se acharam representadas por espécimes imaturos; em duas destas $n \in m$ mesmo o gênero pôde ser reconhecido.

Para facilitar, quanto possivel, o uso de $T u b$ if e $x+u b i f$ e $x$ em trabalhos de caracter geral, descrevemos aquí o material paulista pormenorizadamente, embora seja tão típico em todos os respeitos que, sistematicamente, não haveria necessidade de nova diagnose. 


\section{Tubifex (Tubifex) tubifex (O. F. Müller 1774)}

(Fig. 24, 27-29)

Tubifex rivulorum Beddard 1895, p. 244

Tubifex tubifex Michaelsen 1900, p. 48

Tubifex rivulorum Smith 1900, p. 442, 444

Tubifex tubifex Ditlevsen 1904, p. 41I, 422, 473, 475 t. 16 f. 6-7, t. 18 f. 9

Tubifex (Tubifex) tubifex Michaelsen 1909, p. 37 f. 73

Tubifex (Tubifex) tubifex Pointner 1911, p. 637 etc., 666 f. I-III t. 29 f. 31

Tubifex (Tubifex) tubifex Stephenson 1923, p. 106

Tubifex (Tubifex) tubifex Cernosvitov 1928, p. 5 t. 1 f. 2

Tubifex tubifex Ude 1929, p. 85 f. 81, 99-104

Tubifiex tubifex Altman 1936, p. 15

Tubifex rivulorum Wesenberg-Lund 1937, p. $342-345$ f. $402,4 / 2-414$ t. i0 f. 2

Os vermes das populações ałuais teem $2-4 \mathrm{~cm}$. de comprimento e são desde a côr rósea até a amarelada. Espécimes europeus, cujo comprimento foi indicado por Michaelsen (1900, p. 49) com $3-4 \mathrm{~cm}$., podem, segundo Ude (1929, p. 85), variar de $2,5-8,5 \mathrm{~cm}$. A transparência dos exemplares aquí em mãos possibilita distinguir o sângue vermelho e o revestimento do intestino formado pelas células cloragógenas cinzento-amarelas, presentes do 6. ${ }^{\circ}$ segmento para trás. O diâmetro dos vermes é de 500-600 $\mu_{i}$ a largura máxima, sita no ll.' segmento de vermes sexualmente maduros, alcança 800 $\mu$. $\bigcirc$ número dos segmentos, cujo comprimento iguala, aproximadamente, a largurà, oscila, geralmente, entre 55 e 68, indicando Ude (l. c.) 45-100. O prostômio é côniforme, tão largo quão comprido e ligeiramente pigmentado.

O caracter mais saliente da espécie reside nos feixes dorsais de cerdas dos segmentos anteriores (Fig. 28). Compõem-se, mais frequentemente, por 2-4 cerdas capilares, compridas, grossas e rígidas, e por outras tantas cerdas gancheadas, bifurcadas.

As cerdas capilares em numero de I-4 no material atual (no europeu: 3-6). teem de comprimento $200-400 \mu_{i}$ de grossura 2-3 $\mu$. Com aumento forte revelam-se essas cerdas, às vezes, plumosas (Fig. $27 \mathrm{D}$ ), sendo as cérdulas laterais mais compridas que o diâmetro da haste principal da cerda e dispostas em intervalos um pouco maiores que o dito diâmetro. Para trás, diminue o número das cerdas dorsais, que acabam no $17.0^{\circ}-37 .^{\circ}$ segmento completamente. Em vermes clitelados faltám no $11 .^{\circ}$, e, às vezes, tambem no 12. segmento, as cerdas capilares. As cerdas gancheadas bifurcadas (Fig. 27 B, C ), 3-4 nos segmentos anteriores (3-5 no material europeu), 1-3 nos posteriores (1-3 tambêm no material europeu), possuem grosso nódulo 
ectal e diâmetro de 3,5-5 $\mu$ (segmentos anteriores). Especialmente nas cerdas anteriores ocorrem entre os dois ramos da bifurcação alguns (1-3) dentículos, podendo êsses ramos em outros casos ser reunidos por fina palmoura.

As 2-4 cerdas ventrais (Fig. $27 \mathrm{~A}$ ), nos segmentos anteriores de $5 \mu$ de grossura, são semelhantes às bifurcadas dorsais. Apresentam diversidade do comprimento dos ramos, sendo, em cerdas jovens, o distal mais comprido que o proximal, outras vezes, menos comprido, ou ambos de longura igual. Sempre, porém, é o ramo distal mais fino que o proximal. Nos segmentos posteriores é o ramo distal mais curto que o proximal.

Medidas de algumas cerdas de Tubifex tubifex (Müll.) (em micra)

\begin{tabular}{|c|c|c|c|c|c|}
\hline Segmento & II & III & IV & V & VI \\
\hline cerda dorsal capilar .. & 195 & 295 & 350 & 360 & 400 \\
\hline cerda dorsal bifurcada ... & 75 & 88 & 112 & 115 & 117 \\
\hline cerda ventral ............. & 70 & 90 & 117 & 120 & 117 \\
\hline
\end{tabular}

Massas de células cromófilas encontram-se no $4 .^{\circ}$ e $5 .^{\circ}$ segmento. Os nefrídios começam no $6 .^{\circ}$ segmento, e, no mesmo segmento, as células cloragógenas. As comissuras dos segmentos anteriores formam numerosas sinuosidades; do $4 .^{\circ}$ segmento para trás são dispostas segmentarmente. No $8 .^{\circ}$ segmento ocorrem os grossos corações contrácteis, sendo tambêm as comissuras dos segmentos IX e $X$ sinuosas e contrácteis. As comissuras seguintes suprem o saco espermático e o ovisaco. Do $13 .^{\circ}$ segmento para trás permanecem as comissuras, aí ainda onduladas, mas, não contrácteis, no limite interno do tubo músculo-dermático, i. é, a somatopleura, e são situadas no bordo pesterior de cada segmento.

$G$ ô $n$ a d a s (Fig. 29 A, B): O clitelo (k) abrange os segmentos XI e XII. Os testículos $(t)$, pequenos e tubulares, prendem-se ao dissepimento $9 / 10$, os funís masculinos $(\mathrm{m})$, ao septo $10 / 11$. O duto eferente (d) é comprido, mas, estreito, e percorre enoveladamente os segmentos XI-XIV; fornase mais largo no seu percurso de volta para o $11 .^{\circ}$ segmento, onde o póro masculino se abre ventralmente. A dilatação do duto, o chamado átrio (a) começa na altura do dissepimento $11 / 12$. O átrio claviforme tem parede grossa e lume estreito; entalmente é provido de próstata (p) massiça, superficialmente lobulada. A saida do átrio passa à câmara que aloja o penis (b). A câmara é revestida por cutícula chitínica, formada por duplicatura da parede do corpo e pode ser desdobrada de tal modo que o penis se evagina. O próprio órgão copulador é carnoso, não cuticularizado. O saco esper- 
mático (s). não desenvolvido no material presente, estende-se do dissepimento $10 / 11$ para trás.

No $100^{\circ}$ segmento abrem-se, ventro-lateralmente $(n)$, as espermatecas (e). às vezes ausentes (Stephenson 1930, p. 551). Uma das espermatecas pode estender-se para diante, entrando no $9 .^{\circ}$ segmento, a outra, para trás, até ○ $11 .^{\circ}$ ou, mesmo, até $\circ 130^{\circ}$ segmento. Cada espermateca compõe-se de ainpôla e duto. A ampôla, esférica, quando vazia, saculiforme, quando repleta, contem os espermatozêugmas, i. é, reuniões de muitos espermatozóides grudados por massa argamassadora. O espermatozêugma, nematóịde de configuração, tem parte anterior tanceolada, terminação estreitada, afilada. O trecho ectal do duto da espermateca é evaginavel. Os ovários ( $v$ ) brotam no terço ventral do dissepimento $10 / 11$ e teem forma de $S$, abraçando o intestino (i). Os oócitos mais adiantados são situados perto da extremidade livre do ovário. O ovisaco (u) sai do septo $11 / 12$ e pode estender-se até $\circ 200^{\circ}$ segmento. Contem vários ovários parciais (o), quer dizer, oócitos em crescimento, acompanhados por outros, não crescidos, que mais tarde degeneram. No dissepimento $11 / / 2$ encontram-se, ventro-lateralmente, duas fendas, os orifícios femininos (f).

Procedência: I) Córrego num subúrbio periférico ("Jardim Europa") da cidade de São Paulo, encontrado em quantidade medíocre, juntamente com numerosos exemplares das formas parva e divergens de Limnodrilus hoffmeisteri. 2) Em águas pertencentes ao Tieté, cidade de São Paulo (bairro da Lapa), material abundante.

Distribuição geográfica: América do Norte, estados de Illinois, Washington etc.; Europa setentrional, central e meridional, em altifudes até $2.467 \mathrm{~m}$. e nas profundidades dos lagos até $288 \mathrm{~m}$., tambêm na água fracamente salôbra (Finlândia): Palestina (Cernosvitov 1938, p. 536, 543); Turkestão; Indias Orientais Anteriores; Nova Zeelândia (aí por Michaelsen (1900, p. 49, 524) considerada como espécie introduzida).

\section{E. Sôbre o gênero Bothrioneurum}

(Fig. 30-38)

Em somente dois gêneros das Tubificidae, Heterodrilus Pierant. com uma única espécie marinha, e Bothrioneurum Stolc 1886, faltam regularmente espermatecas, cuja ausência em outras espécies. p. e., em $T u b$ if ex tub if ex (Stephenson 1930, p. 551), embora não rara, todavia, constitue exceção. Nas espécies de $B \circ+h r i \circ n$ e u $r$ u m as espermatecas são funcionalmente substituidas por espermatóforos em forma de cápsulas pedunculadas, fixadas externamente à parede do 
parceiro durante a cópula. E verdade que espermatóforos se conhecem tambêm em Tubificidae providas de espermatecas, mas, nêsses casos, trata-se. mais de espermiozêugmas (Ballowitz 1890, p. 383-386; "sperm-ropes" E. R. Lankester 1871, p. 181) reunidos por secreção, não de espermatóforos verdadeiros. Nas Criodrilinae, Glossoscolecidae aquáticas sem espermatecas e com espe matóforos, a falta de espermatecas foi julgada diferentemente pelas autoridades competentes, vendo Michaelsen (1918, p. 32) nisso um caracter primitivo, Stephenson (1930, p. 888, 889), não. Em B othri on e u $r$ u $\mathrm{m}$ reunem-se à falta de espermatecas outras particularidades que parecem primitivas, a saber: 1) ocorrência de architomia (v. Wagner 1890, p. 392), i. é, divisão sem preparação duma zona especial do corpo, em dois ou mais iridivíduos que regeneram, depois da separação, as partes airida defeituosas; 2) irregularidade da posição das gônadas (Stephenson $1923 \mathrm{p}$. 102): muito pronunciada na espécie aqui apresentada como nova; 3) ocor:ência de músculos das cerdas (não de cerdas) no $1 .^{\circ}$ segmento (Beddard 190I, p. 83); 4) distribuição descontínua: America do Sul (3 esp.). Africa Central (l esp.), Indias Orientais e Pênínsula Malaya (l esp.) e Europa Central, a saber, Bohêmia e Morávia (I espécie).

O parátrio (Fig. 33, p), um grande saco oviforme, anexo ao duto masculino, representa, possivelmente (Beddard 1895 p. 137), o órgão secretor do casulo dos espermatóforos. A covinha sensorial no prostômio completa a combinação dos caracteres peculiares ao gênero $B$ oth $r i$ o n u r u m ; capilares no integumento não ocorrem em todas as espécies.

\section{Bothrioneurum pyrrhum, spec. nov.}

(Fig. 30-34)

De côr ígnea ou de tijolo, localizando-se essa côr não somente nos vasos cutâneos, mas, tambêm em manchas da parede do intestino nos segmentos 9-22. O comprimento dos vermes viventes é de 2-3 cm.i o diâmetro, de 400$500 \mu$. O corpo compõe-se de 50-70 segmentos, havendo, além disso, uma zona de acréscimo pre-anal, sem diferenciação definitiva dos segmentos. O prostĉmio bulbiforme é mais comprido que largo, na base, havendo na linha mediana dorsal uma covinha sensorial. Os segmentos são de comprimento e diâmetro aproximadamente iguais. Papilas sensoriais cutâneas faltam.

As cerdas, agulhas de "crochet" bífidas, iguais nos feixes dorsais e ventrais (Fig. $30 \mathrm{~A}, \mathrm{~B}$ ), formam feixes de $2-5$ nos segmentos pre-clitelares; atrás do clitelo ocorrem $2-3 ;$ do $19 .^{\circ}$ segmento para trás, $2 ;$ do $25 .^{\circ}$ segmento para trás, I. Em indivíduos sexualmente maduros faltam as cerdas dorsais 
do 9. ${ }^{\circ}$ segmento, e as ventrais são transformadas em cerdas genitais (peniais), das quais existem 4-7 por feixe (Fig. $30 \mathrm{C}$ ). O comprimento das cerdas varia muito, podendo, tanto as anteriores quanto as posteriores, ser mais compridas ou mais fracas; foram, p. e., num indivíduo, as anteriores $60-80 \mu$ de comprido, as do $200^{\circ}$ segmento, $100 \mu$; em outro indivíduo, 70 $\mu$ e $52 \mu$, respetivamente. Nos segmentos $2-6$ é o ramo distal mais comprido e mais forte, nos segmentos post-clitelares é o ramo proximal mais grosso, sendo o comprimento dos dois ramos aí igual, ou o proximal é mais longo. As cerdas peniais ostentam terminação grossa e encurvada; mais abaixo do gancho terminal há uma (Fig. $30 \mathrm{C}$ ) ou 2-3 pontas finas e, na face lateral do gancho, algumas áreas de chitina atenuada.

A faringe é muito curta, não se extendendo além do $3 .^{\circ}$ segmento, e provida dum pacote de células glandulares aposto a ela. O clitelo (Fig. 33 , c). situado no $90^{\circ}$ e $10 .^{\circ}$ segmento, é ventralmente algo mais largo que dorsalmente, onde não ocupa na totalidade os dois segmentos mencionados. Comissuras pulsáteis (corações), de calibre mais grosso que as restantes, ocorrem no $6 .^{\circ}$ e 7 . segmento, ou, em animais estéreis, no $8 .^{\circ}$ e $9 .^{\circ}$. Tais indivíduos possuem os primeiros nefrídios, revestidos de células vesiculares, no 9..$^{\circ}$ segmento; animais maduros, somente no $10^{\circ}$ ou $11 .^{\circ}$. Nos nefrídios posterıores faltam as ditas células. As células cloragógenas aparecem do 5. ${ }^{\circ}$ segmento para trás, são de côr cinzenta-acastanhada. Histologicamente diferentes das células cloragógenas, mas, de aparência semelhante nos vermes viventes, são os grandes celomócitos (Fig. 3। B,a).

A parede do corpo, no verme vivo, com $30-40 \mu$ de grossura, é irrigada, do $8 .^{\circ}$ ou $90^{\circ}$ segmento para trás, por vasos sitos intermuscularmente (Fig. 3। $A, B$ ), e oriundos do vaso dorsal. Este último acompanha o intestino no lado esquerdo.

Procedência: 1) Tanque no terrêno da Secção de Ciências Naturais da Faculdade do Filosofia, Ciências e Letras da Universidade de São Paulo. 2) Córrego num bairro periférico ("Jardim Europa") da cidade de São Paulo. 3) Em águas pertencentes ao Tieté, cidade de São Paulo (bairro da Lapa).

\section{As gônadas}

(Fig. 32-33)

Em várias centenas de exemplares foram encontrados, no total, 10 espécimes maduros, cujas gônadas ocuparam os segmentos VIII e IX contrastando tal posição com a normalmente exibida pelas Tubificidae.

As gônadas de dois indivíduos foram duplicadas. O primeiro espécime possuiu ovários bilaterais no $8 .^{\circ}$ e $9 .^{\circ}$ segmento e grupos livres de gonócitos 
masculinos em formação no $7 .^{\circ}$ e $8 .^{\circ}$ segmento. O segundo exemplar anômalo mostrou, além dos primórdios saculiformes dos testículos e ovários bilaterais no $8 .^{\circ}$ e 9." segmento, respetivamente, um saquinho unilateral no $7 .^{\circ}$ segmento, parecido com um testículo jovem.

Regularmente ocorrem os testículos (Fig. $32-33$, t) no $8 .^{\circ}$ segmento, onde se originam quasi por baixo da cadeia nervosa. Daí estendem-se, nos dois lados, racimosamente para cima até a zona em que os grupos dos espermatócitos (s) se soltam, enchendo $\circ 8^{\circ}$ segmento e o saco espermático (Fig. 32, n), alongado até $\circ 16 .^{\circ}$ segmento. Os orifícios dos dutos masculinos são funís largos e profundos (Fig. 32, 33, m), sitos no soalho do $8 .^{\circ}$ segmento. Os dutos (d) são finos e enroscados; cada um dêles entra, imediatamente atrás do seu funíl, com várias alças numa grande massa glandular $(r)$, alargando-se, nêsse percurso, sucessivamente o calibre do duto. Ao sair da aglomeração de glândulas e atravessar o septo 8/9, ○ duto apresenta o seu diâmetro máximo. No 9.० segmento atenua-se novamente e torce-se mais do que foi desenhado. O parátrio $(p)$ constitue um divertículo oval e unilateral do duto eferente. O parátrio lembra uma seringa, de lume estreito, provida de musculatura ao redor da ampôla e, na calota ental, dum tufo de células de caracter glândular. Dois outros pacotes de glândulas diferentes (g) apõem-se ainda ao duto masculino no trecho post-paratrial. O póro masculino impar (Fig. 32,33, a) encontra-se debaixo da cadeia nervosa, na linha mediana da face ventral do $9 .^{\circ}$ segmento. Na bolsa formada pela reunião dos dois dutos eferentes entram os dois feixes de cerdas peniais (e). vindos obliquamente de trás. Fortes músculos, originados na parede dorsal do corpo no $9 .^{\circ}$ segmento, inserem-se na região do póno masculino.

Os ovários (Fig. 32, 33, of fixam-se por baixo da cadeia nervosa, imediatamente atrás do dissepimento 8/9. São racemosos e conteem, além das oogônias, em parte em divisão, ca. de 20-30 oócitos, portanto, pouco numerosos em comparação com os ovários de Limnodrilus. Entre os oócitos em crescimento, providos de nucléolo enorme, notam-se pequenas células foliculares. Oócitos solitários, soltos do ovário (Fig. 33, y), ainda com ooplasma basicromático, flutuam no celoma do $9 .^{\circ}$ segmento, retingindo-se oxicromaticamente o citosoma dos oócitos somente no ovisaco. O último (Fig. 32, i) estende-se do septo $9 / 10$ até o $17^{\circ}$ segmento. Os capilares que suprem a parede do ovisaco são tão finos quão os parietais (Fig. $3 \mid A, B$ ); subdividem-se tão multiplamente que cada oócito dispõe, para o seu crescimento, de uma ou várias alças capilares. Os funís femininos (Fig. 32, 33, f) são situados lateral e posteriormente no 9.0 segmento. Em relação aos gonodutos femininos de outros Limicola, são os da espécie atual bem desen- 
volvidos, e mesmo providos de curtos cílios. Segundo Mehra (1924, p. 149) não ocorrem cílios nos funís femininos das Tubificidae.

No início do $8 .^{\circ}$ segmento salienta-se botão epidérmico impar, mediano (Fig. 32, 33, b), presente apenas em indivíduos sexualmente maduros e. por isso, evidentemente pertencente ao sistema reprodutivo. Topograficamente lembra as espermatecas, ausentes no gênero B othri.o ne u rum que são invaginações pares da epiderme. $O$ botão serve, possivelmente, como base para a fixação dos espermatóforos, mas, nada conseguimos observar a respeito.

\section{Distinção da nova espécie das outras do gênero}

Das quatro espécies de Bothrioneurum, descritas, segundo Cernosvitov (1939, p. 96), até agora, conhecemos apenas as três seguintes: B. vejdovskyanum Stolc 1886, encontrado na Bohêmia e Morávia; B. a merica num Beddard 1894, da Argentina, do Paraguay e do Lago Titicaca; e B. iris Beddard 1901 do Lago Titicaca, de São Paulo (veja p. 205) e das Indias Anteriores e Posteriores. A espécie central-africana, mencionada por Cernosvitov (I. c.) sem indicação bibliográfica, ainda não foi (juiho de 1942) relatada nos órgãos: de referatas ao nosso alcance ("Zoological Record" "Biological Abstracts" "Zoologischer Bericht"), todos retardados pelos acontecimentos políticos. Não obstante, podemos publicar B. pyrrhum como espécie, por certo, nova, visto que Cernosvitov teria mencionado a posição excepcional das gônadas, se tal ocorresse na espécie africana. Em B. a mericanum e B. iris faltam cerdas peniais, sendo, além disso, os póros masculinos pares em B. americanum. B. vei dovskyanum carateriza-se por papilas sensoriais cutâneas e por cerdas peniais providas de dois meio-aneis denteados, além da posição das gônadas no 10.' e 11.0 segmento. Visto constituir o gênero Bothrioneurum unidade taxonômica uniforme, não hesitamos em incluir nêle B. pyrrhum, apesar da posição estranha das gônadas. Essa localização, é verdade, encontra o único paralelo dentro da família das Tubificidae no gênero Aulodrilus de maneira que a criação dum novo gênero talvez tivesse sido indicada, em analogia aos gêneros $\mathrm{Pr}$ istina e $\mathrm{Naidium}$, cujas espécies possuem as gônadas regularmente dois segmentos mais para trás que as outras Naididae. Cremos, porém, que deveria ser esperada a verificação de espécies ulteriores com gônadas normalmente situadas no $8 .^{\circ} \mathrm{e}$ 9. segmento e sinais restantes de Bothrioneurum para proceder à separação genérica. A frequência de anormalidades na posição dos órgãos reprodutivos em B. iris (Cernosvitov 1939, p. 99) recomenda, igualmente, atitude expectante na questão discutida. 


\section{Observações biológicas}

A capacidade regenerativa de B. pyrrhum é muito pronunciada, dando-se $\circ$ mesmo em $B$ vejdovskyanum e possivelmente, em B. iris, não, porém, em B. a meric anum. Architomia foi, segundo Cernosvitov (1. c., p. 99), observada por Hrabe como sendo o método reprodutivo principal em B. vejdovskyanum. Em B. pyrrhum ocorrem frequentemente vermes com oito segmentos anteriores regenerados ou com regeneração de numerosos segmentos posteriores. Muito raros, porém, são os indivíduos com órgãos sexuais. Tais observações fazem presumir a existência de divisão do tipo architômico tambêm na espécie presente. Segundo Cernosvitov (I. c.), não existe estação determinada de maturação em B. americanum tendo o dito autor encontrado vermes com órgãos reprodutivos no verão, no outono e no inverno. O único casulo (Fig. 34), notado por nós e atribuido a B. pyrrhum foi achado em 19.IX, i. é, no início da primavera. Essse casulo, provido de vários envólucros, medía $600 \mu$ de comprimento, $280 \mu$ de diâmetro e continha um único ovo, com $300 \mu$ de longura e $240 \mu$ de largo. O material mais abundante verificámos de outubro a dezembro, os poucos exemplares com órgãos genitais, em novembro e dezembro. Os vermes engolem detrito, empurrando-se, com preferência, para dentro das camadas de folhas podres em decomposição.

\section{Bothrioneurum iris Bedd.}

(Fig. 35-38)

Bothrioneuron iris Beddard 1901, p. 81-87 f. 8-10.

Bothrioneurum iris Stephenson 1923, p. 102 f. 40

Bothrioneurum iris Cernosvitov 1939, p. 100 (literatura) f. 63-67

O material presente abrange três exemplares, 2 maduros e 1 imaturo. Teem de diâmetro ca. de $400 \mu$ e de comprimento, 8-15 mm., alcançando, segundo Stephenson, espécimes índicos, no máximo, $25 \mathrm{~mm}$. O número dos segmentos é de 38-57, no material atual; a literatura indica até 64 segmentos. Os vermes são sanguíneos claros. O prostômio pontudo, côniforme, ultrapassa em comprimento a largura da base. A covinha sensorial, genericamente característica, é situada, nos vermes aquí em mãos, no centro da face dorsal do prostômio, mas, como informa Beddard, pode ocorrer tambêm lateralmente, com mais frequência, no lado esquerdo, ou até ventro-medialmente. 
As cerdas (Fig. 35) são, nos feixes dorsais e ventrais, agulhas de "crochet" bifurcadas, sendo as dorsais, nos segmentos anteriores, um pouco mais compridas. Um feixe abrange, no nosso material, 2-5 cerdas, indicando Beddard 2-4, Stephenson, 3-6. Nos segmentos anteriores é o ramo distal da bifurcação terminal mais comprido que o proximal $e$, no $2 .^{\circ}$ segmento, é tambêm mais grosso (Fig. 35 A). Mais para trás, torna-se o ramo distal mais fino. Nos segmentos XII-XIII são os dois ramos de longura igual, compondo-se os feixes seguintes (Fig. $35 \mathrm{C}$ ) de 2-3 cerdas somente, cujo ramo distal é mais fino e mais curto que o proximal. A variação das bifurcações nas cerdas reunidas num feixe vê-se na Figura $35 \mathrm{~B}$. No segmento do póro masculino faltam as cerdas ventrais. Os folículos das cerdas são acompanhados por grandes glândulas piriformes e paucicelulares (Fig. 37, r). Beddard (1901, p. 83) encontrou no $1 .{ }^{\circ}$ segmento pequeno grupo de músculos que considerou homólogos aos músculos das cerdas.

Medidas das cerdas de alguns segmentos de Bothrioneurum iris Bedd. (em micra).

\begin{tabular}{|c|c|c|}
\hline Segmento & cerda dorsal & cerda ventral \\
\hline$I I \ldots \ldots \ldots \ldots$ & 68 & 60 \\
\hline$I I I \ldots \ldots$ & 70 & 67 \\
\hline$I V \ldots \ldots \ldots \ldots$ & 82 & 78 \\
\hline$V \ldots \ldots \ldots \ldots$ & 70 & 68 \\
\hline região posterior .... $\ldots$ & 60 & 63 \\
\hline
\end{tabular}

As comissuras dos segmentos VII-X pulsam; os exemplares com órgãos reprodutivos teem, nos segmentos VII e VIII, corações largos. Na região posterior do corpo existe o plexo circulatório intestinal, cheio de sângue, assumindo, devido a êste, ○ trato digestivo feição estriada. Além disso, encontram-se as comissuras ordinárias. Beddard e Stephenson negam a ocorrência de vasos cutâneos, o que podemos confirmar. Cernosvitov opõe-se aos autores precedentes e fala em "well-developed blood plexus" e isso, como se segue do conjunto, no integumento.

Os nefrídios, não revestidos por células vesiculares, começam no $8 .^{\circ} \mathrm{seg}-$ mento. Os vermes presentes mostram celomócitos volumosos (Fig. 37, z) e numerosos na cavidade do corpo. Células cromófilas (Fig. 38, c) ocorrem nos segmentos IV-VI. As células cloragógenas (Fig. 38, k) começam no 5. ${ }^{\circ}$ segmento.

A posição das gônadas (Fig. 36) varia: no material aqui em mãos, pertencem os testículos ( $t$ ) ao 10. segmento (nos espécimes de Beddard, ao $\left.11 .^{\circ}\right)$; os ovários (v), ao 11.0 (12.' Beddard). O clitelo (c) abrange os seg- 
mentos XI e XII (XII e XIII, Beddard); o póro masculino (a) é situado no $11 .^{\circ}$ segmento (no 12. ${ }^{\circ}$ Beddard). O ovisaco estende-se até $\circ$ 14. segmento. A posıção observada no sistema reprodutivo do material atual ocorre tambêm em vermes pesquisados por Stephenson.

Os testículos e os ovários (Fig. $37, t, v$ ) brotam nos segmentos aludidos nas imediações da cadeia nervosa, de maneira que as gônadas do lado esquerdo quasi confinam, na sua origem, com as correspondentes do lado direito. Grupos de espermatogônias soltam-se do testículo e entram no saco espermático (Fig. 36, 37, s), que se estende do dissepimento $11 / 12$ até o $13 .^{\circ}$ segmento, aproximadamente. No saco processa-se o crescimento, passando aí as espermátides tambêm pela fase histogenética. Como espermatozóides, os gonócitos masculinos são conduzidos para fora pelo funíl masculino $(\mathrm{m})$, fortemente ciliado e sito no dissepimento $10 / 11$, e entram no duto eferente (d). O primeiro trecho dêste é enroscado, de calibre pequeno, delimitado por células menos altas que as do funíl e revestido por células peritoneais em camada coerente. O fim do $10^{\circ}$ trecho do duto eferente é marcado por dilatação que caracteriza o início do 2. trecho, histologicamente igual à porção anterior, porém, mais largo. A terceira parte do duto eferente difere histologicamente das duas precedentes, sendo, além disso, mais larga que o segundo trecho. As células da parede dessa 3. secção do duto eferente salientam-se para dentro, formando pequenas dobras ou vilosidades; o revestimento peritoneal é mais escasso que nos dois trechos anteriores.

Como foi dito por Cernosvitov (1939, p. 99), é dificil homologar os componentes do aparelho eferente masculino das espécies de Bothrioneu rum com os das outras Tubificidae. Apesar de ser tubuliforme e enroscada, a 3.a parte do duto eferente, caracterizada pelas vilosidades, poderia ser chamada de átrio (Fig. 36, 37. x). A parede do átrio é provida de musculatura. O parátrio (p) é semelhante ao de B pyrrhum (Fig. 32-33, p). mas, em B. iris, um pouco menos volumoso. Por outro lado, é o átrio de B. pyrrhum (Fig. 33, x) apenas representado pelo curto trecho largo do duto eferente, um pouco antes e atrás do parátrio. Cernosvitov (1939, p. 99) propôs o nome de parapróstata para as células glandulares na calota ental do parátrio. As glândulas post-paratriais (Fig. 32-33, 36-37, g) poderiam então talvez ser chamadas de próstatas. Em B. pyrrhum, porém, tal denominação seria inadequada à glândula ectal dos dois grupos post-paratriais, pois essa não pertence mais ao átrio, como a próstata das outras Tubificidae. Sem pesquisas ontogenéticas e funcionais, nem as homologias, nem as analogias entre os vários gêneros podem ser estabelecidas. Já dentro do mesmo gênero existem diferenças, eventual- 
mente de importância fisiológica. Tal se vê pela comparação do $4 .^{\circ}$ trecho do duto eferente em B. pyrrhum e B. iris. Esse tubo, que liga o átrio com a câmara copuladora, é comprido na primeira e curto na segunda espécie. Tanto na primeira como na segunda, reunem-se êsses dois dutos ventralmente à cadeia nervosa. Nos espécimes de B. iris, aqui em mãos, desembocam no terço posterior do $11 .^{\circ}$ segmento com póro estrelário, impar e central (Fig. 36, 37. a). Em B. iris, desprovido de cerdas peniais, quasi não se pode falar em câmara copuladora.

Do ovário soltam-se os ovócitos em crescimento que entram (Fig. 36, 37. o) no ovisaco. Os funís femininos (f), sitos no septo $11 / 12$, são providos de cílios fortes, bem maiores que em B. pyrrhum. As duas aiderturas femininas encontram-se em covinhas laterais da face ventral, imediatamente atrás do dissepimento $11 / 12$. O botão epidérmico, desenvolvido no incício do $8 .^{\circ}$ segmento dos vermes maduros de B. pyrrhum, falta em B. iris. Os espermatóforos, ausentes no nosso material, são aproximadamente fusiformes e fixados, por meio de pedúnculo, em número de 1-5, à face ventral dos segmentos clitelados.

Procedência: Charco nos arredores de São Paulo, entre folhas caidas.

Distribuição geográfica: Lago Titicaca (perto da Isla Titicaca, Bolívia) e arredores (território peruâno): Indias Orientais Anteriores, em altitudes até 2500 m.i Pênínsula Malaya.

\section{$A$ região anterior de Bothrioneurum iris}

(Fig. 38)

O prostômio e os três segmentos anteriores carecem de septos separadores. Não obstante, demarcam-se os compartimentos sucessivos sem dificuldade. A covinha sensorial (s) e a posição pre-bucal distinguem $\circ$ prostômic ou lóbulo cefálico, cujo limite posterior coincide $\mathrm{ccm}$ os músculos dorso-ventrais situados antes do cérebro. A boca (b) e o gânglio supra-faringeo ou cérebro (a) pertencem ao primeiro segmento. $O$ segundo segmento caracteriza-se pelos primeiros feixes de cerdas, visíveis, em virtude da sua posição lateral, somente nos cortes sagitais da série, cujo corte medíano foi desenhado. O terceiro segmento contem, além dos segundos pares de feixes de cerdas, a faringe, e, para trás, é delimitado do quarto segmento pelo primeiro septo completo do verme.

A covinha prostomial mostra compridos pêlos sensoriais e tem ligação com o gânglio supra-faringeo. A cutícula do prostômio, aí desenvolvida do mesmo modo que no corpo restante, é interrompida na covinha sensorial. 
Um dos nervos saidos do cérebro, que suprem os botões sensitivos da epiderme do prostômio, vê-se na Fig. 38, que, aliás, é apenas topográfica e não visa pormenores histológicos. Da faringe são notaveis os pacotes de células glandulares (g) no teto dêsse órgão. As células da própria parede faringea são, em parte, destituidas de núcleos. Depreende-se disso que os citosomas, sem núcleos, representam apenas a parte periférica das células glandulares. Existe, sem dúvida, musculatura esplâncnica entre a parte ciliada, interna e a parte glandular, externa da faringe. Apesar disso, leva a relação numérica entre núcleos e citosomas à opinião de se tratar, na faringe, de epitélio, em parte, aprofundado e diferenciado em zona interna, ciliada e externa, glandular. Em certas Naididae iá encontrámos número ainda muito menor de núcleos na zona interna da faringe, de maneira que havemos de voltar ao assunto em questão no estudo da dita família.

As células cromófilas (c), reunidas ao redor de vasos ( $v$ ) ou fixadas aos septos, concordam, nessa localização, com os elementos correspondentes das outras Tubificidae, pesquisadas a respeito (Stephenson 1930, p. 85). Também em Bothrioneurum iris faltam quaisquer comunicações entre as células cromófilas e o lume do intestino.

\section{F. Archigetes sieboldi Leuck., parasita das Tubificidae} (Fig. 39-41)

Os únicos Cestodes, cujo ciclo evolutivo pode realizar-se completamente em Invertebrados, são as três espécies do gênero Archigetes Leuckart 1878. Vivem no celoma de certos Oligochaeta límnicos da família Tubificidae, principalmente, em Limnodrilus hoffmeisteri, mas, tambêm, em L. claparèdeanus, L. willeyi, Tubifex tubifex e T h'attai Até agora conheceram-se da Europa centrai, do Japão (Motomura 1929) e da América do Norte (Hunter 1930, p. 144).

Graças à minha Esposa, Exma. Sra. D. EVELINE DU BOIS-REYMOND MARCUS, conseguimos verificar essas raras solitárias em $\mathrm{Limnodrilus}$ hoffmeisteri forma parva Southern e em L. udekemianus Claparède de São Paulo (*), de várias localidades.

Os parasitas, jovens e maduros, foram encontrados, em número de 1 a 4, no saco espermático, no ovisaco e na cavidade do corpo dos hospedadores mencionados (Fig. 39).

$(*)$ Os primeiros exemplares infestados com solitárias devemos ao Colega Dr. Giórgio Schreiber, que os obteve do Sr. João de Paiva Carvalho do Departamento da Produção Animal. A ambos agradeço o material que se revelou tão interessante. 
O gênero Archigetes foi, há pouco, estudado monograficamente por L. W. Wisniewski (1930), da escola do conhecido helmintólogo C. Janicki. O nome específico, adotado por Wesenberg-Lund (1937, p. 191) e aquî, não é usado por Mrazek (1908, p. 719 e seg.), Fuhrmann (1931, p. 327) e a maioria dos autores. Ao escreverem Archigetes appendi culatus (Ratzel), concorda tal procedimento com a opinião de Leuckart (1878, p. 597, 60I), que teve o seu material por idêntico à espécie de Ratzel (1868a, p. 138 t. 4 f. 1-4). Apenas propôs nova denominação específica, porque considerou $o$ apêndice como sinal genêrico e, por isso, impróprio para caracterizar a espécie. Visto que a regra da prioridade do primeiro nome veda a alteração efetuada por Leuckart, entende-se o uso comum do nome appendiculatus. Mas, dois caracteres, a forma da região cefálica (scolex) e, especialmente, o sistema excretor com um tronco principal terminal na espécie de Ratzel, não concordam com as partes correspondentes da de Leuckart. Por isso, chamamos, seguindo a Nybelin (1922, p. 134, 137-141), Hunter (1930, p. 110) e Wisniewski (1930, p. 2-3) o nosso material de Archigetes sieboldi Leuck.

Leuckart, Hunter (1930, p. 146) e Wisniewski tentaram em vão infestar peixes com fases jovens e com vermes cheios de ovos maduros, embora constituam Limnodrilus e Tubifex comida regular dos peixes bentófagos, e sejam, como tal, vendidos em certos mercados (Stephenson 1930, p. 657). Wisniewski verificou realizar-se o ciclo normal dos seus espécimes do modo seguinte: O parasita maduro faz inchar o corpo do Oligoqueto consideravelmente. A intumescência ocasiona, às vezes, lesão do tubo músculo-dermático por fatores mecânicos externos, ou o próprio parasita faz arrebentar a parede do corpo do hospedador. As solitárias libertadas morrem nágua, mas, os ovos sobrevivem à decomposição do corpo materno, espathando-se na vasa habitada pelos ditos Oligoquetos. Com esta são engulidos pelas Tubificidae, em cujo trato intestinal as larvas saem dos ovos operculados. Passam pela parede do intestino e entram na cavidade do corpo. Localizam-se, no nosso material, como no de Mrazek (1908; o trabatho anterior checo, do mesmo autor, de 1897. conhecemos apenas pela referata de v. Linstow, no Archiv für Naturgeschichte, Jahrg. 1896, vol. 2 fasc. 3, p. 34), com preferência nos segmentos genitais e aí permanecem até alcançarem a maturidade.

Os autores concordam a respeito da raridade de Archigetes. Nos mais de 5 mil vermes, pertencentes aos gêneros Limnodrilus e Tubifex e examinados por Hunter (1930, p. 145), menos de $1 \%$ conteve parasitas; nos mais de 15.000, pesquisados por Wisniewski (1930, p. 7), 2,26\% se acharam parasitados. No nosso material foi a porcentagem dos vermes 
parasitados muito maior, mas, como os vermes, quando chegaram às nossas mãos, já tinham sido mantidos no cativeiro, portanto, em condições especialmente favoraveis à infecção mútua, os nossos dados não são demonstrativos.

Notámos nas Tubificidae parasitadas comprimento inferior ao normal e castração parcial. Os próprios órgãos reprodutivos do hospedador não são alterados, mas os sacos (Fig. 39, s, o), em que os gonócitos dos Oligoquetos crescem e amadurecem, são de tal modo preenchidos pelos parasites que se torna mecânica e, ao que parece, tambêm fisiologicamente, impossivel o desenvolvimento normal dos espermatócitos e oócitos. Não vimos gonócitos inaduros de hospedadores parasitados na região genital. Com isso não queremos excluir a possibilidade de tal desenvolvimento nas Tubificidae infestadas, nomeadamente se o parasita, como às vezes acontece, se localizar fora da zona dos órgãos reprodutivos.

Ainda que não iguale a capacidade regeneradora das Tubificidae à das famílias vizinhas dos Oligochaeta limícolas, a saber, Naididae e Lumbriculidae, a deiscência local da parede do corpo, causada pela saida do parasita, há de ser seguida por cicatrização e reparação dos tecidos atingidos. Desta sorte, escapará o Oligoqueto das consequências extremas da verminose.

Não podemos confirmar que exista outra conexão entre as solitárias e os vasos do hospedador (Wisniewski 1930, p. 19-20) além do contato. Tal estabelece-se, certamente, visto que as solitárias preenchem o saco espermático (Fig. 39, s) ou o ovisaco de tal maneira que os estendem, entrando, destarte, em contato íntimo com os vasos parietais dêsses divertículos. Nas espécies hospedadoras em questão começa o saco espermático no dissepimento 10/11, o ovisaco, no septo 11/12. A impossibilidade de isolar, senão com força, o parasita do hospedador levou Wisniewski à ideia de verdadeira coerência dos tecidos. Mas; a circunstância aludida deve-se à natureza dos sacos; cuja evacuação é realizavel apenas pelo lado da frente. Abrindo o segmento precedente ao do saco infestado, i. é, o $10 .^{\circ}$ ou 11. ${ }^{\circ}$ - parasita pode ser isolado sem delongas. Nêsse processo auxilíam até os músculos do corpo do hospedador, esvasiando, pela contração, o saco. Se, porém, a tentativa da isolação do parasita fôr empreendida nos segmentos posteriores, encerram os músculos do Oligoqueto a solitária de tal modo no respetivo saco que não é possivel libertá-la. Extração forçada, além de despedaçar o parasita, teria de lacerar a parede do saco, e, com isso, rasgar várias alças meândricas das comissuras circulatórias que suprem a dita parede.

Pela forma e pela maturação dos ovos no primeiro hospedador apresenta-se o parasita como larva (procercóide) neotênica, i. é, madura na fase larval. O comprimento do procercóide caudato maduro de Archigetes 
sieboidi varia de 2,2 a $4 \mathrm{~mm}$., a largura, de 0,4 a $0,65 \mathrm{~mm}$. O corpo (Fig. 40) compõe-se por tronco e apêndice caudal. O último atinge quâsi a metade da largura do tronco e contem, terminalmente, 6 ganchinhos (Fig. 40, g), resíduos da fase embrionária. A região anterior ou parte cefálica possue duas concavidades (bótrios) ovais (b), sitas nos lados dorsal e ventral. Quando isolada na lâmina, a solitária serve-se dos bótrios como ventosas, mas, no corpo do hospedador não se fixa por meio dêles em qualquer tecido do Oligoqueto. A plasticidade do corpo, que se estende e se contrai continuamente, altera tambêm a configuração da cabeça $\theta$ dos bótrios (Fig. 4I). Na fase da contração dobra-se a cutícula, formando um sulco, que se desloca, com contração ulterior, para diante. Entre os bótrios encontram-se, no parênquima central, células de caracter glandular, as glândulas frontais. Mais conspícuo é outro complexo de células cervicais (Fig. 40, e).

Visto que o integumento, a musculatura e o parênquima foram descritos pormenorizadamente por Wisniewski, passamos à exposição sumária do sistema reprodutivo, taxonomicamente importante nas particularidades, e, assim, justificatório da nossa determinação específica.

Os testículos (Fig. 40, †) formam, em cada lado, 3-4 ou mais séries longitudinais, pouco regulares, contendo cada série $16-18$ vesículas testiculares, cada uma de ca. de $0,04 \mathrm{~mm}$. de diâmetro. Os testículos são situados medialmente às glândulas vitelógenas (vitelários), na região antero-central do corpo, e começam caudalmente aos vitelários. Êstes, compostos por folículos elípticos ( $v$ ), teem forma de U. O viteloduto (d) origina-se pela reunião de dois dutos laterais e desemboca no oviduto caudalmente à vagina (a). Os canais eferentes masculinos concorrem à formação do canal deferente que se dilata como vesícula seminal (s). O dito canal estreita-se novamente, quando entra na bolsa do cirro (b), dorsalmente situada. $O$ percurso do canal deferente na bolsa é tortuoso, havendo ligeira dilatação do último trecho, o cirro, que atinge o póro genital (p). O próprio póro permanece coberto pela cutícula.

Os dois ovários (o) pertencem à região posterior do tronco e são constituidos por massas de vesículas piriformes. Lateralmente são mais grossos e mais largos que para dentro. No centro do duto transversal, que liga dois ovários, sai, com esfincter nítido (h), o oviduto, que se dirige para trás. Nêle desembocam a vagina (a) e o viteloduto (d), sendo o trecho interno da vagina, o chamado duto seminal, algo mais fino que a parte anterior. Dilatação do trecho externo da vagina, chamado de receptáculo seminal, nem sempre é nítida. Caudalmente à desembocadura do viteloduto continua o oviduto sem glândulas (parte pré-glandular do oótipo), até começar a parte com 
circumvoluções, o oótipo (i), acbmpanhado por glândulas. O oótipo é seguido pelo útero (u), comprido e largo, mesmo na fase desenhada na Figura 40, em que não contem ovos. As alças do útero envolvem a bolsa do cirro $e_{1}$ às vezes, tambêm a vesícula seminal. Quando repleto, dilata o útero toda a metade posterior do tronco, cuja forma então se torna garrafal. Os ovos teem de comprimento 0,06-0,065 mm., de largura 0,035 mm., no material presente; Wisniewski (p. 66) indica longura de 0,045-0,06 e largura de $0,02-0,03 \mathrm{~mm}$.

A comunidade dos orifícios masculino e feminino facilita a auto-fecundação que deve ser a regra na espécie atual, porque o póro genital permanece coberto pela cutícula.

O sistema nervoso, conhecido, até agora, apenas pela reconstrução de cortes, imprópria para verificar as terminações, não foi estudado por nós. Segundo Wisniewski, consiste em dois troncos longitudinais principais e quatro outros, secundários, todos êles ligados por comissuras.

A rede complicada dos canalículos excretórios revela-se, com nitidez invulgar na maioria dos Platyhelminthes, em vermes observados em solução fisiológica diluida $(0,3-0,4 \%)$. A bôa figura publicada por Wisniewski (1,930, t. 4 f. 13) torna supérflua nova ilustração. Ao lado dos cílios dos órgãos terminais, cujas vibrações se vêem com imersão no verme vivente, atuam os músculos do corpo como forças hidromotrizes no escoamento dos excretos.

\section{Discussão}

Como já se depreende do título do seu trabalho, considerou Leuckart (1878, p. 597. 60I etc.) a solitária que descreveu, como larva sexualmente madura na fase de procercóide. Sistematicamente avizinhou o gênero à família Caryophyllaeidae, posição que conservou até hoje, se bem que tenha perdido o gráo de "Archigetes" i. é, avoengo. As Caryophyllaeidae foram aproximadas às Bothriocephalidae (Diphyllobothriidae de hoje) e entraram na ordem dos Pseudophyllidea (Lühe 1910; Nybelin 1922, p. 116). Fuhrmann, que impugna a opinião de qualquer parentesco entre Cestodes e Trematodes (1931, p. 329), coloca no início do sistema das solitárias os Tetraphyllidea (ibid., p. 24I, 406), principalmente, porque habitam os Vertebrados ancestrais, os Selachii, em que Pseudophyllidea não ocorrem. Dentro desta última ordem tem Fuhrmann (1931, p. 329-330) as Caryophyllaeidae por grupo aberrante. Segundo êle, corresponde o corpo das Caryophyllaeidae, monozóico, i. é, provido dum único complexo de órgãos genitais, ao plerocercóide, i. é, à larva no $2 .^{\circ}$ hospedador intermediário dos Pseudophyllidea com ciclo completo. Os vermes caudatos do gênero Archige- 
te s seriam procercóides, i. é, larvas no 1.0 hospedador intermediário (ibid., p. 326, 330), neotênicos; os ecaudatos, dos outros gêneros das Caryophyllaeidae, plerocercóides neotênicos.

Adotamos a opinião de Fuhrmann, que é tambêm a de Mrazek (1916, p. 531-532) e Nybelin (1922, p. 142), embora haja oposição, como quasi sempre na sistemática, de todo subjetiva. Lembramos as Appendiculariae, ora consideradas como larvas neotênicas dos Ascidiacea (Heider 1893, p. 1419-20; e outros autores), ou dos Thaliacea Cyclomyaria (Garstang 1929, p. 93-135), e até chamadas de Larvacea, ora separadas das larvas dos Tunicata e tidas por grupo de caracteres mixtos, primitivos e aberrantes (Ihle 1913, p. 518-522). De maneira análoga opõe-se Woodland (1923, p. 466; 1926) a Nybelin e Fuhrmann, reunindo as Caryophyllaeidae com os Cestodaria, i. é, Amphilinidae e Gyrocotylidae. Cremos, porém, que a íncorporação das Caryophyllaeidae nos Pseudophyllidea, baseada na anatomia de todos os órgãos, terá de alcançar adoção universal.

A precocidade do desenvolvimento do sistema reprodutivo nas Caryophyllaeidae, que já figura nos tratados (Wesenberg-Luna 1937, p. 190) e se repete (Wisniewski 1933, p. 323) na família vizinha das Cyat'.7ocephalidae (por Nybelin reunidas na mesma família), conta com um exemplo dos mais ilustrativos em Glaridac.ris limnodrili (Yamaguti 1934, p. 10-12). Nesta espécie, não se distinguem, morfologicamente, o procercóide e o plerocercóide, o último a fase definitiva, sendo ambos ecaudatos e sexualmente maduros. A ocorrência no celoma de vermes do gênero Limnor drilus e no intestino de peixes (Pseudogobio, Misgurnus) é que permite as designações de procercóide e plerocercóide, respectivamente, aliás, de todo dispensáveis nos livros escolares (*). Em Glaridacris li m nodrili, a fase, segundo o hospedeiro, procercóide apresenta-se, somaticamente, plerocercóide e, generativamente, solitária adulta.

O reino animal oferece várias exceções da regra de coincidir diferenciação somática máxima com maturação das células germinativas. A precocidade da formação dos órgãos reprodutivos deve ser determinada por fatores endógenos, genéticos ou hormonais. Não parece lógico falar Wisniewski (1930, p. 150-15I) da adaptação regressiva em Archigetes,

(*) Da exposição de Mrazek (1916, p. 553), cheia de atualidade, realçamos apenas - seguinte: "Continuamos a usar os termos técnicos, significativos somente à luz do andamento histórico da ciência, e apesar de haver mudado profundamente o sentido dêles, desde que foram criados. O jovem zoólogo, em vez de aprender os processos análogos, recebe, já no início dos seus estudos, informação a respeito dos nomes históricos, impeditivos do entendimento do conjunto. A exposição da metamorfose e dos prociessos complicados dos ciclos evolutivos pode ser feita sem tal bagagem, que apenas sobrecarrega a memória do estudante" 
cujo ciclo evolutivo ficou abreviado por causa da extinção do hospedador final, talvez certo grupo de peixes. Tal "adaptação" deveria ter sido preventiva. Se o hospedador final duma fase larval, destituida de gonócitos, se tivesse tornado sucessivamente mais raro, teria diminuido a próle da solitária. Com a morte do último hospedador principal (final) o parasita tambêm extinguir-se-ia. O desenvolvimento precoce dos órgãos e células sexuais é o acontecimento primário. Muitas espécies das Caryophyllaeidae possuem êsses órgãos, quando entram no peixe. Existe, evidentemente, correlação, possivelmente hormonal, entre a organização adiantada e a maneira da localização das Caryophyllaeidae, que consideramos, na fase final, como plerocercóides. Em oposição aos plerocercóides imaturos dos outros Pseudophyllidea, permanecem as Caryophyllaeidae maduras no intestino do 2 . hospedador, não migrando ao celoma. Seja frisado, de passagem, que o mesmo acontece em outra família dos Pseudophyllidea, a saber, em Euboth rium crassum (Bloch) (Nybelin 1922, p. 163), cujo ciclo é completo e abrange plerocercóide imaturo típico.

Independentemente da adopção ou da rejeição da teoria de Fuhrmann de considerar Archigetes e as outras Caryophyllaeidae como procercóides e plerocercóides, respetivamente, continua Archigetes fase neotênica, não progenética, como Szidat (1937; 1938) diz. Mistura de sinais juvenís (no caso atual, o apêndice caudal) e definitivos (tamanho; órgãos reprodutivos em função) caracteriza o animal neotênico, sendo progenético o organismo somaticamente larval e sexualmente maduro. Como se sabe dos cupíns (Heath 1903, p. 58-59; Holmgren 1906, p. 574, 610 etc.) não há limite rigoroso entre progênese e neotenia.

Já foi previsto por Nybelin (1922, p. 142-143) e Hunter (1930, p. 148) a possibilidade de sobrevivência ocasional de Archigetes em peixes. Eventualmente refere-se a tal fenômeno a nota de Ward (1911), cuja brevidade, porém, não permite reconhecer o parasita. Mais verosimil parece que os 4 vermes encontrados por Szidat (1937) no intestino de Tinca vulgaris pertencem a Archigetes. Distinguem-se de A sieboldi somente pela falta da cauda, mas, o sistema excretor, muito singular em $A$. sieboldi, não pôde ser reconhecido. São um pouco menores os espécimes de Szidat que o tronco de A. sieboldi, mas, todavia, permanecem dentro dos limites da variação. As indicações a respeito do "caracter incompleto, larval, do exemplar mais jovem em comparação com - maior, cujos tecidos se mostram revolvidos e amadurecidos" (Szidat 1937. p. 170), não provam "desenvolvimento no hospedador final" Poderiam tão bem referir-se às fases alcançadas pelo parasita em Limnodrilus e engulidas pela tenca de uma só vez. Essa interpretação é até a mais vero- 
simil, visto que 4 parasitas podem existir no mesmo Oligoqueto. A fixação dos bótrios na mucosa intestinal da tenca considera Szidat como outra prova de que as solitárias se encontravam "no seu hospedador certo em que continuaram o seu desenvolvimento ulterior" Mas, na verdade, não significa escolha biológica, pois que se efetua tambêm, quando os vermes se encontram isolados na lâmina em solução fisiológica. Com toda razão admira-se Szidat de que o parasita, até 1937, não foi visto na tenca. Esse peixe é entre as Cyprinidae da Europa e Sibéria ocidental uma das espécies mais comuns e mais vastamente espalhadas. Szidat explica o fato estranho da raridade evidente de Archigetes na tenca pela suposição que o parasita, com os órgãos reprodutivos já desenvolvidos no Oligoqueto, não demora no hospedador final, do qual é eliminado em breve. Com essa explicação parece inconciliavel o desenvolvimento no "hospedador certo" exposto uma página antes.

Szidat descreve os seus espécimes como $B \mathrm{i} a \mathrm{cetab}$ a l u m sie b o l d i n. sp., considerando-os como fases definitivas de A r c h i g e te s s i e b o l d i Leuck. Se fossem tais, não constituiriam nova espécie. Se um verme pertencente ao gênero Biacetabulum Hunter 1927 (1930, p. 82) fosse a fase ecaudata de outro, até agora conhecido somerte na fase caudata, seria Bi a cetabulum sinônimo de Archigetes, como já foi dito por Fuhrmann (1939, Zool. Ber. v. 46, p. 437) na sua referata do trabalho de Szidat. Por enquanto tal sinonimia ainda não foi provada. O sistema excretor é diferente em A r c h ige te s e B i a cetabulum e a região cefálica de Archige te s distiague-se do scolex bem definido das espécies de $B$ i a c e ta $a b$ u I u m Quanto à região cefálica corresponde o material de Szidata $A r c h i g e$ t e s não às espécies até agora conhecidas de $B i a c$ e $t a b$ u l u m. Por isso, cremos tratar-se realmente de 4 exemplares de Archigetes s i e b o I d i Leuck., cujas caudas se desataram por razões mecânicas. 0 ciclo evolutivo de Archigetes si e b old i não precisa de outro hospedador além dos Oligoquetos, mas, evidentemente a solitária suporta, às vezes, tambem o meio diferente no intestino de peixe.

No seu trabalho de 1938 descreve Szidat uma espécie das Caryophyllaeidae, do intestino de $G \circ b$ i o fJu $v i a+i l i s$ intermediária, nos seus caracteres entre Archigetes e Glaridacris e considerada pelo autor como tipo de novo gênero Brachyurus. Não é identica a Archigetes brachy ur us Mrazek, mas muito menor, como o próprio autor expõe (p. 252). Apesar disso não hesita em colocar A brachyurus como nome de Brachyurus brachyurus no novo gênero, o que parece prematuro. Por enquan- 
to. sabe-se apenas que os ovos de $A \quad b r a c h$ y u $r$ us se tornam maduros no 1." hospedador, $L i m n \circ d r i l u s h$ off $m$ e iste $r i$ O nome genérico B r a ch y u r u s figura no "Nomenclator Zoologicus" de Neave (v. 1, 1939. London) já 7 vezes, de maneira que não pode ser usado mais uma vez para novo gênero das Caryophyllaeidae.

\section{G. Summary}

Michaelsen s compilation of brazilian Oligochaeta (1927) contains no species of Tubificidae. This shows, that this family, comprising about 120 species, has not been looked for, as the family is not missing in the tropics.

The specimens treated here are from São Paulo, the first was also received from Ceará.

To the list of 12 known species of $P$ eloscolex $(p . \mid 56)$ we did not admit $L i m n \circ d r i l u s$ heteroch a e tus Mich., that was erroneously ascribed to P. by A. de Vos (19.36). On the other hand P. $m$ a $r$ i n u s (Ditlevsen) was counted separately, because its setae are different from those of $P . \quad b$ e $n$ e $d e n i$ and it has a penis-sheath.

$P e l o s c o l e x$ evelina e spec. nov. (Fig. I), has cuticular not confluent, and sensory papillae (Fig. 3). The dorsal setal bundles beginning in the 6. segment consist of one smooth hair seta $(\mid 70 \mu)$ and a minute needle $(35-40 \mu$ ) (Fig. $2 \mathrm{~A}$ ). The 2-4 double-pointed crotchets of the ventral bundles are in segments 2 to 5 (Fig. 2 B) smaller than in 6 and the following (Fig. 2 C). The lower (proximal) prong is thicker than the upper (distal) one. The rough surface of the cuticular papillae is due chiefly to ramifications and irregularities of the secretion and not to foreign particles. These papillae have a core of densely concentrated secretion. The sensory papillae are covered with a thin cuticle that has a rodlet border and forms one to three sense-hairs. In the papilla one sees the neurofibrils of the sensory cells.

In regenerated segments the cuticular papillae are smaller than in the normal ones, and in the latter the size of the papillae varies in the same bodyregion. That seems to indicate shedding of old papillae and substitution by new cnes. Epithelial sense-organs likening the sensory papillae of $\mathrm{PelO}$ scolex evelinae have been described as sensory papillae in Sla $\checkmark$ in a a p p n d i c u l a $t$ a by Vejdovsky and as sense-organs in A u I o phorus vagus by Brode. In both these species the external case of foreign particles makes orientation about qualities of the habitat difficult, as it is likewise made by the cuticular papillae in $\mathrm{P}$ e I o s c o I e $\mathrm{x}$ e $v$ e I i n a e 
Exposed to light P. e. forms homotypic synaporia (Deegener), that is, it shows aggregative reactions.

As in the present material Lim nodrilus parvus Southern was always recognizable by its small size and the longer proximal prongs of the anterior setae (Fig. 4A), it seems advisable to maintain this species as forma to $L$. h of $\mathrm{m}$ e is te $\mathrm{ri}$ and not to reject it completely as does Cernosvitov (1939).

In Limnodrilus hoffmeisteri forma divergens f. $n_{\text {.r }}$ the anterior bundles have 7 to 11 setae with the distal prong longer than the proximal one (Fig. 6 B). Backwards the number of setae per bundle decreases and the proximal prong is longer. The length of the worms is up to $70 \mathrm{~mm}$, the diameter $600 \mu_{i}$ they have 210 segments. The length, number of segments and double anterior sperm sac place forma $d i v e r$ ge $n s$ nearer to $L$. socialis than to $L$. $h$ of $f m$ e isteri. But $s \circ \mathrm{cialis}$ and $h$ of $f \mathrm{meisteri}$ were united by Michaelsen 1935 and Cernosvitov 1939. The ratio of width to length of the penissheath varies from $1: 7,2$ to $1: 10,6$ in $f$. $d i v e r g$ e $n s$ (Fig. 9); the average of 10 worms is $1: 8,3$, that lies under the minimum given by Cer. nosvitov (1939, p. 105), and none of our specimens reaches the maximum of $h$ of $f m e i s t e r i \quad A$ table of length and width of the penis-sheath of 10 animals see p. 172.

The occurrence of $L i m n \circ d r i l u s$ udekemianus fFig $10)$ in São Paulo was zoogeographically unexpected, but the thick skin, the network of cutaneous blood-vessels (Fig. 16), the length of the segments anc the dark colour characterize this species in the group of $\mathrm{Lim} \mathrm{nod} \mathrm{rilu}$ with short penis-sheath. In our material the width-length ratio is $1: 2$ ! to $I: 4$. The nearest related species is $L$. $w i \mid l$ e y $i$ Nomura.

A sub-intestinal vessel is wanting in the present species of $L i m n \circ$ $d r i$ I u s (Fig. 12-13). One pair of hearts lies in. the 8. segment (Fig. ? 8, 11); and also the commissures of the 9. and 10. segment are contractil (Fig. 17). In f. divergens the dorsal vessel leaves the dorsal side $i$ the 9. segment and runs first ventro-laterally and later on the left side of th gut. It communicates with the intestinal blood-plexus. The supra-intestin vessel (Fig. 11, 12, s) arises from the dorsal vessel in the 8. segment. Whi re it passes through the anterior septa it is occluded by a muscular apparati similar to that described by v. Haffner (1927. p. 22). The commissures 1 the segments 4-7 (Fig. 11, 12, ol part from the supra-intestinal vessel, ar from segment 9 backwards, from the dorsal vessel. The anterior comm sures are coelomatic, as they run within the somatopleure. They are st pended by mesenterial folds. The hearts of $L$. h of $f m$ e is te $r i$ 
$p a r v a$ and $f . d i v e r g$ e $n s$ are dorso-ventral hearts (Stephenson 1930, p. 149), not intestinal ones. In sexually mature specimens the commissures of the segments 9-11 are very well developed and supply the genital organs. The bifurcation of the dorsal vessel in the prostomium and the branching of the supra-intestinal vessel in segments 2 and 3 is shown in Fig. 11. The 4. segment is the first with typical lateral commissures. The cutaneous vessels do not end blindly. They are the commissures of the posterior segments (in L. h. f. d i verge $n \mathrm{~s}$ beginning in the 86., in L. u d e $\mathrm{k} \mathrm{e} \mathrm{m} \mathrm{i} \mathrm{a} \mathrm{n} \mathrm{u} \mathrm{(Fig.} \mathrm{(6)} \mathrm{in} \mathrm{the} \mathrm{30.} \mathrm{segment),} \mathrm{continued} \mathrm{into} \mathrm{loops} \mathrm{between}$ the epidermic cells (Fig. 14, 15). The contractile dorsal vessel, hearts and commissures of segments 9 and 10 produce the current of the blood. Also the other larger vessels are contractile, but they show no rhythmic pulsations.

The contractile commissures (Fig. 17) and the hearts (Fig. 18) consist of an inner layer of longitudinal muscle fibres covered with ring muscle cells. The former are without nuclei in full-grown animals. The sarcoplasm of the circular muscle cells (Fig. 17 B) is differentiated into prismatic columns with a granulated inner $(g)$ and a vesicular outer part (v): their big nucleus ( $n$ ) lies on the outer side, the nuclei of the successive cells forming a slightly undulated row (Fig. $17 \mathrm{~A}$ ). The type of these muscle cells is nematoid.

The intestinal blood-plexus is schizocoelic, not intra-epithelial (Vejdovsky, L. Dehorne), as it is limited by the basement membrane of the chloragogen cells or by the circular splanchnic muscles. In both cases the limit is derived from the coelom wall (splanchnopleure). The pillars that traverse the plexus in certain regions of $P$ elos colex e velin a e (Fig. 2I) and Limnodrilus hoffmeisteri f. divergens (Fig. 19-20). are prolongations of gut-cells. They are not, as in $L u m b r i c u l u s$ (v. Haffner 1927. p. 35) produced by peritoneal cells. Tangential sections (Fig. 20) show the checkered arrangement of the plexus caused by the longitudinal and circular muscle-fibres.

A schizocoelic origin of the circulatory system in Oligochaeta (Lang) can be admitted only theoretically. The ontogeny of $T u b i f$ e $x$ (Penners 1923, t. 14 f. 28, 29) and $\mathrm{L} i \mathrm{~m} \mathrm{n} \circ \mathrm{d} \mathrm{r}$ i I u s (Fig. 22) proves that the ventral vessel develops earlier than the intestinal plexus and therefore cannot be derived from the latter. Similar cases have been described and do not seem to require re-examination, as v. Haffner claims (1927, p. 34). If the schizocoelic plexus is maintained as the origin of the circulatory system in Annelids, its retarded formation in $\mathrm{Tub}$ if ex $\mathrm{Limnodrilus}$ and others must be considered a cenogenetic phenomenon, but if exceptions show to be too numerous, such an opinion is difficult to support. 
In the huge ovaries of $\mathrm{Li} m \mathrm{~m} \circ \mathrm{d} \mathrm{ri}$ I us the oogonia divide into oocytes that during the first period grow solitarily. Only relatively few of them enter the second growth period, in which they are nourished by follicle-cells of peritoneal character. Dorso-ventral strands of mesenteric tissue that pass through the peripherical regions of the ovary give rise to these follicle-cells. As Loewenthal (1922) has shown in $T u$ b i $f$ e $x$ there is also in $\mathrm{Limnod} r \mathrm{i} / \mathrm{us}$ no confluence of nuclei and cytoplasms of several oocytes during growth (Oschmann). The majority of the oocytes degenerates, but there is no sign that they first serve as nutritive cells. The oocytes are basichromatic as long as they are fixed to the ovary; they turn oxychromatic as they move into the ovisac. There they continue to grow, taking up the material provided by the loops of the commissural vessels of the 11. segment and begin the first maturation division.

The only species of the genus $T u b$ if e $x$ hitherto known from South America is T. I a c u stris Cern., found in the sub-littoral and deep zone of Lake Titicaca. That species has a somewhat doubtful generic position, as it shows traces of various genera. It is a "collective type" and such are generally more truly ancient than the so-called primitive" types, the original primitiveness or secondary simplification of which often is discussed. The isolation of the altiplano of Lake Titicaca since the Miocene is reflected in the structure of $T$. I a c u s $+r$ is The finding of the vastly distributed $T u b$ if e $x+u b$ if ex (Fig. 27-29) in two suburbs of the city of São Paulo contrasts with that of the first south-american T u b i $f \mathrm{e} x$ In the two collections of limnic Oligochaeta from the same fluvial system (Cordero 1931, Cernosvitov 1937) T u b ife $x+u b i f e x$ is not listed. This lets us think that the occurrence of $T$. t. in São Paulo is possibly due to an occasional introduction with ornamental fishes or such of economic importance (carp). As the fresh waters in the city and surroundings are by the Sanitary Service stored with fishes to fight the mosquitolarvae, these waters are unequally rich in limnic Oligochaeta. Therefore our few collections do not suffice to state that the occurrence of $T$. $t$. is indeed an isolated fact, as it seems now. The animals are relatively small (up to $40 \mathrm{~mm}$.) with cocoons containing no more than 5 eggs, but morphologically they agree perfectly with european specimens.

Bothrioneurum pyrrhum n. sp., has an unpaired male pore and penial setae (Fig. $30 \mathrm{C}$ ) somewhat different from those of $B$ $v e j d o v s k$ y a n m Sensorial cutaneous papillae do not occur in the new species. Among several hundreds of individuals only 10 showed reproductive organs (Fig. 32,33); the testes lie in the 8. and the ovaries in the 9. segment. This position is somewhat like that found in certain species of A u lod rilus It justifies the separation of the new species, though 
the description of the central-african species mentioned by Cernosvitov (1939, p. 98) could not yet be compared. Two specimens out of the 10 had the gonads partially doubled, so that also the 7. segment was included in the genital region. Irregularities in the position of the reproductive organs are also known in B i ris; this character together with others, viz. the architomy in $B$. $v$ e jdovs $k$ y a n u m the setal muscles of the first segment in B. i r is the absence of spermathecae in all species, the interrupted and chiefly southern geographical distribution and perhaps also the prostomial sensory pit impute a somewhat primitive position to the genus $B$ othrion eurum

B pyrrhum has profusely developed cutaneous vessels (Fig. 31) which originate from the dorsal vessel runining on the left side of the intestine, and which follow the muscular bundles. The worms divide architomically.

Only one cocoon (Fig. 34) with a single egg was seen.

Bothrione urum iris Bedd. was found in a pond near the city of São Paulo. Details of the reproductive apparatus (Fig. 36, 37) and the anterior region (Fig. 38) are described.

A rchigetes si e bold i Leuck., previously known from Europe (see Wisniewski 1930, p. 80-82). North America (Hunter 1930, p. 144) and Japan (Motomura 1929), was found in $L i m n \circ d r i l \mu s$ hof $f$ $m e i s t e r i$ forma $p a r v a$ and $L$ u dekemians from Säo Paulo. A short description is given, and the principal literature is discussed. The four worms taken by Szidat (1937) in a tench do not seem to be further developed (plerocercoid) stages of $A$. s $i$ e b $\circ I d i$. but only procercoids that had lost their tails by mechanical means. Their fixation does not indicate localization in the "right host" as A r c h i ge $t$ e $s$-procercoids isolated on a slide also fix themselves with the bothria. Szidat noted differences in the development of his four parasites found in one tench. Such differences are common among the specimens (up to four) found in one $L i m n \circ d r i l u s$ If $A r c h i g e t e s$ procercoids do develop to $B \mathrm{i}$ a c e t a b u I u $\mathrm{m}$-like stages, what is not yet proved, the latter genus must be dropped and not the first. Till now the excretory system and the scolex are described as different in the two genera. A plerocercoid (=definitive) stage of $A$. b $r$ a $c h$ y u $r$ u s Mraz. is not known. It is precipitated to place this species in the genus $B r a c h$ y u rus (Szidat 1938), besides the generic name Brachyurus is pre-oceupied.

We consider, with Fuhrmann (1931) and others, Arch i getes to be a neotenic procercoid and the other Caryophyllaeidae as neotenic plerocercoids. A species as Glaridacris limnodrili Yamaguti is ecologically (in $L i m n \circ d r i$ I $u$ s) a procercoid, somatically (without tail) it is a plerocercoid, and sexually it is an adult tape-worm. 


\section{H. Literatura}

ALSTERBERG, G. 1922, Die respiratorischen Mechanismen der Tubificiden. Eine experimentell-physiologische Untersuchung auf oekologischer Grundlage. Lunds Universitets Aarsskrift N. F. Avd. 2 v. 18 n.: I, 175 p. 41 f. Lund (citado segundo Zool. Ber. v. 5, p. 505).

- 1924. Die Sinnesphysiologie der Tubificiden. Eine experimentelle Untersuchung mit besonderer Berücksichtigung der respiratorischen Mechanismen. Lunds Universitets Aarsshrift, N. F. Avd. 2 vi 20 n. 7, 77 p. 15 f. Lund (citado segundo Zool. Ber. v. 5, p. 507).

ALTMAN, L. C. 1936, Oligochaeta of Washington. Univ. Washingt. Publ. Biol. v. 4, n.* I, p. I-137 t. I-16. Seattle. Wash.

ANKEL, W. E. 1933, Ei und Eibildung. Handwörterbuch d. Naturwissensch. 2: ed. v. 3. p. 7-36. Jena (G. Fischer).

BALLOWITZ, E. 1890, Untersuchungen über die Struktur der Spermatozoen, etc. Die Spermatozoen der Insekten (I. Coleopteren). Zeitschr. wiss. Zool. v. 50, p. 317-407 t. 12-15. Leipzig.

BEDDARD, F. E. 1895, A monograph of the order of Oligochaeta. XII + 769 p. 5 t. Oxford (Clarendon Press).

- 1896, Naiden, Tubificiden und Terricolen. Ergebn. Hamburg. Magalhaensische Sammelreise v. I, p. 1-62, I t. Hamburg.

- 1901, On a Freshwater Annelid of the Genus Bothrioneuron obtained during the "Skeat Expedition' to the Malay Peninsula. Proc. Zool. Soc. London 1901 v. I. p. 81-87 f. 8-10. London.

BENHAM, W. B. 1903, On some new species of aquatic Oligochaeta from New Zealand. Proc. Zool. Soc. London 1903, part 2, p. 202-232 t. 24-26. London.

BRODE, H. S. 1898, A Contribution to the Morphology of Dero vaga. Journ. Morphol. v. 14, p. 141-180 t. 13-15. Boston.

CERNOSVITOV, L. 1928, Die Oligochaetenfauna der Karpathen. Zool. Jahrb. Syst. v. 55, p. $1-28$ t. I. Jena.

- 1935, Oligochaeten aus dem tropischen Süd-Amerika. Capita Zoologica v. 6. p. 1-36, t. I-6. s'Gravenhage (nāo visto por nós, citado segundo Biol. Abstr. v. II n." I. p. 230$)$.

- 1936, Oligochaeten aus Südamerika. Systematische Stellung der Pristina flagellum. Zool. Anz. v. 113 fasc. 3-4, p. 75-84. Leipzig.

- 1937. Notes sur les Oligochoeta (Naididées ef Enchytraeidées) de I'Argentine. Anal. Mus. Argent. Cienc. Natur. v. 39 (1937-1938), p. 135-157. Buenos Aires.

- 1938, The Oligochaeta. Report of the Percy Sladen Trust Expedition to Lake Huleh; a Contribution to the Study of the Fresh Waters of Palestine. Ann. Mag. Nat. Hist. ser. 11 v. 2, p. 535-550. London.

- 1939. Oligochaeta. The Percy Sladen Trust Exped. Lake Titicaca. Transact. Linn. Soc. London ser. 3 v. 1 part 1, p. 81-116. London.

CLAPAREDE, R. E. 1863. Anneliden. I. Oligochaeten, p. 24-26. Beobachtungen über Anatomie und Entwicklungsgeschichte wirbelloser Thiere. VIII + 120 p. 18 t. Leipzig.

CORDERO, E. H. 1931, Notas sobre los Oligoquetos del Uruguay (primeira serie). Anal. Mus. Nac. Hist. Nat. v. 36 (1929-1931), p. 343-357. Buenos Aires. 
DAUSEND, K. 1931, Ueber die Atmung der Tubificiden. Zeitschr, vergl. Physiol. v. 14 fasc. 3. p. 557-608. Berlin.

DEHORNE, L. 1916, Les Naidimorphes ef leur reproduction asexuée. Arch. Zool. Expér. Génór. v. 56 fasc. 2, p. 25-157 t. 1-3. Paris.

DITLEVSEN, A. 1904, Studien an Oligochaeten. Zeitschr. wiss. Zool. v. 77, p. 398-480. t. 16-18. Leipzig.

DIXON, G. C. 1915, Tubifex. Liverpool Marine Biol. Comm. Mem. 23, 100 p. 7 t. Liverpool (não visto por nós, citado segundo Welsh 1921, p. 201).

EWER, D. W. 1941. The Blood Systems of Sabella and Spirographis. Quart. Journ. micr. Sci. n. ser. v. 82 part 4, p. 587-620. London.

FAULKNER, G. H. 1930, The anatomy and the histology of bud-formation in the Serpulid Filograna implexa, together with some cytological observations on the nuclei of the Neoblasts. Journ. Linn. Soc. London Zool. v. 37 n. 251 , p. 109-190 t.7-8. London.

FREUDWEILER, H. 1905, Studien über das Gefässsystem niederer Oligochäten. Jen. Zeitschr. Naturwiss. v. 40 (neue Folge v. 33), p. 383-422 t. 12-13. Jena.

FRIEND, H. 1911, New records for British Annelids. The Naturalist 1911, n. 659, p. 411-417. London.

- 1912, British Tubificidae. Journ. Roy. Micr. Soc. (June 19/2), Transact. of the Soc., p. 265-293. London.

FUCHS, K. 1907, Die Topographie des Blutgefässsystems der Chätopoden. Jen. Zeitschr. Naturwiss. v. 42 , p. $375-484$ t. 26-28. Jena.

FUHRMANN, O. 1931, Cestoidea. W. Kükenthal \& Th. Krumbach, Handb. Zool. v. 2, 1." metade, p. 141-416 f. 176-435. Berlin \& Leipzig.

GARSTANG, W. 1929. The Morphology of the Tunicata, and its bearing on the Phylogeny of the Chordata. Quart. Journ. micr. Sci. n. ser. v. 72, p. 51-187. London.

GATENBY, J. B. 1915, The Development of the Sperm Duct, Oviduct and Spermatheca in Tubifex rivulorum. Quart. Journ. micr. Sci. n. ser. v. 61, p. 317-336 t. 24. London.

GOODRICH, E. S. 1895, On the Coelom, Genital Ducts, and Nephridia. Quart. Journ. micr. Sci. n. ser. v. 37, p. 477-510 t. 34-35. London.

GRUBER, A. 1881, Zur Kenntnis des Archigetes Sieboldi. Zool. Anz. v. 4, p. 89-91. Leipzig.

HAFFNER, K. v. 1927, Untersuchungen über die Morphologie und Physiologie des Blutgefässsystems von Lumbriculus variegatus Müll. Zeitschr. wiss. Zool. v. 130 fasc. I-2, p. I-82 t. 1-4. Leipzig.

HATAI, S. 1899, On Limnodrilus Gotoi. Annot. Zool. Japon. v. 3 (1899-1901), pars. I (may 31, 1899), p. 5-II t. 2 Tokyo.

HAYEK, G. v. 1877, Handbuch der Zoologie v. I, VI + 513 p. 816 f. Wien.

HEATH, H. 1903. The habits of California Termites. Biol. Bull. v. 4. n. ${ }^{\circ}$, p. 47-63. Lancoster, PA.

HEIDER, K. 1893, Tunicaten, Cap. 35 de E. Korschelt \& K. Heider, Lehrb. vergl. Entwicklungsgesch. wirbellos. Thiere. Spec. Theil, fasc. 3, p. 1266-1428. Jena.

- 1909, Furchung \& Keimblätterbildung. E. Korschelt \& K. Heider, Lehrb. vergl. Entwicklungsgesch. wirbellos. Thiere 1. e 2. ed. Allgem. Theil, fasc. 3, p. 1-470 f. I-321. Jena (G. Fischer).

- 1914, Phylogenie der Wirbellosen. Kultur d. Gegenwart. 3. Teil 4.- Abt. v. 4, p. 453-529 f. 1-25. Leipzig \& Berlin (B. G. Teubner). 
HEIDER, K. 1928, Entwicklungsgeschichte und Morphologie der Wirbellosin. Separata de: Kult. Gegenw. 3. Abtlg. v. 4. (II, 2), p. I-IV, 176-332 f. 1-135. Leipzig \& Berlin. (B. G. Teubner).

HERTER, K. 1925, Tastsinn, Strömungssinn und Temperatursinn der Tiere, etc. Zool. Bausteine v. I fasc. I, p. I-182. Berlin (Gebr. Borntraeger).

HESSE, R. 1893, Beiträge zur Kenntnis des Baues der Enchytraeiden. Zeitschr. wiss. Zool. v. 57 (1894) fasc. I (|2-X||-1893), p. 1.17 t. I. Leipzig.

- 1894, Die Geschlechtsorgane von Lumbriculus variegatus Grube. Zeitschr. wiss. Zool. v. 58, p. 355-362 t. 22 . Leipzig.

- 1894a. Zur vergleichenden Anatomie der Oligochaeten. Zeitschr. wiss. Zool. v. 58, p. 394-439 t. 24-25. Leipzig.

HEUMANN, A. 1931, Vergleichend-histologische Untersuchungen über Geschlechtsorgane: und Clitellum der Regenwürmer. Zeitschr. wiss. Zool. v. 138, p. 515-554. Leipzig.

HOLMGREN, N. 1906, Studien über südamerikanische Termifen. Zoöl. Jatirb. Syst. v. 23 fasc. 5, p. 521-676. Jena.

HRABE, S. 1931, Die Oligochäten aus den Seen Ochrido und Prespa. Zool. Jahrb. Syst. v. 61 fasc. 1-2, p. 1-62 t. I. Jena.

HUNTER, III, G. W. 1930, Studies on the Caryophyllaeidae of North America. Illin. Biol. Monogr. v. II (1927) n.॰ 4, 186 p. II t. Urbana, Illin.

HUXLEY, TH. H. 1875, On the classification of the animal Kingdom. Quart. Journ. micr. Sci. n. ser. v. 15, p. 52-56. London.

IHLE, J. E. W. 1913, Die Appendicularien. Ergebn. Fortschr. Zool. v. 3 fasc. 4, p. 463-534. Jene.

JORGENSEN, M. 1913, Zellenstudien 1. Arch. Zellforsch. v. 10, p. 1-126 t. 1-12. Leipzig. KNOLLNER, F. H, 1935, Oekologische und systematische Untersuchungen uber litorale und marine Oligochäten der Kieler Bucht. Zool. Jahrb. Syst. v. 66 fasc. 6, p. 425-5/2. Jena.

LANG, A. 1903, Beiträge zu einer Trophocöltheorie. $V+373$ p. 6 t. (Tambêm em Jen. Zeitschr. Naturwiss. v. 38). Jena (G. Fischer).

LANKESTER, E. R. 187I, On the Structure and Origin of the Spermatophors, or Sperm-ropes of two Species of Tubifex. Quort. Journ. micr. Sci. n. ser. v. II, p. 180-187 t. 10-11. London.

LASTOCKIN, D. A. 1927, Oligochoeta limicola des Oka-Flusses. Arb. biol. Oka-Stat. v. 5 fasc. I, p. 5-35 t. 1. Murom, USSR.

- 1937. New Species of Oligochaeta Limicole in the european part of the USSR. C. R. Ac. Sci. Moscow n. ser. v. 17 n. 4, p. 233-235 f. 1-2. Moscow.

LEIDY, J. 1852, Descriptions of two new Genero of Vermes. Proceed. Acad. Nat. Sci. Philadelphia v. 5, p. 124-126. Philadelphia.

LEUCKART, R. 1878, Archigetes Sieboldi, eine geschlechtsreife Cestodenamme. Zeitschr. wiss: Zool. v. 30. Suppl., p. 593-606. Leipzig.

LEUNIS, J. \& LUDWIG, H. 1886, Synopsis der Thierkunde. 3:" ed. v. 2, XV+ 1231 p. $1160 \mathrm{f}$. Hannover.

LOEWENTHAL, H. 1922, Die Oogenese von Tubifex tubifex (Müll.). Arch. Zellforsch. v. 16 fasc. 2, p. $231-237$ t. 14 . Leipzig.

LUTZ, A. 1927, Sur ta Schmardaella lutzi Michaelsen. C. Rend. Soc. Biol. Paris, v. 96 fasc. 7, p. 485-486. Paris.

MEHRA, H. R. 1924, The Genital Organs of Stylaria lacustris, with an account of their Development. Quart. Journ. micr. Sci. n. ser. v. 68, p. 147-186 4. 4-5. London. 
MEYER, F. 1915, Untersuchungen über den Bau und die Entwicklung des Blutgefässsyztems bei Tubifex tubifex (Müll.). Vierteljahrsschr. Naturf. Ges. Zürich v. 60, p. 592-596. Zürich (trabolho extenso: 1916, Jen. Zeitschr. Noturw. v. 54).

MICHAELSEN, W. 1900, Oligochaeto. Das Tierreich (Prouss. Akad. Wiss.) fasc. 10 $X X I X+575$ p. Berlin (R. Friedländer \& Sohn).

- 1901, Oligochäten der zoologischen Museen zu St. Petersburg und Kiew. Bull. Acod. Sci. St. Pétersbourg sér. 5 v. 15, p. 137-215 t. 1-2. St. Pétersbourg.

- 1903, Hamburgische Elb-Untersuchung. IV. Oligochäten. Mitteil. Mus. Hemburg v. 19, p. 169-210, 1 t. Hamburg.

- 1903a, Neue Oligochäten und neve Fundorte altbekannter. Mitteil. naturhistor. Mus. Hamburg v. 19, p. $1-54$ t. 1. Hamburg.

- 1905, Zur Kenntnis der Naididao. E. v. Daday, Untersuchungen über die SüsswasserMikrofauna Paraguays. Zoologica fasc. 44, p. 350-36). Stuttgart fnão visto por nós, citado segundo Zool. Record).

- 1909, Oligochaeta. A. Braver, Die Süsswasserfauna Deutschlands fasc. 13, p. 1-66 f. I-II2. Jeno (G. Fischer).

- 1912, Ueber einige zentralamerikanische Oligochoeten. Arch. Naturgesch. Abtlg. A. v. 78 fasc. 9, p. 1/2-129 t. 3. Berlin.

- 1914, Die Oligochaeten Columbios. Voy d'explor. scient. en Colombie. Mém. Soc. neuchât. Sci. nat. v. 5. p. 202-252 t. 8. Neuchätel.

- 1918, Die Lumbriciden, otc. Zool. Jahrb. Syst. v. 41 fasc. 1-3, p. 1-398 t. 1-2. Jeno.

- 1923. Die Oligochaeten der Wolgo. Arb. Biol. Wolga-Stat. (A. L. Behning) v. 7. p. 30-43. Saratov.

- 1925, Zur Kenntnis einheimischer und ousländischer Oligochooten. Zool. Jahrb. Syst. v. 51, p. 255-328. Jena.

- 1926, Schmorotzende Oligochäten nebsł Erörterungen über verwandtschoftliche-Boziehungen der Archioligochäten. Mitteil. Zool. Inst. Mus. Hamburg v. 42, p. 91-103. Hamburg.

- 19260, Schmardaella lutzi Mich., Oligocheoto endoparasitico de Hylidas sul-americonas. Mem. Inst. Oswaldo Cruz v. 19, p. 231-236 (trodução alemã: p. 239-243). Rio de Joneiro.

- 1926b, Oligocheoten aus dem Ryck bei Greifswald, etc. Mitteil. Zool. Inst. Mus. Hamburg v. 42 (1926), p. 21-29. Hamburg.

- 1926c. Zur Kenntnis der Oligochäten des Baikal-Sees. Russ. Hydrobiol. Zeitschr. v. 5 fosc. 7-9, p. 153-174, I t. Saratov.

- 1927. Die Oligochätenfauna Brasiliens. Abh. Senckenb. Naturf. Ges. v. 40 (19251933). p. 369-374. Frankfurt a. M.

- 1927a, Oligochaeta. G. Grimpe, Tierwelt d. Nord \& Ostsee. Fasc. VIc, p. 1-44 f. 1-38. Leipzig (Akadem. Verlagsges.).

- 1928, Oligocheote. W. Kükenthal \& Th. Krumboch, Handb. Zool. v. 2, 2." metode, p. I-118. Berlin \& Leipzig (Wolter de Gruyter).

- 1933. Süss-und Brackwasser-Oligochaeten von Bonaire, ote. Zool. Jahrb. Syst. v. 64 fasc. 3-5, p. 327-350 t. I. Jena.

- 1933a, Ein Panzeroligochaet us dem Beikalsee. Zool. Anz. v. 102 fasc. 11-12. p. 326-333. Leiprig.

- 1935, Oligochäten von Niederländiech-Indien. Arch. Néerland. Zool. v. I, p. 100-117. Leiden. 
MICHAELSEN, W. 1935a, Oligochäten von Belgisch-Kongo. Rev. Zool. Bot. Afric. v. 27 n.' I, p. 33-95. Bruxelles.

MICHAELSEN, W. \& BOLDT, W. 1932, Oligochaeta der Deutschen Limnologischen Sun-

- da-Exped. Arch. Hydrobiol. 1932. Suppl. Bd. IX "Tropische Binnengewässer" v. 2, p. 587-622 t. 12-13. Stuttgart.

MOON, H. P. 1939, The Geology and Physiography of the Altiplano of Peru and Bolivia. Transact Linn. Soc. London ser. 3 v. I part I, p. 27-43. London.

MOORE, J. P. 1905, Some marine Oligochaeta of New England. Proc. Ac. Nat. Sci. Philadelphia, v. 57, p. 373-399 t. 32-33. Philadelphia, PA.

- 1906, Hirudinea and Oligochaeta collected in the Great Lakes Region. Bull. Bur. Fish. (U. S. Dept. of Commerce \& Labor) v. 25 (1905), p. 153-172 t. 32. Washington, D. C.

MOREIRA, C. 1903, Vermes oligochaetos do Brazil. Arch. Mus. Nac. v. 12, p. 125-136. Rio de Janeiro.

MOTOMURA, I. 1929, On the early development of monozoic Cestode, Archigetes appendiculatus including the oogenesis and fertilization. Annot. Zool. Japon. v. 12 n.ं I, p. 109-129 t. 1-4. Tokyo.

MRAZEK, A. 1908, Ueber eine neue Art der Gattung Archigetes. Centralbl. Bakteriol. v. 46 fasc. 8, p. 719-723. Jena.

- 1916, Cestoden-Studien 11. Zool. Jahrb. Anat. v. 39 fasc. 4, p. 515-584. Jena.

NAIR, BHASKARAN K. 1938, On some points in the anatomy of Glyphidrilus annandalei Michaelsen. Zeitschr. wiss. Zool. v. I5I fasc. I, p. 39-74. Leipzig.

NOMURA, E. 1913, On two Species of aquatic Oligochaeta. Journ. Coll. Sci. v. 35 (1913-1915) art. 4, p. 1-49. Tokyo.

- 1915, On the equatic Oligochaete Monopylephorus limosus (Hatai). Journ. Coll. Sci. v. 35 (1913-19|5) art. 9, p. 1-46. Tokyo.

- 1929, On Limnodrilus motomurai. Annot. Zool. Japon. v. 12 (1929-1930) n." I (25-VII-1929), p. |3|-|4| t. I. Tokyo.

- 1932, Limnodrilus grandisetosus, nov. sp. Science Rep. Tôhoku Imp. Univ. Sendai ser. 4 (Biology) v. 7, p. 511-527 t. 13-17. Tokyo.

NYBELIN. O. 1922, Anatomisch-Systematische Studien über Pseudophyllideen. Meddel. Göteb. Mus. zool. avdeln. 16. Kungl. Vet.-Vitterh. Samh. Handl. ser. 4 v. 26. IV +228 p. 118 f. Göteborg.

PENNERS, A. 1922, Die Furchung von Tubifex rivulorum Lam. Zool. Jahrb. Anat. v. 43, p. 323-368 t. 10-11. Jena.

- 1923. Die Entwicklung des Keimstreifs und die Organbildung bei Tubifex rivulorum Lam. Zool. Jahrb. Anat. v. 45, p. 251-308 t. 12-14. Jiena.

- 1933. Ueber Unterschiede der Kokons einiger Tubificiden. Zool. Anz. v. 103 fasc. 3-4, p. 93-95. Leipzig.

PIGUET, E. 1928, Sur quelques Oligochètes de l'Amérique du Sud et d'Europe. Bull. Soc. Neuch. Sci. natur. nouv. sér. v. I (v. 52 de la collection), année 1927, p. 78-101. Neuchâtel.

POINTNER, H. 1911, Beiträge zur Kenntnis der Oligochaetenfauna der Gewässer von Grez. Zeltschr. wissensch. Zool. v. 98 fasc. 4, p. 626-676 t. 28-29. Leipzig.

RANDOLPH, H. 1892, Ein Beitrag zur Kenntnis der Tubificiden. Vierteljahrsschr. Naturf. Ges. Zürich v. 37, p. 145-147. Zürich.

- 1892a, Beitrag zur Kenntnis der Tubificiden. Jen. Zeitschr. Naturwiss v. 27. p. 463-476 t. 17-19. Jena. 
RATZEL, F. 1868, Beiträge zur anatomischen und systematischen Kenntnies der Oligochaeten. Zeitschr. wiss. Zool. v. 18 fasc. 4, p. 563-591 t. 42. Leipzig.

- 1868a, Zur Entwickelungsgeschichte der Cestoden. Caryophyllaeus oppendiculatus Ratzel. Arch. Naturgesch. v. 34, I, p. 138-149 t. 4 f. I-4. Berlin.

- 1869, Histologische Untersuchungen an niederen Thieren. Zeitschr. wiss. Zool. v. 19, p.256-283 t. 22-23. Leipzig.

SMITH, FRANK 1900, Notes on Species of North American Oligochaeta III. List of Species found in Illinois, etc. Bull. III. State Labor. Nat. Hist. v. 5 (1897-19CI), p. 441-458 t. 39-40. Urbana, Illin. 1902.

SOUTHERN, R. 1909, Contributions towards a monograph of the British and Irish Oligochaeta. Proc. Roy. Irish Acad. v. 27B, p. 119-182 t. 7-11. Dublin.

STEPHENSON, J. 1917. Zoological Results of a Tour in the far East. Aquatic Oligochaeta from Japan and China. Mem. Asiat. Soc. Bengal v. 6. p. 83-100 t. 4, Calcutta.

- 1922. On some Scottish Oligochaeta, with a note on encystment in a common fresh-water Oligochaete, Lumbriculus variegatus (Müll.). Transact. Roy Soc. Edinburgh v. 53 part 2, n.' 14 p. 277-295. Edinburgh.

- 1923. Oligochaeta. The Fauna of British India, etc. XXIV + 518 p. 262 f. London (Toylor \& Francis).

- 1929, The Oligochaeta of the Indawgyi Lake (Upper Burma). Rec. Ind. Mus. v. 31. p. 225-239. Calcutta.

- 1930, The Oligochaeta, XVI + 978 p. 242 f. Oxford (Clarendon Press).

- 1931, Reports on an expedition to Brazil and Paraguay, etc. The Oligochaeta. Journ. Linn Soc. London Zool. v. 37 (1930-1932), p. $291-326$ t. 17-18. London.

STERLING, S. 1909, Das Blutgefässsystem der Oligochäten. Jen. Zeitschr. Naturwiss. v. 44 (neue Folge v. 37), p. 253-352 t. 10-18. Jena.

STOLTE, H. A. 193I, Leibeshöhle. Handwörterb. Naturwiss. 2." ed. v. 6, p. 123-138. Jena (G. Fischer).

- 1934, Ueber "selektive" Eibildung bei Stylaria lacustris L. (Blastocytenstudien III). Zeitschr. wiss. Zool. v. 145, p. 79-98. Leipzig.

SZIDAT, L. 1937, Archigetes R. Leuckart 1878, die progenetische Larve einer für Europe neuen Caryophyllaeiden-Gattung Biacetabulum Hunter 1927, Zool. Anz. v. 119 fase. 5-6, p. 166-172. Leipzig.

- 1938, Brachyurus gobii n. g. n. sp., eine neve Caryophyllaeiden-Art aus dem Gründling, Gobio fluviatilis Cuv. Zool. Anz. v. 124 fasc. 9-10, p. 249-258. Leipzig.

UDE, H. 1929, Oligochoeta. F. Dahl, Tierwelt Deutschlands fasc. 15, p. 1-132 f. 1-165. Jena (G. Fischer).

VEJDOVSKY, F. 1876, Ueber Psammoryctes umbellifer (Tubifex umbellifer E. R. Lank.) und ihm verwandte Gattungen. Zeitschr. wiss. Zool. v. 27 fasc. I. p. 137-154 t. 8. Leipzig.

- 1876a, Anatomische Studien an Rhynchelmis limosella Hoffm. Zeitschr. wiss. Zooí. v. 27 fasc. 3, p. $332-361$ t. 21-24, Leipzig.

- 1884, System und Morphologie der Oligochaeten. 116 p. 16 t. Prag. (não visto por nós, citado segundo Beddard 1895, p. 751).

- 1905, Zur Hämocöltheorie. Zeitschr. wiss. Zool. v. 82, p. 80-170 t. 7-11. Loipzig.

- 1907, Zweiter Beitrag zur Hämocöltheorie. Zeitschr. wiss. Zool. v. 85 fasc. I (1906). p. 48-73 t. 4-5. Leipzig. 
VOS. A. P. C. DE 1936, Choetopoda. Flora on Fauna der Zuiderzeo. Supplement, p. 85-96 f. 1-7. Den Helder (nø̃o visto por nós, eitade segunde Zoological Record). WAGNER, F. v. 1890, Zur Kenntniss der ungeschlechtlichen Fortpflanzung von Microstoma Zool. Jahrb. Anat. v. 4 fasc. 3, p. 349-423 t. 22-25. Jena.

WARD, H. B. 1911, The discovery of Archigetes in America, with a discussion of its structure and affinities. Science, new series v. 33, p. 272-273. Now York.

WELSH. P. S. 1921, Bifurcation in the Embryos of Tubifex. Biol. Bull. v. 41 n: 4, p. 188-202. Lancaster, PA.

WESENBERG-LUND. C. 1937, Ferskvandsfaunaen biologisk belyst.' Invertebrata v. I. Costoides Baendelorme, p. 170-198; Oligochaota Regnorme, p. 320-354 t. 10 Köbenhavn (Gyldendalske Boghandel-Nordisk Forlag).

WhLSON. E. B. 1934, The Cell in Development and Heredity. 3.' ed. XXXYH + 1232 p. 629 f. Now York (The MacMillan Company).

WISNIEWSKI, L. W. 1928, Archigetes cryptobothrius n. sp. nebst Angabe über die Entwicklung im Genus Archigetes R. Leuck. Zool. Anz. v. 77 fasc. 3-6, p. 113.124. Leipzig.

- 1930. Das Genus Archigetes R. Leuck. Eine Studie zur Amatemie, Histogenese. Systemotik und Biologie. Mém. Acad. Polen. Scienc. Lettnos, Classe Sci. Mathóm. Natur. Sór. B v. 2, p. 1-160 t. 1-8. Cracovie.

- 1933. Cyathosephalus truncatus Pallas. Bull. Acad. Polon. Scienc. Lettros, Classe Sci. Mathém. Natur. Sér. B, Sci. Nat. (II). p. 237-252 (Die Pestembryonalentwicklung und Biologie). p. 311-327 + 13. (Allgemaine Morphologie). Cracovie.

WOOOLANO. W. N. F. 1923. On some remorkeble new Forms of Caryophyllaeidae from the Anglo-Egyptian Sudan, and a Revision of the Families of the Cestedarie. Quart. Journ. miar. Sci. n. Ser. v. 67. p. 435-472 t. 24-25. London.

- 1926. On the Genere and possible Affinitios of the Caryaphyllaeideo: A Reply to Drs. O. Futhrmepn and J. G. Baer. Proc. Zool. Soc. London 1926. n.ं 1. p. 49-69. London.

YAMAGUTA. S. 1934. Studies on the Helminth Foun of dopan. Part 4. Cestodos of Fishes. Jap. Journ. Zool. v. (1934-36). p. N-112. Tokyo. 


\section{Estampas}




\section{ESTAMPA I}

Peloscolex evelinae, spec. nov.

Fig. I - Parte anterior do corpo (segmentos I-VIII).

Fig. 2 - Cerdas. A, feixe dorsal com a cerda capilar e a minúscula acicular. B, cerda ventral dos segmentos II-V. C, cerda ventral do 6." segmento para trás. D, feixe ventral de cerdas em zona regenerada.

Fig. 3 - Cortes longitudinais do integumento velho (A) e regenerado (B). C, musculatura circular (anelar); e, epiderme; I, musculatura longitudinal; $n$, papila sensorial; s, somatopleura; $t_{1}$ cutícula. 

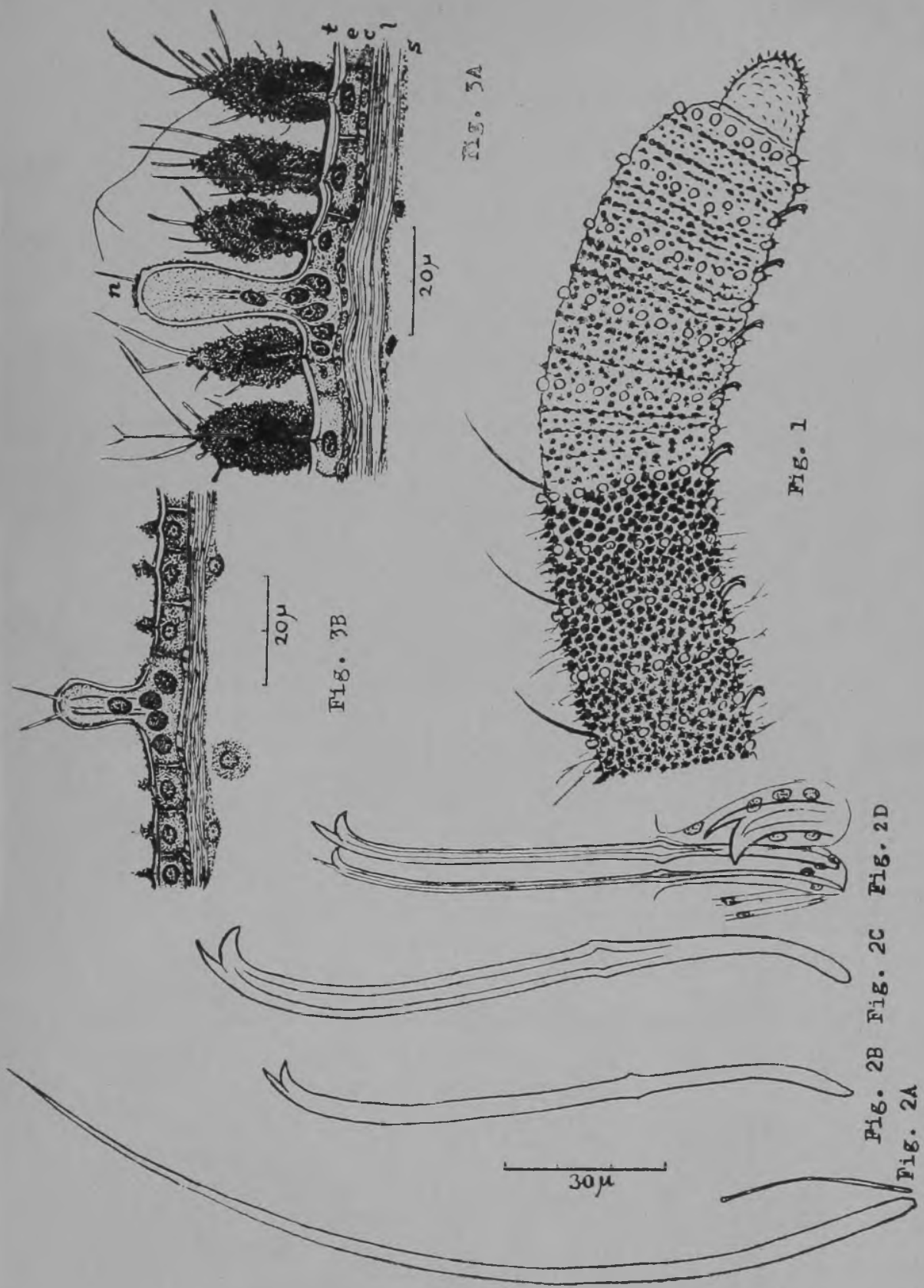


\section{ESTAMPA II}

Fig. 4 - Cerdas de Limnodrilus hoffmeisteri forma parva Southern. $A_{1}$ cerda do $3 .^{\circ}$ segmento; $B_{1}$ cerda do $300^{\circ}$ segmento.

Fig. 5 - Vista dorsal dos segmentos VII-XIV de Limnodrilus

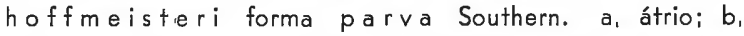
bainha do penis; $c$, coração; $d$, duto masculino; e, sacos espermáticos; $f_{1}$ funíl masculino; $g$, vaso dorsal; $i_{\text {, clitelo; }}$ $n_{1}$ nefrídio; o, ovário; $p_{1}$ próstata; $s$, espermateca; $t$, testículo; u, intestino. O átrio e a próstata foram, pela compressão do preparado, deslocados do 12.' segmento para - 13.0 .

Fig. 6 - Cerdas de Limnodrilus hoffmeisteri Clap. forma divergens f. n. A, cerda ventral do $400^{\circ}$ segmento; $B_{1}$ cerda ventral do $4 .^{\circ}$ segmento; $C_{1}$ cerda dorsal anômala. com ponta accessória (frequente nos segmentos II-V).

Fig. 7 - Cérebro de Limnodrilus hoffmeisteri forma divergens.

Fig. 8 - veja est. III

Fig. 9 - Bainha do penis de Limnodrilus noffmeisteri f. divergens, com os músculos. 


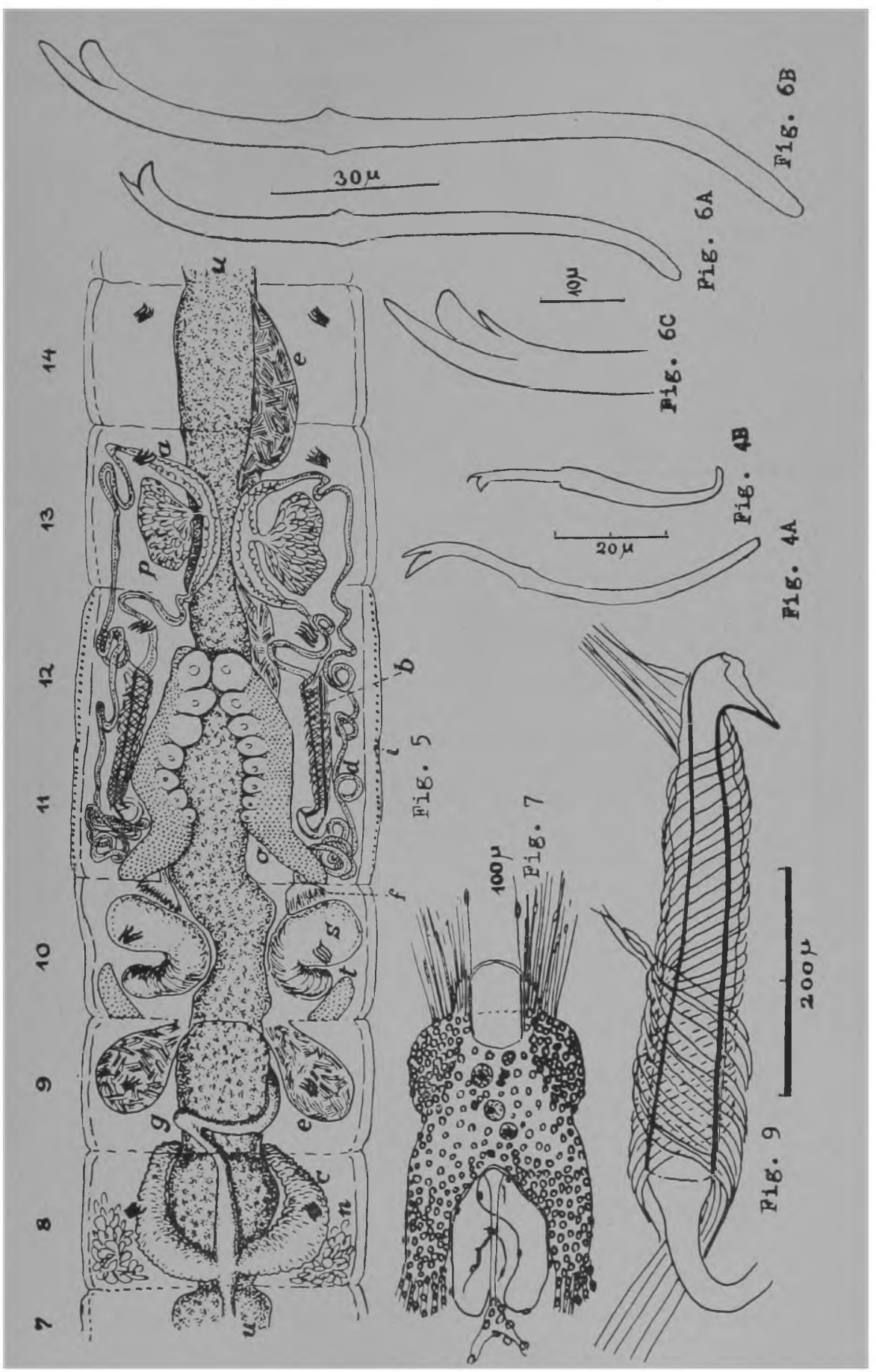




\section{ESTAMPA III}

Fig. 8 - Segmentos VIII-XIII, em vista dorsal, de Limnodrilus hoffmeisteri f. divergens. O intestino $(u)$ e o sistema nervoso $(z)$ em grande parte removidos; nos segmentos $X$ e Xl foram as gônadas do lado esquerdo e os aparelhos auxiliares do lado direito cortados. $a_{1}$ átrio; $b$, bainha do penis; $c$, coração; $d$, duto masculino; e, saco espermático; $f_{1}$ funíl feminino; $g_{1}$ vaso dorsal; $i_{\text {, ovisaco; }}$ $m$, funíl masculino; $n$, nefrídio; o, ovário; $p$, próstata; $r$, músculo retractor do penis; $s$, espermateca; $t$ testículo; $u$, intestino; $z_{1}$ cadeia nervosa ventral. 


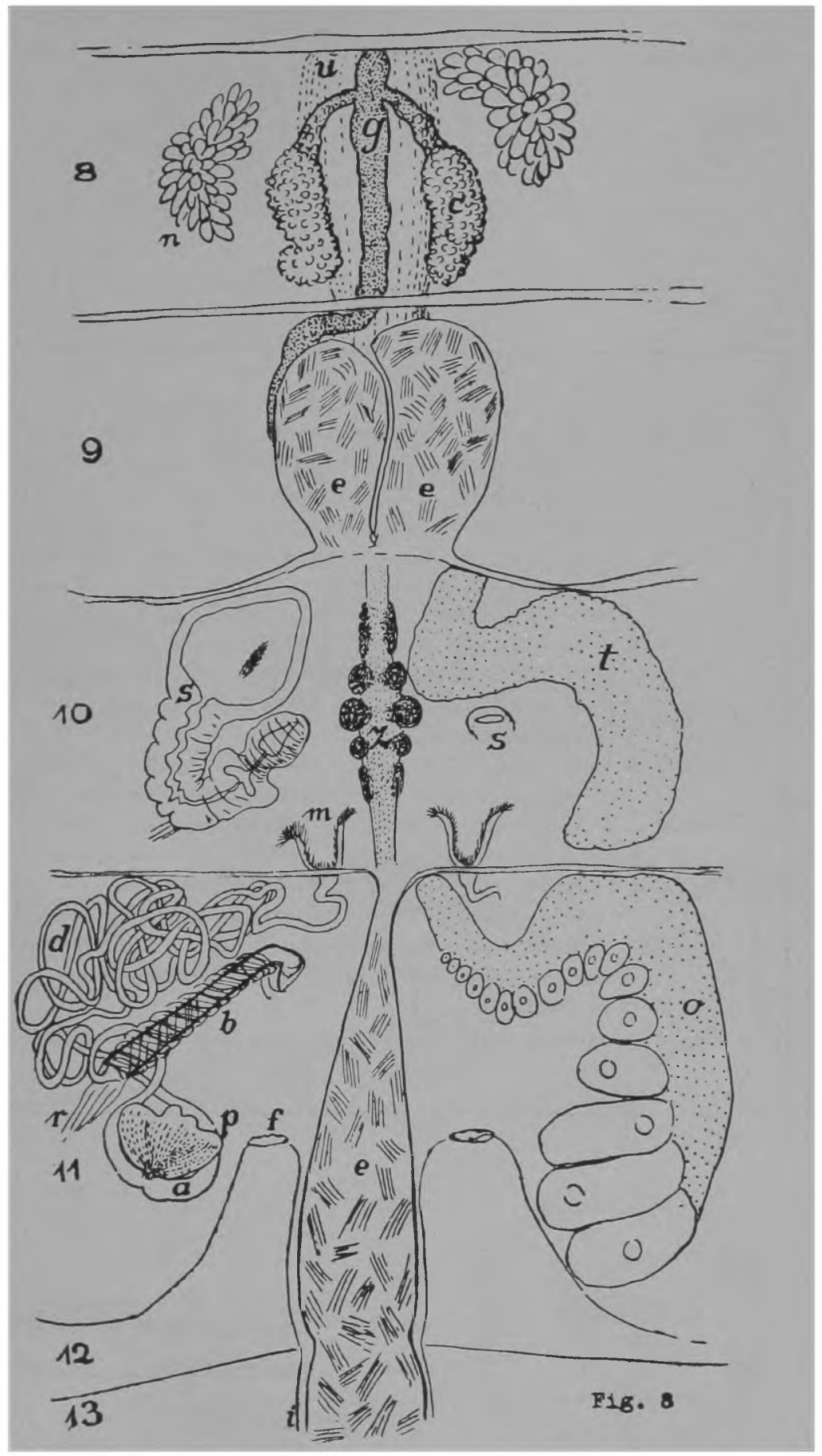




\section{ESTAMPA IV}

Fig. 10 - Limnodrilus udekemianus Clap. A, cerda do 3. segmento: $B$, cerda do $60^{\circ}$ segmento; $C$, bainha do penis.

Fig. 11 - Fig. 14 referem-se a Limnodrilus hoffmeisteri forma divergens.

Fig. II - Vista dorsal dos 10 segmentos anteriores (método de ácido crômico; v. Haffner 1927, p. 28). c. coração: d, vaso dorsal; $i_{1}$ intestino; $n$, nefrídio (revestido por células vesiculosas nos segmentos VII e VIII): o, comissura anterior (celomática): $s$, vaso supra-intestinal.

Fig. 12 - Vista lateral dos segmentos VII e VIII, sem nefrídios. V, vaso ventral; as letras restantes como em Fig. 11 .

Fig. 13 - Vista lateral (A) e esquema transversal (B) dum segmento da metade posterior. a, comissura posterior (cutânea); $\mathrm{m}$, ligamento septo-intestinal; $n$, sistema nervoso ventral; $p$, plexo sanguíneo intestinal; $U$, comissura unilateral; as letras restantes como nas Fig. II e 12. As setas (Fig. 13. A) indicam a direção do sângue nos vasos dorsal e ventral.

Fig. 14 - Pele de quatro segmentos posteriores, cortada na linha mediana dorsal, mostrando os vasos cutâneos e as cerdas.

Fig. 15 - veja est. $V$

Fig. 16 - Rede dos vasos cutâneos de Limnodrilus udeke mianus. 


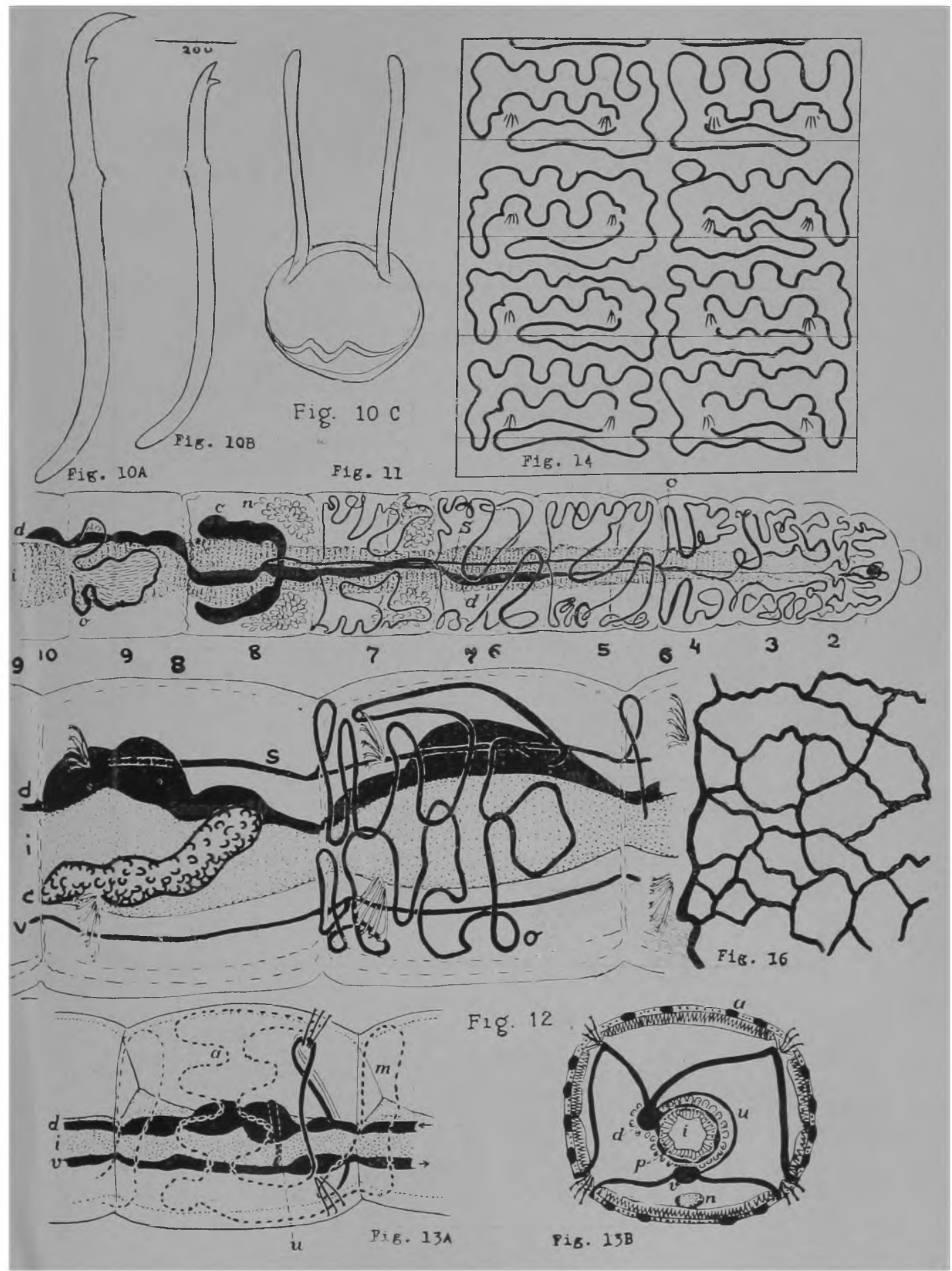




\section{ESTAMPA V}

Fig. 15 - Corte da pele dum dos segmentos posteriores de Limnodrilus hoffmeisteri forma divergens. a, capilares cutâneos; e, epiderme (hipoderme da literatura); s, somatopleura.

Fig. 16 - veja est. IV

Fig. 17 - Comissura contractil do $100^{\circ}$ segmento de $L$, hoffmeisteri f. divergens. A, preparação total; $B$. corte transversal; $C$, esquema. a, amebócito intravascular; $c_{\text {, }}$ fibrilas circulares; g, colunas sarcoplasmáticas granulosas; I, fibrilas longitudinais; $n$, núcleo da célula musculosa circular; $v_{1}$ zonas sarcoplasmáticas vesiculosas.

Fig. 18 - Coração de L. hoffmeisteri f. divergens. A, corte longitudinal; B, corte paratangencial. As letras, como na Fig. 17.

Fig. 19 - veja est. VI.

Fig. 20 - veja est. VI.

Fig. 21 - Corte longitudinal da parede do intestino no $100^{\circ}$ segmento de Peloscolex evelinae, ostentando o indivíduo da Fig. $2 \mid$ A pilares ( $p$ ) mais altos que 0 da Fig. 2।B. c, cólulas cloragógenas; $e_{1}$ epitélio intestinal; $s$, plexo sanguíneo intestinal. 

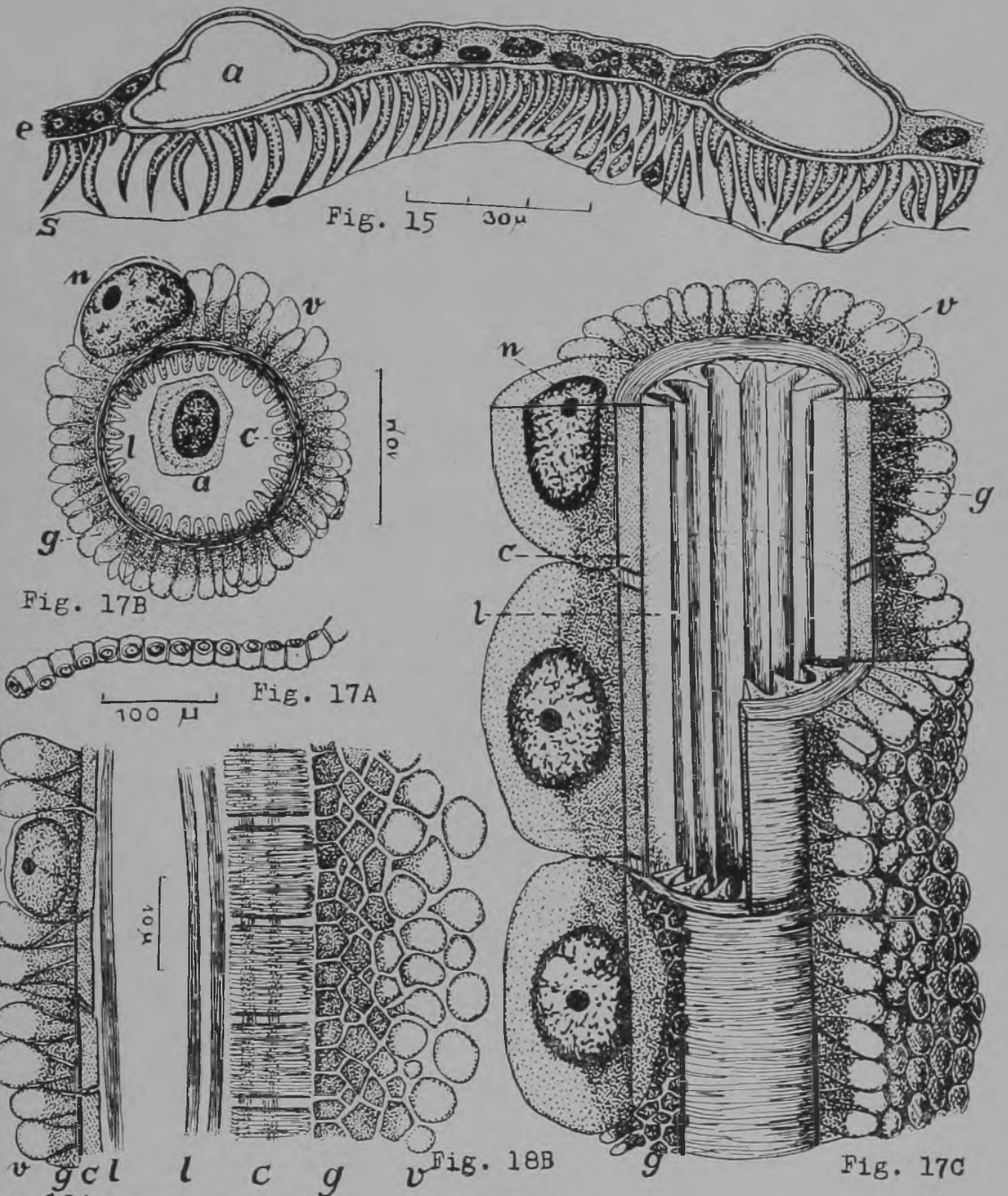

F1g. $18 \mathrm{~A}$
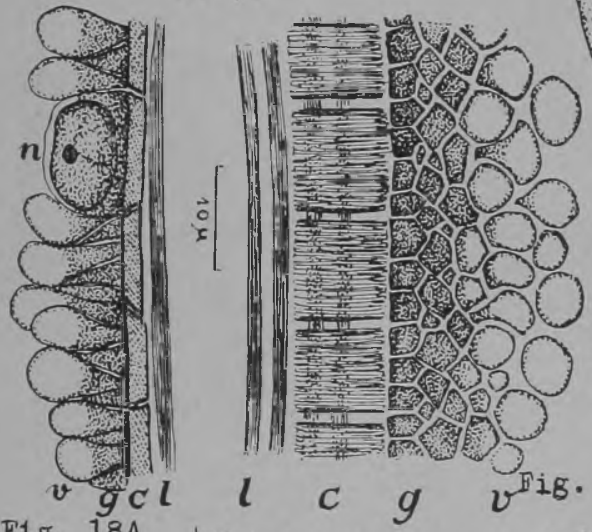

(1) 6.

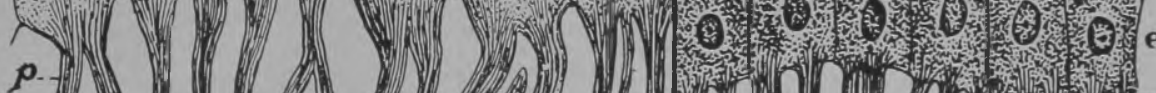

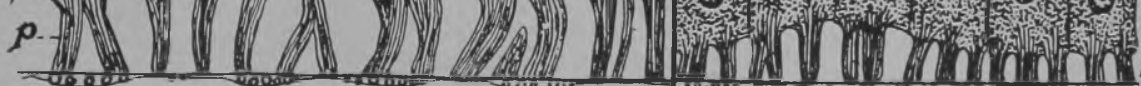

Fiร. $21 \mathrm{~A}$

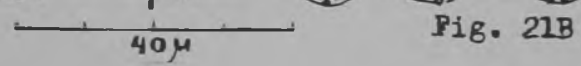




\section{ESTAMPA VI}

Fig. 19 - Corte longitudinal da parede intestinal ventral do $15 .^{\circ}$ segmento de Limnodrilus hoffmeisteri forma divergens. c, células cloragógenas; e, epitélio intestinali $m$, musculatura esplâncnica circulari p. pilar da parede intestinal; $s$, plexo sanguíneo intestinal.

Fig. 20 - Corte tangencial do esôfago no $6 .^{\circ}$ segmento de $\mathrm{Lim}$ nodrilus hoffmeisteriforma divergens.l, musculatura esplânenica longitudinal. As outras letras, como em Fig. 19.

Fig. 21 - veja est. V.

Fig. 22 - Corte transversal dum embrião de Limnodrilus hoffmieisteri forma divergens. e, endoderma; $s_{\text {, }}$

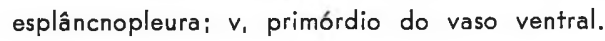

Fig. 23 - Casulo recem-depositado de Limnodrilus hoffmeisteri forma divergens.

Fig. 24 - Casulo recem-depositado de Tubifex tubifex (Mül!.). 


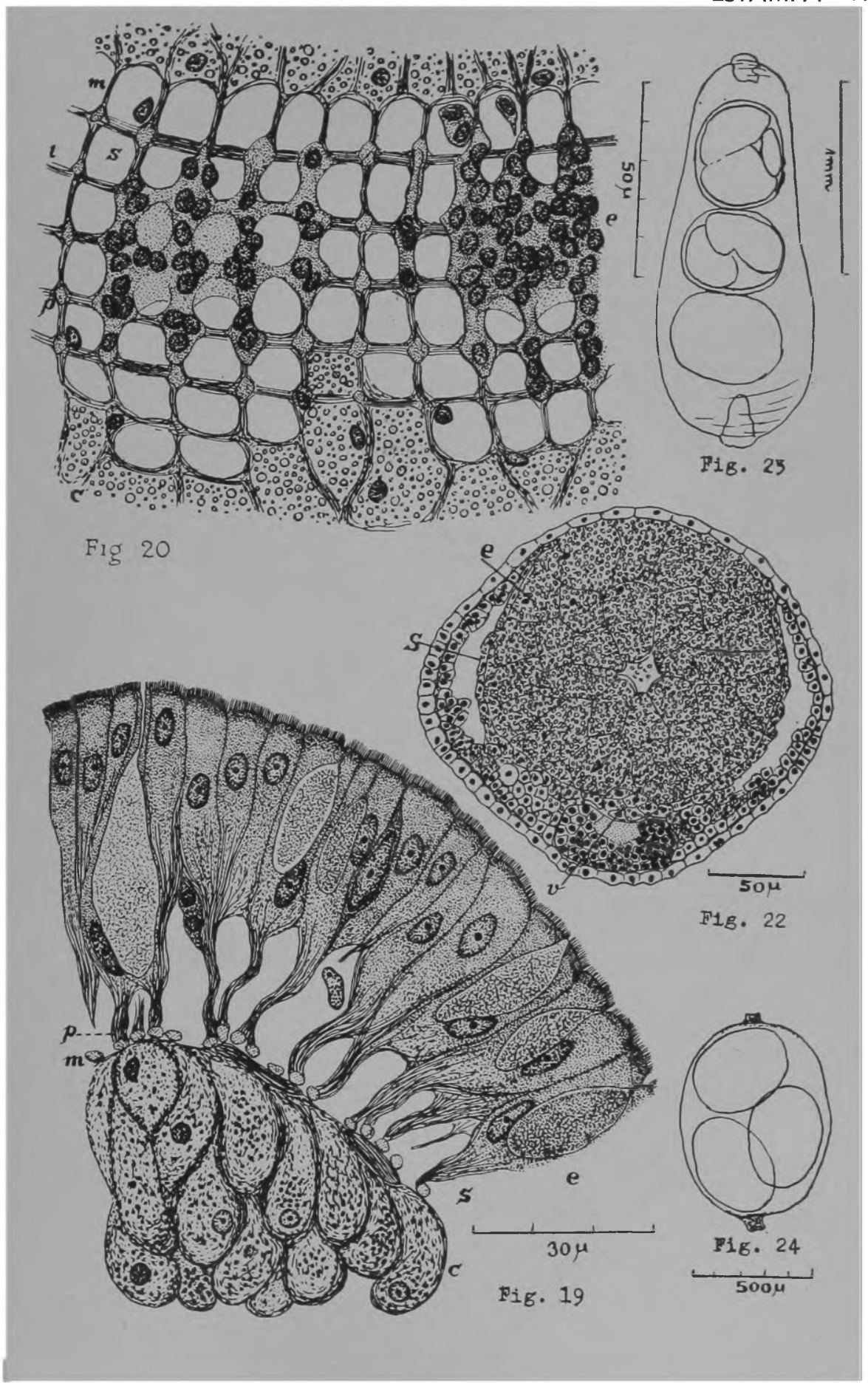




\section{ESTAMPA VII}

Fig. 25 - Esquema da estrutura do duto masculino, numr trecho preatrial (Limnodrilus hoffmeisteri f. parva e f. divergens)

Fig. 26 - Ovário de Limnodrilus hoffmeisteri f. di vergens $A$, topografia dos ovários no $110^{\circ}$ segmento. $B$, zona germinativa (1), de divisão (2) e zona presináptica (3). C, zona de crescimento (4). D, zona de crescimento e de degeneração $(5)$. c c células cloragógenasi $d_{\text {, }}$ duto masculino; e, processo dum oócito no $2 .^{\circ}$ período de crescimento; $f_{1}$ célula folicular; $i$, intestino médio; $m$, metafase da divisão duma oogônia; o, oogônia; $p$, célula peritoneali $v_{1}$ vasosi $s$, oócitos em sinapsis; $z_{1}$ cadeia nervosa ventral. 
FRNESTO MARCUS - Tubificidae do Brasil

(20. $00 \div 0: 0000$

$10019.6 \%$ - 50 \%

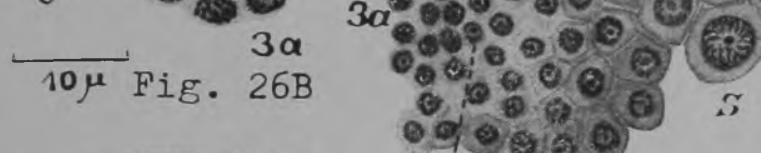

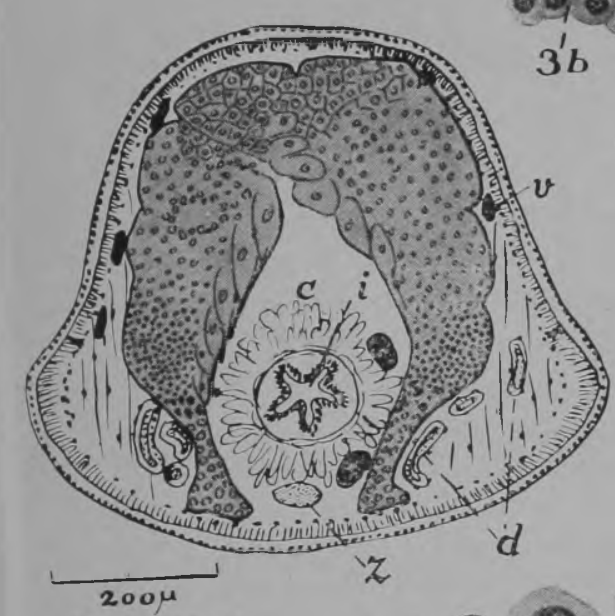

Fig. 26A $00 \% 0^{\circ} \quad 4$

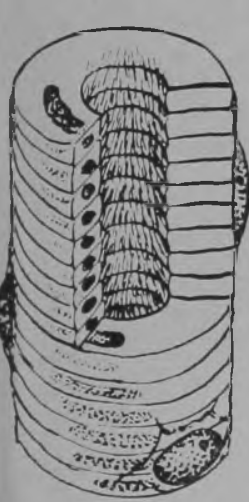

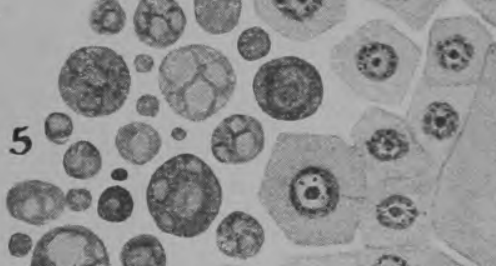
$50 \mu$

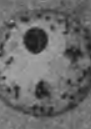

Q

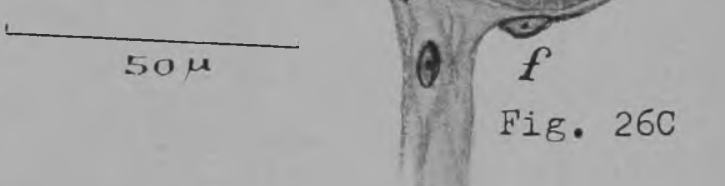

30000 $00^{\circ}, 090$ co 0
(c)
(6) 00
8) Fig. 26D

$\because \because 0$

Fig. 25

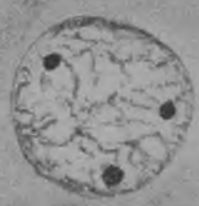

(8) 9

(3) 90

100

$$
\text { (2) } 8000 \text { क }
$$




\section{ESTAMPA VIII}

Tubifex tubifex (Müll.).

Fig. 27 - Cerdas. $A$, cerda ventral do $60^{\circ}$ segmento. B, C, cerdas aciculares dorsais. D, cerda capilar dorsal (parte basal).

Fig. 28 - Topografia do terço anterior em vista dorsal.

Fig. 29 - Segmentos VIII-XIV; vista dorsal (A) e lateral (B). a. átrio; $b$, penis; $c$, coração: $d$, duto eferente; e, espermateca; $f_{1}$ funíl feminino; $i$, infestino (em parte suprimido): $k$, clitelo; $m$, funíl masculino; $n$, orifício da espermateca; $o$, ovário parcial; $p$, próstata; $r$, vaso dorsal; s, óstio do saco espermático; t. testículo: u, ovisaco; v, ovário original. 


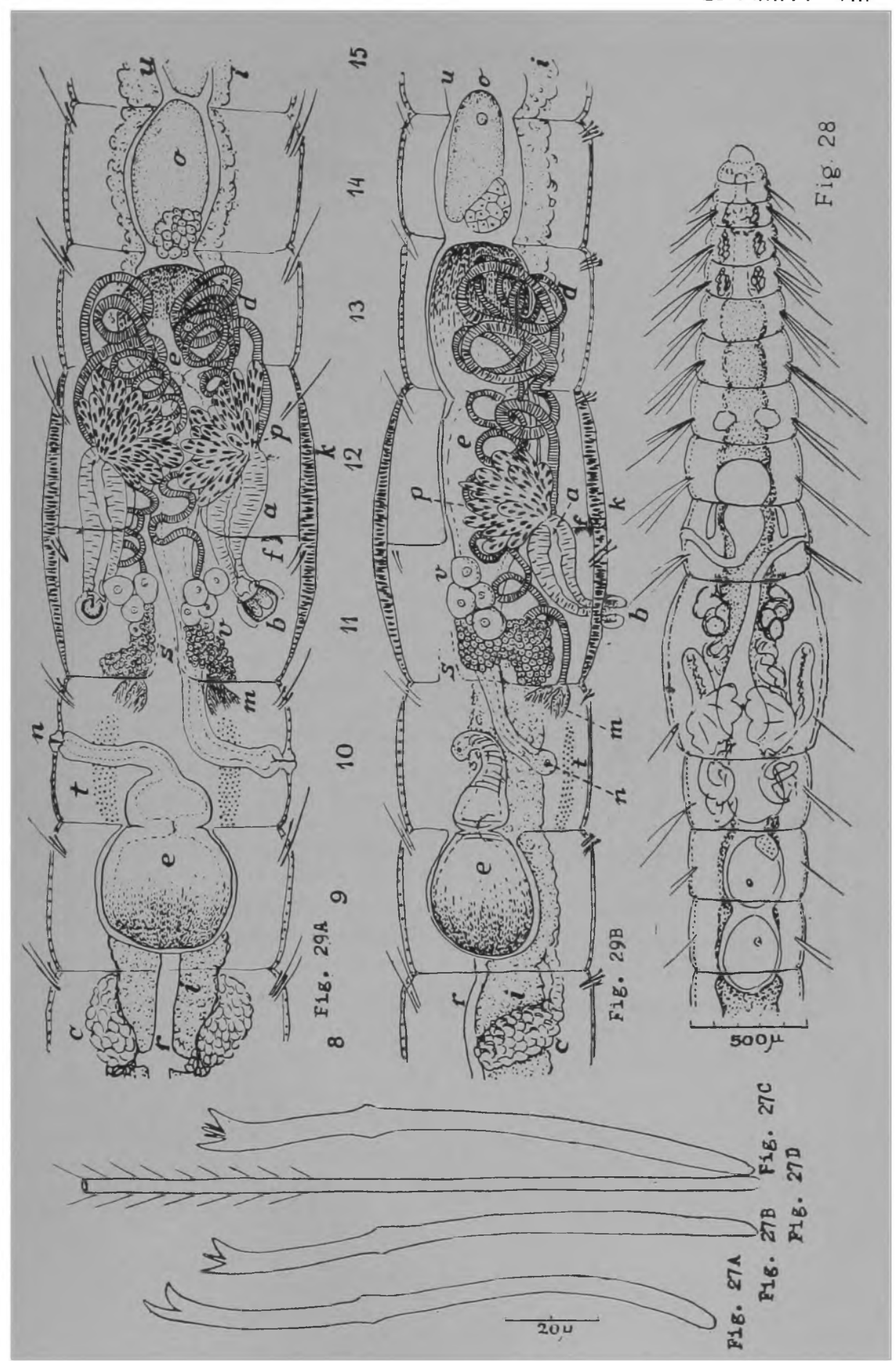




\section{ESTAMPA IX}

Bothrioneurum pyrrhum spec. nov.

Fig. 30 - Cerdas. A, cerda do $3 .^{\circ}$ segmento. B, cerda do $20 .^{\circ} \mathrm{seg}$ mento. $C$, cerda genital (penial).

Fig. 31 - Vasos cutâneos. A, aspeto do lado dorsal dum segmento post-clitelar, vendo-se, pontilhada, a afluência oriunda do vaso dorsal. (não visivel, sito no lado esquerdo do intestino). B, corte longitudinal da pele; os vasos em preto. a, celomócito; c, cutícula; e, epiderme com a camada subjacente da musculatura circulari $I$, musculatura longitudinali $p$, peritôneo (somatopleura); $v$, vaso.

Fig. 32 - Esquema dos órgãos reprodutivos. a, póro masculino; $b$, botão epidérmico; $c_{1}$ clitelo; $d$, duto masculino; $e_{1}$ cerdas peniais; $f_{1}$ funíl feminino; $g$ glândula no trecho post-paratrial do duto masculino; $i$, ovisaco; $m$, funil masculino; $n_{\text {, }}$ saco espermático: $O$, ovário; $p$, parátrio; $r$ massa glandular do trecho pre-paratrial do duto masculino; $s$, grupos de espermatócitos soltos do testículo; $t_{1}$ testículo. 

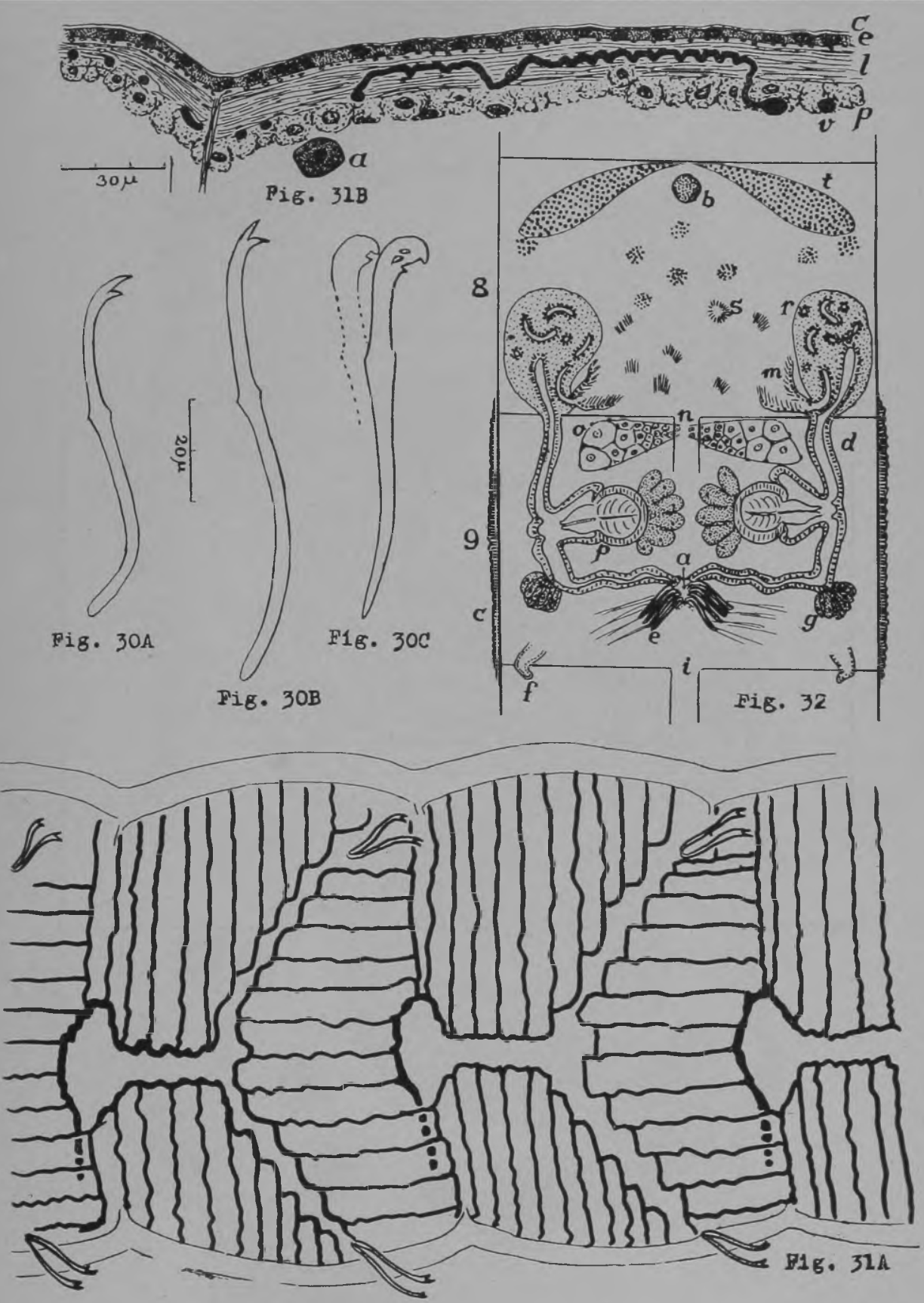


\section{ESTAMPA $X$}

Bothrioneurum pyrrhum spec. nov.

Fig. 33 - Corte sagital (combinado) do $80^{\circ}$ e 9.० segmento dum exemplar maduro. Saco espermático, ovisaco, intestıno, vasos, cadeia nervosa e celomócitos suprimidos. a, póro masculino; $b$, botão epidérmico; $c$, clitelo; $d$, duto masculino: $e_{1}$ cerdas peniais; $f$, funíl feminino; $g$, glândulas postparatriais; $m$, funíl masculino; $o$, ovário; $p$, parátrio: $r$, massa glandular pre-paratriali $s_{1}$ grupos de espermatócitos livres; $t$ testículo; $x$ átrio; $y$, oócito no caminho para o ovisaco.

Fig. 34 - Casulo recem-depositado. 


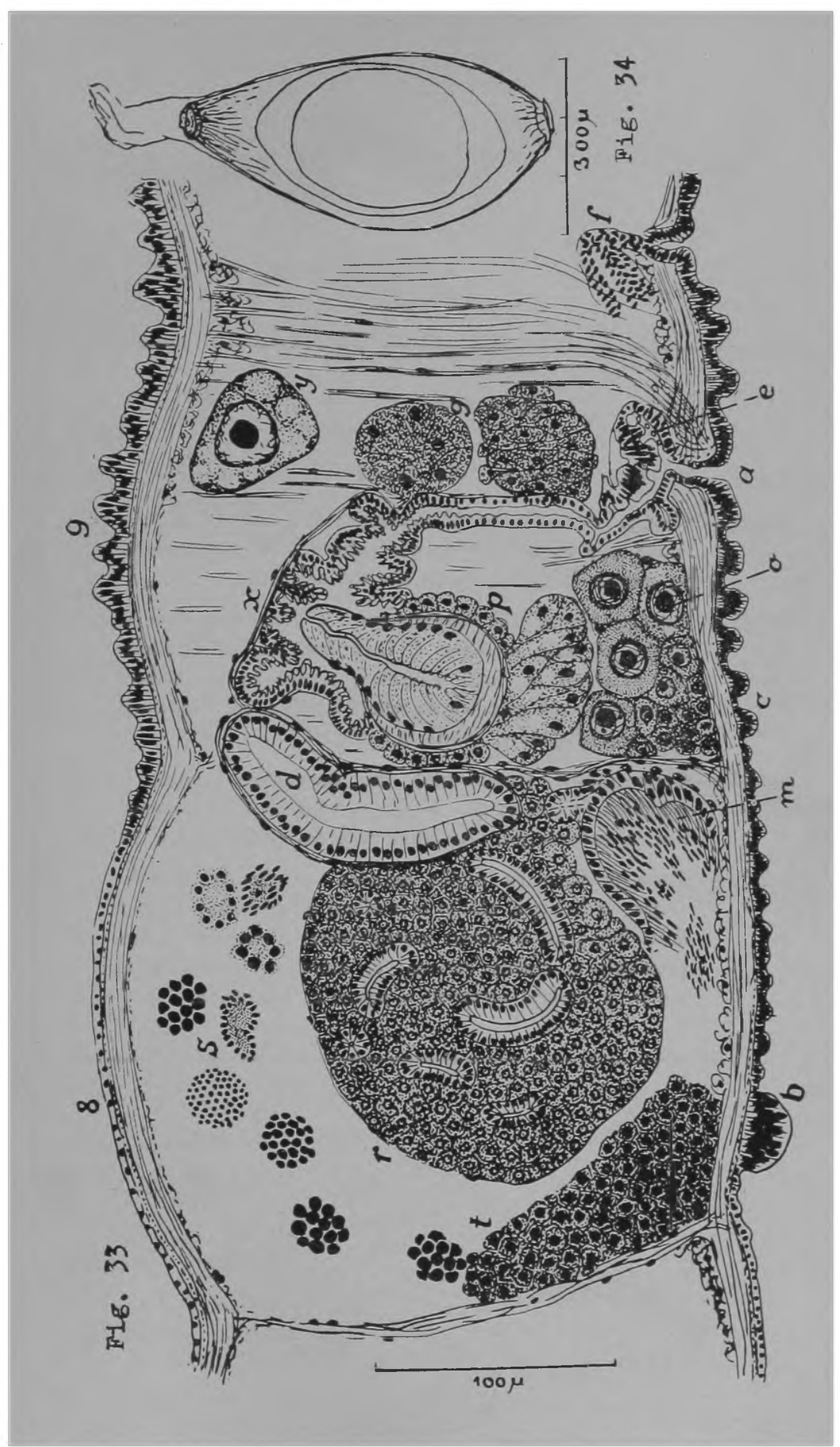




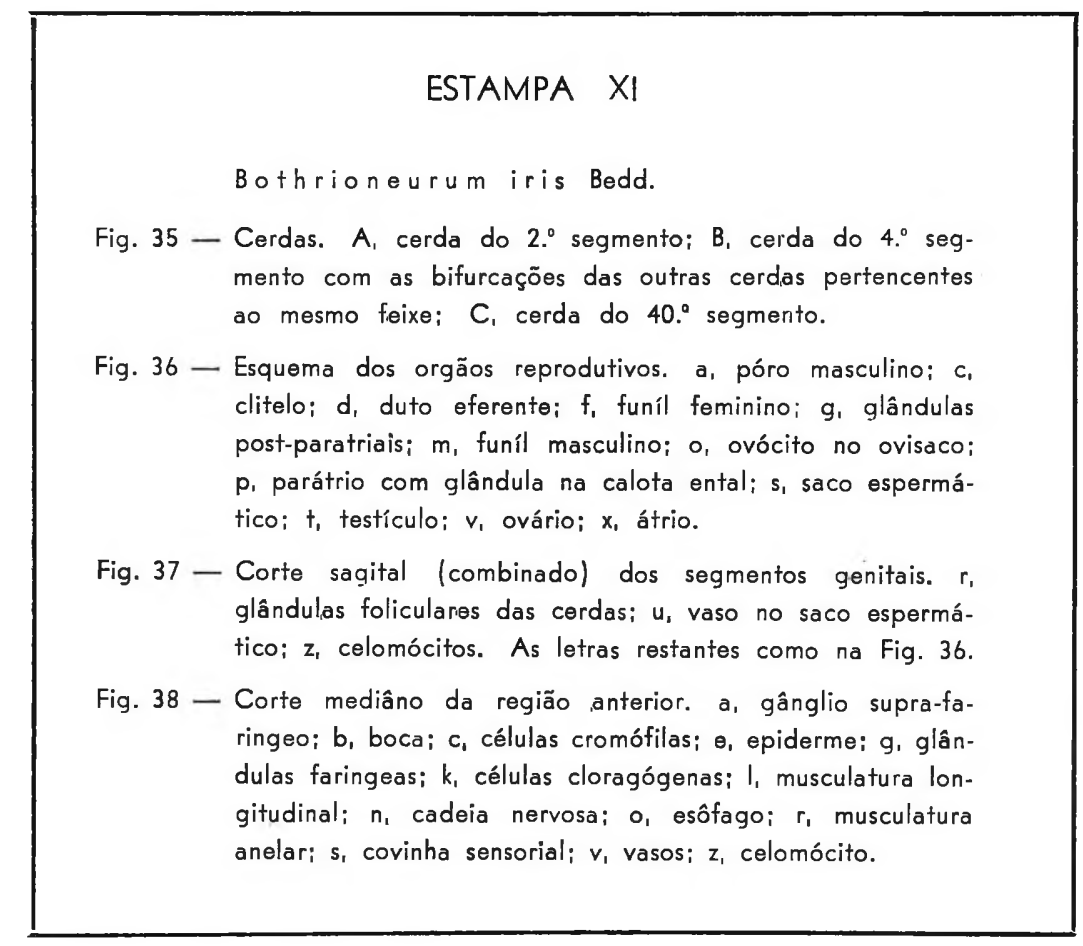




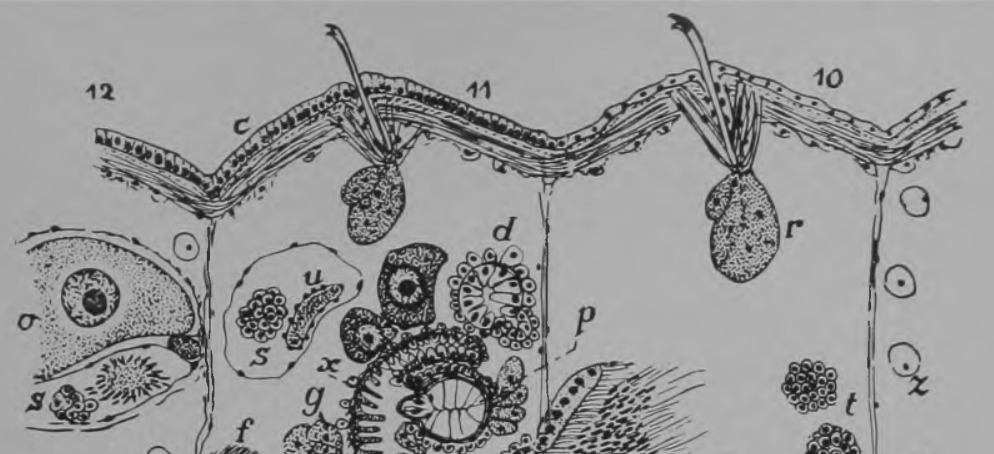

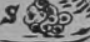

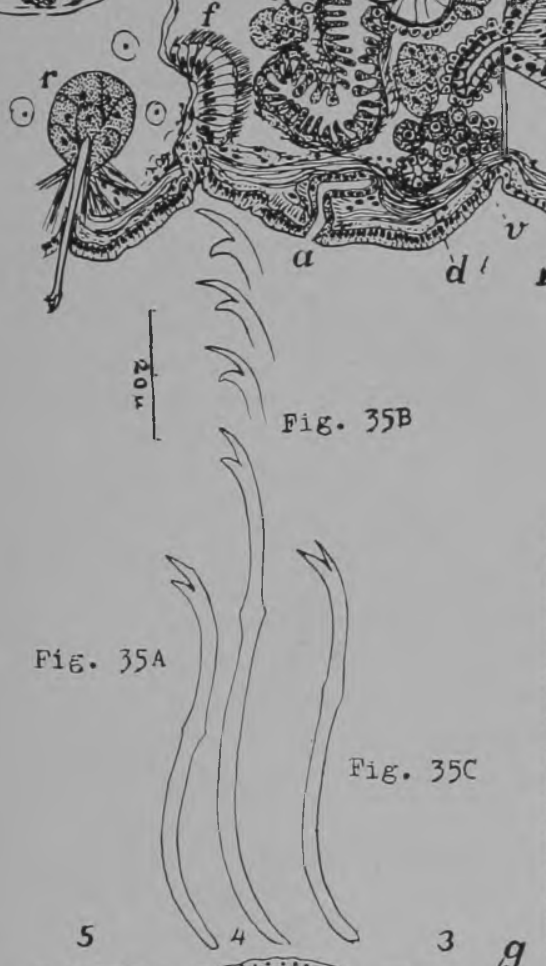

5
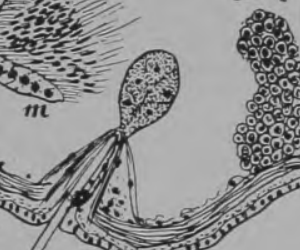

\%ำ
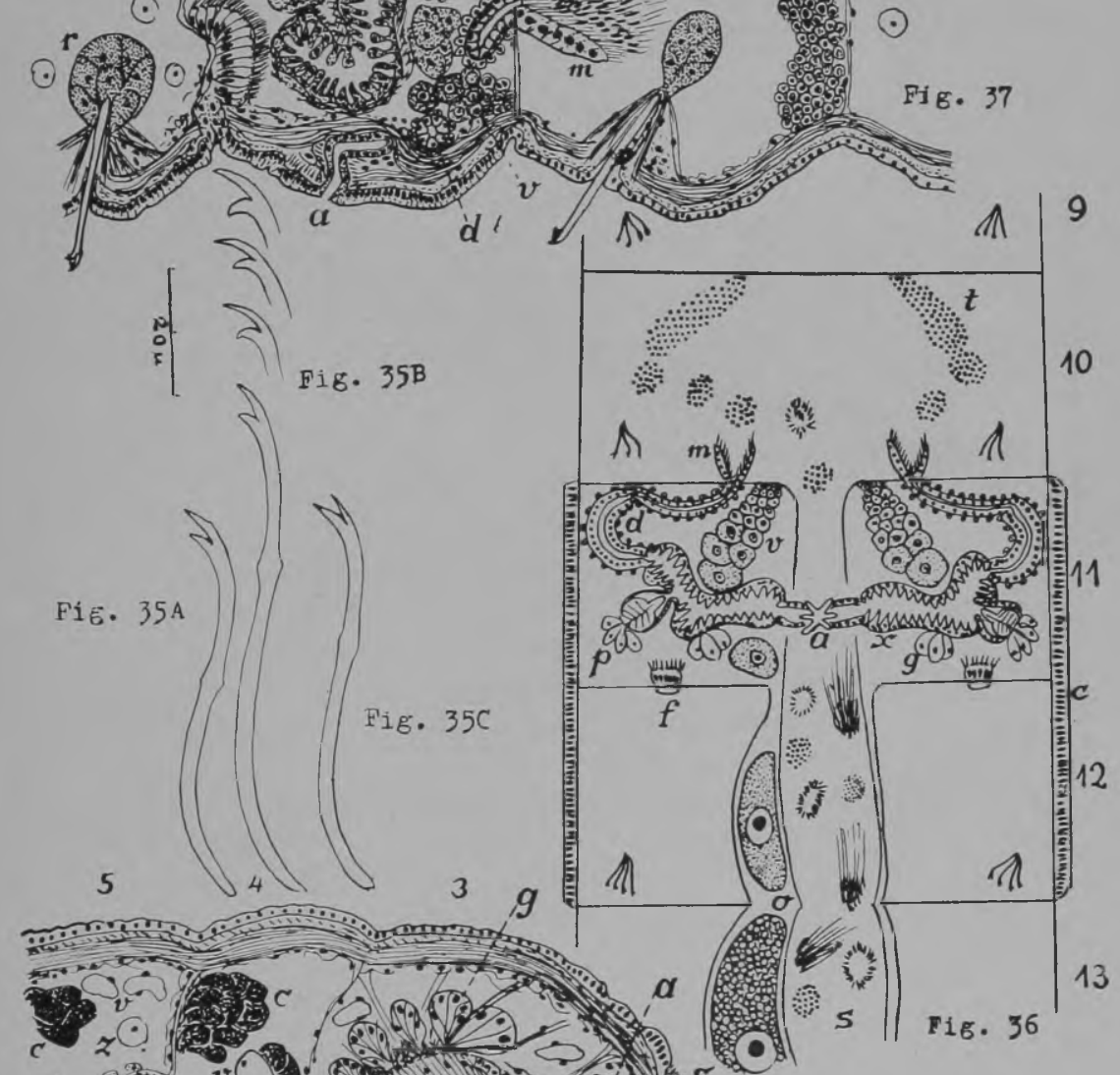

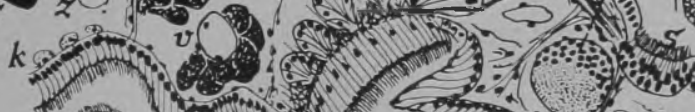
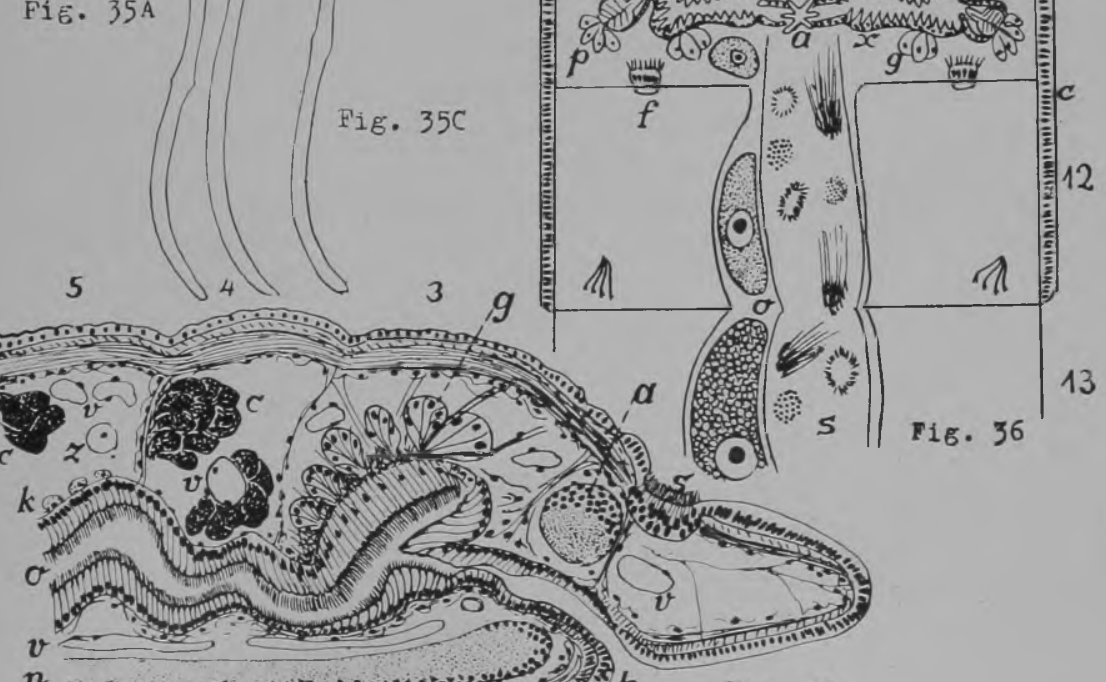

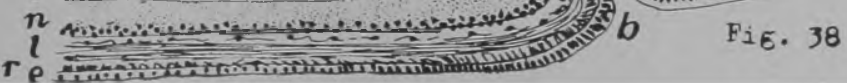




\section{ESTAMPA XII}

Fig. 39 - Limnodrilus udekemianus (segmentos 1-17), vivente, com dois espécimes de Archigetes sieboldi Leuck., um no saco espermático $(s)$ e outro no ovisaco $(0)$. O parasita no saco espermático contem ovos maduros. Letras relativas aos órgãos do hospedador: c, coração; $d$, vaso dorsal, sito, na regiāo em que foi indicado, lateralmente; $t_{1}$ testículo; $v_{1}$ vaso ventral.

Fig. 40 - Indivíduo vivente de Archigetes sieboldi Leuck. $a$, vagina; $b$, bótrio ventral; $c$, bolsa do cirro; $d$, viteloduto; e, células cervicaisi g, ganchinhos caudais; $h$, esfincter no início do oviduto; $i$, oótipo (região glandular do ovi- duto); o, ovário; $p$ póro genital; $s$, vesícula seminal; $t_{\text {, }}$ testículo; $u$, útero; $v_{\text {t }}$ vitelário.

Fig. 41 - Parte cefálica de Archigetes sieboldi estendida e contraida em vista ventral (ou dorsal) e lateral. 


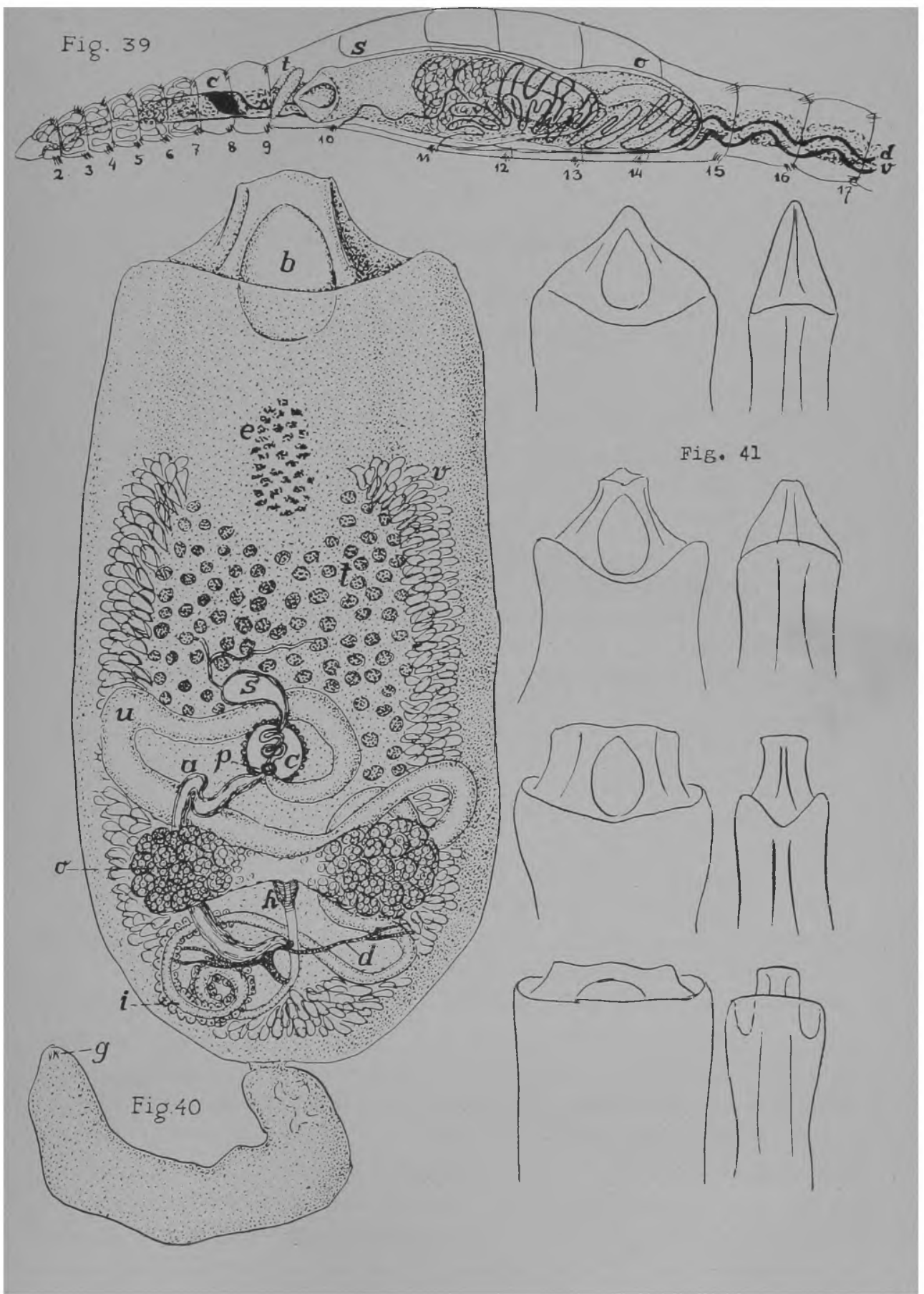

